\title{
EFFECTS OF PRESCRIBED BURNING ON GROUND-FORAGING ANT ASSEMBLAGES
}

A Thesis presented to the Faculty of the Graduate School University of Missouri Columbia

In Partial Fulfillment Of the Requirements for the Degree

Master of Science

By ELIZABETH W. WRIGHT

Dr. Rose-Marie Muzika, Thesis Supervisor

December 2013 
The undersigned, appointed by the Dean of the Graduate School, have examined the thesis entitled

\section{EFFECTS OF PRESCRIBED BURNING ON GROUND-FORAGING ANT ASSEMBLAGES}

Presented by Lizzie W. Wright

a candidate for the degree of Master of Science and hereby certify that in their opinion is worthy of acceptance.

Dr. Rose-Marie Muzika

Dr. Francisco X. Aguilar

Dr. Richard Houseman 
This work is dedicated to Jim Wolfe, Sebastian Jurado and Analuisa Ugalde at the Monteverde Butterfly Garden and Wenhua Lu for teaching me that insects make the world go round. To all of my excellent friends who have supported me throughout this entire process, in particular, my friends in Columbia who still call me even though I'm too busy to hang out. To Dan F. for Newsies sing-alongs during my first and hardest semester and to Corinna for being the best study buddy and roommate ever during my last, equally as hard semester. To Amanda, Delia, and Hannah Rainey for being my music family and making sure I shared my music with this community despite my being in graduate school (I think it did me better than anyone else!). To my neighbors for excellent food and company. To my brother Neal for always making me crack up and reminding me that I am other things besides a student. To Mims and Kelly for being supportive and making my awesome nephew, Felix. Taking breaks to look at photos and videos of y'all always made me smile. To Price and my mom, Vikki, for reminding me not to take life too seriously, for calling me excitedly to ask about garden bugs and trees and plants, and for creating such a wonderful space for resting and feeling peaceful when I visit, desperately needing to rest and feel peaceful. To Robbie Lou: I never thought I'd be such good friends with my grandmother! Thanks for always picking up your phone on cold and rainy days as I walk to school because your laugh makes every day easier! To my dad, Mims, for always understanding and appreciating the sacrifices one makes when they work hard, for frequent visits and advice, and a particular conversation around Easter 2011 that made a difference in the rest of my career as a grad student. To Winnie for reminding me to get outside and take care of myself and to be joyful and thankful and present. To Jesse for being my best friend, for always listening eagerly whether you were interested or not, for back rubs, dinners, hugs, dog walks, Broadway brewery beers, sweet messages, and baths when things were hardest. For loving me unconditionally through it all. I love all y'all and couldn't have done this without you. 


\section{ACKNOWLEDGEMENTS}

I would, first and foremost, like to thank my charismatic and inspiring advisor, RoseMarie Muzika, for her guidance throughout this entire process. Thank you for your hands-on direction while still allowing me autonomy. This is how I best learn and why I think we operate with such a nice rapport. To my committee member, Francisco Aguilar, thank you for helping me see that my weaknesses may actually be strengths that just need a little polishing. To my other committee member, Richard Houseman, thanks for never putting a time limit on our meetings so that hashing out details and brainstorming never felt rushed. To the USDA National Needs Fellowship Program for funding this research. I am forever grateful to my awesome lab mates, Chad King, Christine Steinwand, Pattie Quackenbush, Christopher Lee, and Nathan Weber, for always being willing to get interrupted a lot to listen to my ideas, complaints, and questions without judgment or criticism. Chad, I would have NEVER survived my first semester without your support. Thank you so much for listening and convincing me that, whatever was going on, was not the end of the world. Christine, thank you for stats help but mostly for being an excellent collaborator, travel buddy, field partner and friend. You have a golden heart. Pattie, you have always been willing to help and share your experience without hesitation, in fact, I feel quite certain that I would have had a nervous breakdown in Stats 7510 without your help. Chris, you are pretty much the kindest soul I know. Thank you for your patience and perpetual tranquility and sweetness. Nathan, thanks for always shaking things up a little and making lab conversations more interesting. To all who helped me collect data including, Ryan Sims, Megan Mustoe, Phillip Mohebalian, Zhen Cai, Bo Yuan, Aaron Stevenson, Randy Evans, Matt Bourscheidt, Gabe Waterhouse, Calvin Maginel and Carter Kinkead, thank you so much for digging holes in rocky soils, on steep slopes, in heat indexes $>105^{\circ} \mathrm{F}$. In particular, I would like to thank Gabe Waterhouse 
and Calvin Maginel for being great friends, band mates (The Erigeron Gangstas!), botany crewmates, and making field work that took me a week to do alone happen in a day. To a suite of incredible lab assistants, Sierra Schilling, Kara Jamison, Brianna Lynch, Katie Woods, and Kristen Bird, thank you for using your hard-earned entomology skills to assist me in sorting my pitfall traps. I, especially, want to thank Ashley Schulz for putting in countless hours sorting traps and identifying ants. You have an amazing work ethic, my friend, I appreciate you more than I can say. Carter Kinkead, was a constant help through out the past three years, selflessly spending time explaining our study site, giving stats advice and above all being an excellent friend and colleague. John Kabrick and the USDA Forest Service Northern Research Station kindly offered to let me use their study sites and John was always willing to meet and give advice. Thanks to Texas Nall of the Forest Service for help at Sinkin and JFS. Thanks Katie O'Donnell for showing me around the Sinkin. Laura Conners, you've always been willing to help me when I've been in a bind, need a meeting, need to buy something last minute, but mostly when I just need to vent. I would have been lost when it came to ant identification without the help and expertise of James Trager. Thank you for voucher confirmation sessions and putting so much time and thought into my antrelated emails and questions. If I ever discover a new ant, it will be named after you! Thanks to Jan Weaver and Ken Puliafico for helping me realize I should focus my study on ants, creatures I have come to find fascinating. To Mark Pelton for his help with fire history information at University Forest Conservation Area. To Mark Ellersieck for teaching me about statistics and coaching me through my analysis. Thanks for selflessly spending time on a stressed out grad student! And finally to the guys in the SAS help lab! Thanks for helping me understand the basics so I could navigate that crazy program on my own. 


\section{TABLE OF CONTENTS}

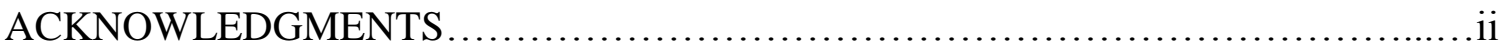

TABLE OF CONTENTS ..........................................................

LIST OF TABLES..............................................................

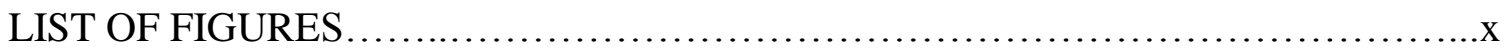

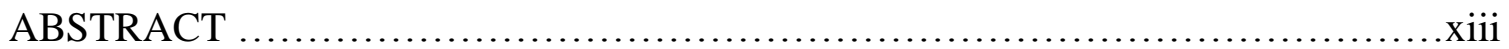

CHAPTER 1. INTRODUCTION AND LITERATURE REVIEW .......................1

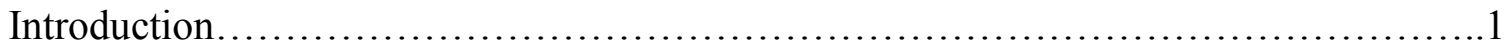

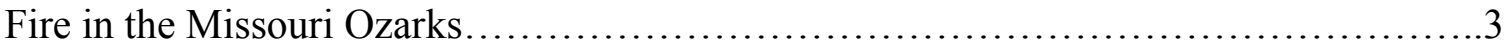

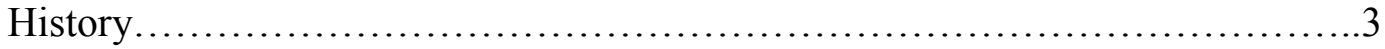

Current use of fire in Missouri...................................................

Fire behavior.............................................................

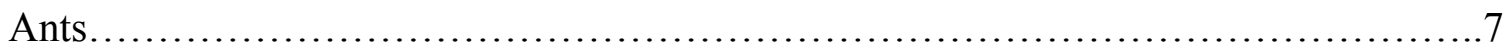

Life history and ecology .................................................

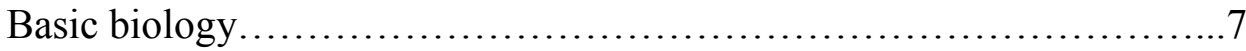

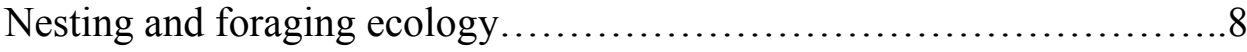

Myrmecochory and myrmecophory ..................................10

Ant community ecology: thermoregulation...........................11

Ant community ecology: competition and dominance...................12

Functional groups........................................................ 14

Ants as bioindicators of biodiversity and ecosystem health....................16

Responses of ants to prescribed burning .................................. 18

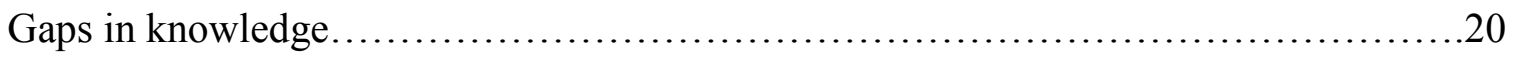

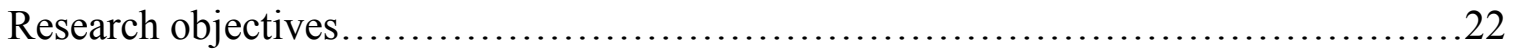

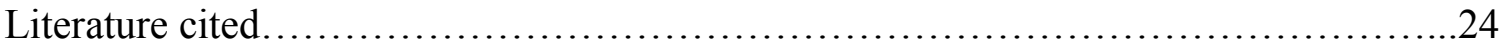




\section{CHAPTER 2. EFFECTS OF OVER 60 YEARS OF PRESCRIBED BURNING ON ANT}

FORAGING ACTIVITY AND ECOLOGICAL FUNCTION $\ldots \ldots \ldots \ldots \ldots \ldots \ldots \ldots \ldots . \ldots . \ldots . \ldots . \ldots$

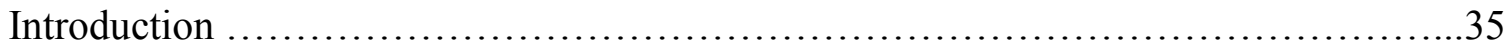

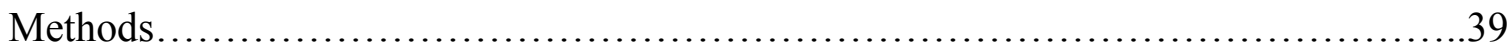

Study site....................................................... 39

Experimental design...............................................41

Ant sampling........................................................41

Sample Processing.. ..............................................45

Functional Groups.....................................................45

Nesting behavior and size classes...................................46

Statistical analysis...................................................48

Diversity and abundance.....................................48

Functional groups, size classes, nesting groups and species............50

Buffers.................................................. 52

Results....................................................................... 52

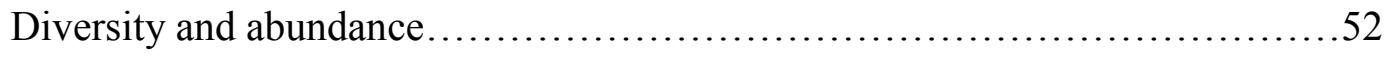

Functional groups..................................................55

Nesting behavior.................................................. 55

Size class........................................................56

Species........................................................57

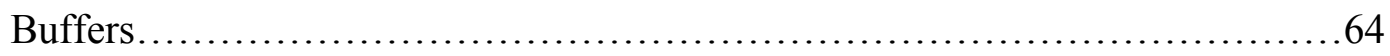

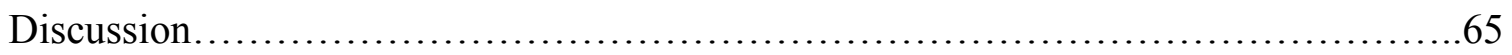

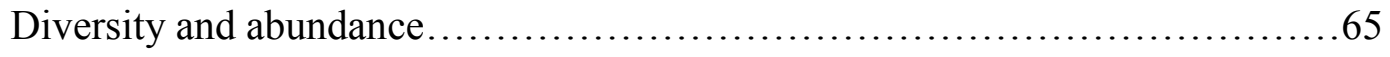

Functional groups................................................. 68

Nesting groups..................................................69

Size class........................................................... 70 


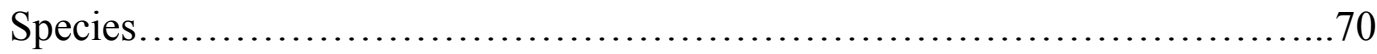

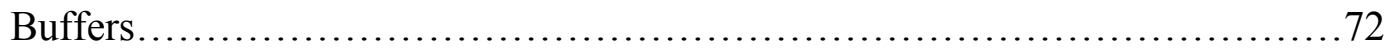

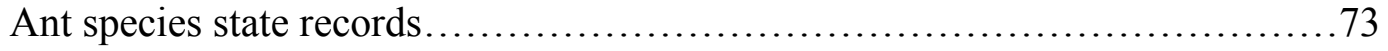

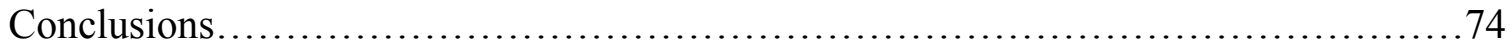

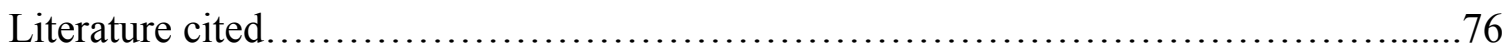

CHAPTER 3. RESPONSES OF GROUND-FORAGING ANT ASSEMBLAGES TO PRESCRIBED FIRE AND TOPOGRAPHIC POSITION IN AN OAK WOODLAND

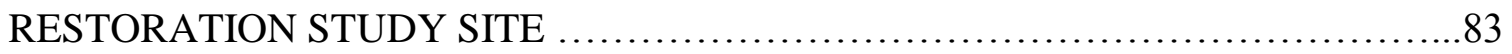

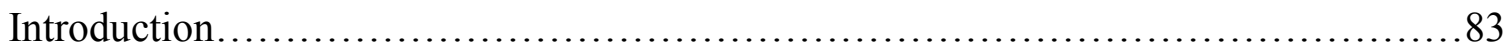

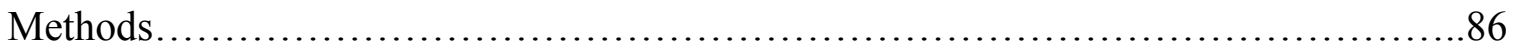

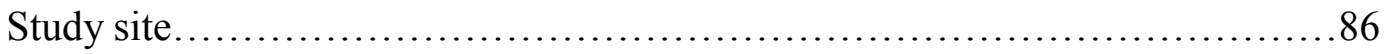

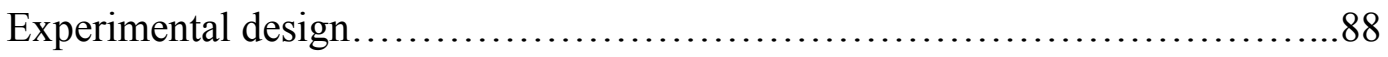

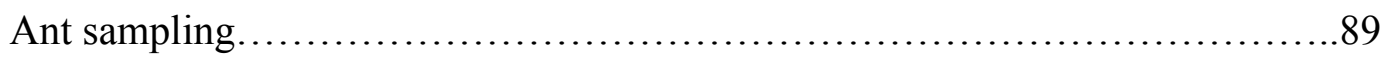

Functional groups, nesting groups, and size classes.........................90

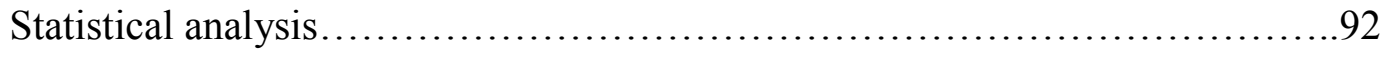

Abundance and diversity ........................................ 92

Functional groups, size classes, nesting groups and species.............93

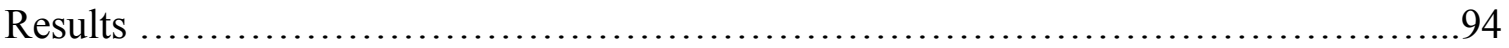

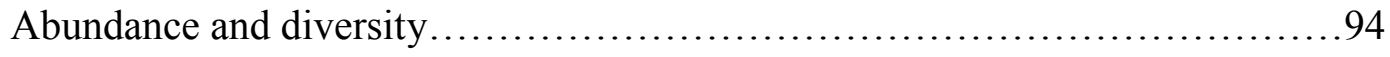

Functional groups, nesting groups, and size classes.........................96

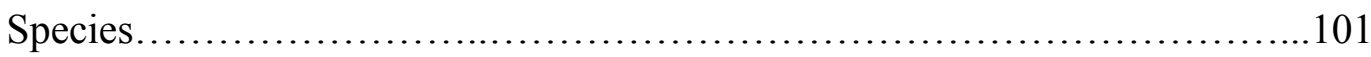

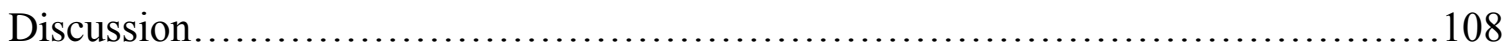

Management implications............................................... 110

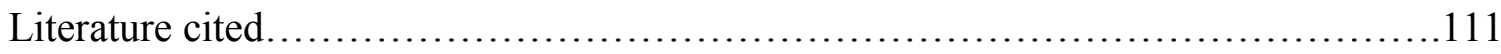


CHAPTER 4: THE POTENTIAL USE OF ANTS IN MONITORING ECOLOGICAL CHANGE AFTER PRESCRIBED BURNING IN THE MISSOURI OZARKS:

SYNTHESIS AND FUTURE DIRECTIONS ...................................118

Comparison of two case studies...........................................118

University Forest Conservation Area (UFCA) ............................118

Logan Creek and Clearwater Creek Conservation Areas: Joint Fires Science

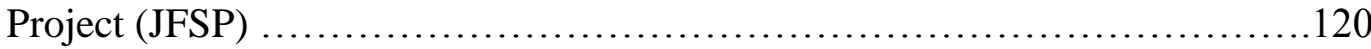

Utility of ants in forest management in Missouri Ozarks............................124

Future research directions.................................................. 125

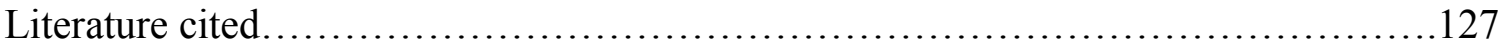




\section{LIST OF TABLES}

Table 1.1. Description of functional groups (Andersen 1995) and categorization of Missouri ant genera. Based on Andersen 1997 and Izhaki et al. 2003.

Table 2.1. Burn records at the University Forest Conservation area from 1997 to 2013 including climatic characteristics and burn notes (Courtesy of Mark Pelton, Missouri Department of Conservation).

Table 2.2. Functional groups used in this study and their descriptions based on Andersen (1995).

Table 2.3. Subfamilies and species found at University Forest Conservation Area and their corresponding functional group, nesting group, and size class designations.

Table 2.4. List of indices used to assess diversity of ant assemblages at the University Forest Conservation Area.

Table 2.5. Diversity measures of ant assemblages by year and treatment.

Table 2.6. Results from the multiple response permutation procedure performed between treatments. The test statistic (T) is used to calculate between group or treatment separation (the more negative a value signifies a greater degree of separation). The agreement statistic (A) evaluates within group homogeneity (when $A=1$ communities are perfectly similar). P-values are generated using the Pearson type III distribution based on the test statistic.

Table. 2.7. Observed species richness and Chao2 incidence-based richness estimates are represented for each buffer category. Comparisons using incidence-based Sorenson Similarity Indices and number of shared species are also displayed.

Table 3.1. Pretreatment and post-fire tree density, basal area and Gingrich (1976) stocking level at the study site. Adapted from Kinkead (2013).

Table 3.2. Subfamilies and species found at JFSP site, Logan Creek and Clearwater Creek Conservation Areas and their corresponding functional group, nesting group, and size class designations.

Table 3.3. Diversity measures of ant assemblages by treatment and topographic position.

Table 3.4. Percent canopy openness recorded in tandem with this study in July 2011 at Logan Creek and Clearwater Creek Conservation Areas (Kinkead 2013).

Table 3.5. Results from the multiple response permutation procedure performed between treatments and topographic position. The test statistic $(\mathrm{T})$ is used to calculate between group or treatment separation (the more negative a value signifies a greater degree of separation). The agreement statistic (A) evaluates within group homogeneity (when $A=1$ 
communities are perfectly similar). P-values are generated using the Pearson type III distribution based on the test statistic. 


\section{LIST OF FIGURES}

Fig. 1.1. Castes of ant species, Pheidole dentata, including A) the queen or gyne, B) the male or alate, C) a major worker, and D) a minor worker (http://www.antweb.org)

Fig. 1.2. A) Individuals Aphaenogaster fulva feed on the elaiosome of the spring ephemeral, Sanguineria canadensis (bloodroot). B) This cricket in the genus Myrmocophilus lives in ant colonies and mimics ant behavior to solicit food. Here it is shown with Crematogaster lineolata. Photos by Alex Wild.

Fig. 2.1. A)Maps of the University Forest Conservation Area located in the Black River Ozark Border subsection in the southeastern corner of the Missouri Ozark Highlands. B) The Wappapello Oak-Pine Woodland/Forest Hills are the associated land types in the region (Nigh and Schroeder 2002).

Fig. 2.2. Randomized block design at the University Forest Conservations Area. F1(left), was a well stocked oak-hickory forest pretreatment and shows location of pitfall traps in grey. F2 (right) is an upland flatwoods with oak-hickory pretreatment forest composition. $\mathrm{C}=\mathrm{Control}, \mathrm{A}=$ Annual, $\mathrm{P}=$ Periodic. Numbers indicate plot number.

Fig. 2.3. Total abundance per trap of all ants across all treatments and blocks (mean +1 standard error) in A) 2011 and B) 2012.

Fig. 2.4. Relative frequencies of functional groups in all three treatments for A) 2011 and B) 2012 .

Fig. 2.5. Relative frequencies of nesting groups in all three treatments for A) 2011 B) and 2012.

Fig. 2.6. Abundance per trap for small, medium and large size classes in all three treatments for A) 2011 and B) 2012. Error bars indicate mean +1 standard error.

Fig. 2.7. Species mean abundances per trap for A) control plots including Aphaenogaster carolinensis $/ \mathrm{n}=19$, Camponotus chromaiodes, and Temnothorax pergandei, B) annually burned plots including Monomorium minimum, Pheidole dentata, Pheidole tysoni, and Trachymyrmex septentrionalis, and C) periodically burned plots including Strumygenys talpa and Tapinoma sessile. Error bars indicate mean +1 standard error. -Letters indicate significant differences between treatments.

*indicates significant differences between years.

Fig. 2.8. Species mean abundances per trap for A) control/periodic plots including Aphaenogaster lamellidens, Crematogaster lineolata, Formica pallidefulva, Myrmica pinetorum and Myrmica punctiventris, B) annually and periodically burned plots including Aphaenogaster treatae, Nylanderia trageri, and Solenopsis spp., C) all treatments including Camponotus pennsylvanicus, Crematogaster ashmeadi, and 
Formica dolosa and D) control and annually burned plots including Camponotus americana. Error bars indicate the mean +1 standard error.

-Letters indicate significant differences between treatments.

*indicates significant differences between years.

Fig. 2.9. A) Abundance-based Morisita similarity indices between all treatments combined. Pairwise incidence-based Morisita similarity indices between B) control and annual, C) control and periodical, and D) annual and periodic burns. The more the circles overlap the more similar the assemblages.

Fig. 2.10. Pairwise abundance-based Morisita similarity indices between 2011 and 2012 ant assemblages. The more the circles overlap the more similar the assemblages.

Fig. 2.11. Nonmetric multidimensional scaling ordination of treatments.

Fig. 2.12. Nonmetric multidimensional scaling ordination of buffer communities.

Fig. 2.13. Images of treatments at UFCA including A) control, B) annual, and C) periodic.

Fig. 3.1. Location of the Joint Fire Science Project (JFSP) study area in the Missouri Ozarks. The two blocks, Logan Creek and Clearwater Creek Conservation Areas. are located in the Black River Oak-Pine Woodland/Forest Hills Land Type Association.

Fig. 3.2. Overstory plot vegetation plot. Pitfall traps were placed one meter north of each $1 \times 1$ meter (numbered 1-6) randomly placed on a $36 \mathrm{~m}^{2}$ grid.

Fig. 3.3. Mean total abundance per trap for each aspect/slope position within treatment. Error bars show mean +1 standard error.

Fig. 3.4. Simple linear regression showing association between percent canopy openness and observed species richness.

Fig. 3.5. Relative frequencies of functional groups across treatment.

Fig. 3.6. Relative frequencies of functional groups across aspect/slope position.

Fig. 3.7. Simple linear regression showing association between percent canopy openness and mean abundance per trap of A) Cold Climate Specialists and B) Generalized Myrmicinae.

Fig. 3.8. Relative frequencies of nesting groups across treatments.

Fig. 3.9. Relative frequencies of nesting groups across aspect/slope position.

Fig. 3.10. Simple linear regression showing association between percent canopy openness and mean abundance per trap of A) arboreal nesters and B) soil nesters. 
Fig. 3.11. Abundance per trap for small, medium and large size classes by treatment. Error bars show mean +1 standard error.

Fig. 3.12. Abundance per trap for small, medium and large size classes by slope/aspect position. Error bars show mean +1 standard error.

Fig. 3.13. Simple linear regression showing association between percent canopy openness and mean abundance per trap of small ants.

Fig. 3.14. Ants that were found commonly across all treatments and topographic positions including A) Camponotus americanus, B) Aphaenogaster group, C) Camponotus chromaiodes, D) Crematogaster lineolata, and E) Formica pallidefulva. Error bars indicate the mean +1 standard error.

Fig. 3.15. Species of ants that responded to treatment, topographic position or their interaction including A) Formica dolosa, B) Formica subsiricea, C) Myrmecina americana, D) Myrmica pinetorum, E) Nylanderia faisonensis, F) Solenopsis spp., G) Temnothorax curvispinosus, and H) T. pergandei. Error bars indicate the mean +1 standard error.

Fig. 3.16 . Simple linear regression showing correlation between percent canopy openness and mean abundance per trap of A) Aphaenogaster carolinensis/n19, B) Crematogaster lineolata, C) Formica dolosa, D) Myrmica pinetorum, and E) Temnothorax pergandei.

Fig. 3.17. Morisita similarity indices between all topographic positions combined (top), and pairwise comparisons between treatments and topographic positions.

Fig. 3.18. Nonmetric multidimensional scaling ordination of treatments.

Fig. 3.19. Nonmetric multidimensional scaling ordination of topographic position.

Fig. 4.1. Morisita Similarity Index between all assemblages across all treatments at sites 1 (UFCA) and 2 (JFSP) combined, ROW 1: Site 1 treatments and site 2 treatments, ROW 2: control areas at site 2 (LCCA/CCCA) compared with control (left), annually burned plots (middle) and periodically burned plots (right) at site 1 (UFCA), ROW 3: burned areas at site 2 (LCCA/CCCA) compared with control (left), annually burned plots (middle) and periodically burned plots (right) at site 1 (UFCA). 


\begin{abstract}
Fire is an important tool in the sustainable management of ecosystems at global and local scales. In addition to increasing biodiversity, fire has been shown to decrease exotic species invasion, promote growth of commercially and ecologically important trees, and reduce risk of wildfire. Missouri has a long history of anthropogenic and naturally induced fire aiding the establishment of oak and pine-dominated woodlands and savannas. Fire has been reintroduced through forest management in the region after a period of fire suppression to help retain oak-dominance in forests throughout Missouri. Research on the effects of fire is ample for many wildlife species and plants but virtually excludes insects including ants, especially in Missouri and most of the United States. Ants are considered ecosystem engineers for their contribution to soil turnover, aeration and chemical and structural modification and are important seed dispersers. The effects of prescribed burning on ant assemblage diversity, abundance, composition and function were examined in oak-hickory and oak-pine forests in the Missouri Ozark Highlands. Where fire was present annually for over sixty years, ant abundance, Generalized Myrmicinae, soil and litter nesters and small ants increased. Fire every four years for over sixty years resulted in higher Shannon diversity, Cryptic Species, litter nesters and small and medium ants. In addition, this treatment shared ants with both the control and annually burned plots. Control plots were dominated by Subordinate Camponotini, Cold Climate Specialists, wood nesters and medium sized ants. Ants were also assessed after just two fires over the course of ten years. Five and six years after fire ant assemblages were more affected by topographic position than by prescribed burning. Ant assemblages of burned and unburned sites were homogenous when compared using a Morisita Similiarity index. When comparing these treatments to those that have been burned for over sixty years using the Similarity index, both were more similar to the control. In summary, long term fire implementation results in more lasting changes in ant
\end{abstract}


communities because habitat alteration is maintained over time. Habitat heterogeneity

produces a more diverse assemblage of ants at the landscape scale and hence higher

functional diversity. Finally, categorization of ant communities may simplify ant sampling so that the natural history of each species need not be known in order to assess ecological effects of ant assemblages associated with burn treatments. 


\section{CHAPTER 1. INTRODUCTION AND LITERATURE REVIEW}

\section{Introduction}

Many nations across the world have been adopting sustainable forest management (SFM) strategies to preserve natural ecosystems and their diversity. SFM can be used to address a changing climate, the adverse effects of an ever-increasing human population, and demands on natural resources. Voluntary programs like the Montreal Process, The Dry Zone Africa Process, The Lepaterique Process, The Near East Process, etc., have developed criteria and indicators to address such issues as conservation of biological diversity, maintaining forest health and productivity, and water and soil conservation (FAO 2001). SFM aims to meet the needs of the present generation of humans in their use of forest resources while protecting the integrity of these ecosystems for future generations (FAO 2011); an important objective of SFM is biodiversity maintenance and conservation in order to maintain ecosystem stability and function (Lindenmayer et al. 2000). One way to promote biodiversity through SFM is fire management to prevent life and habitat threatening fires and encourage prescribed burns that restore and favor biodiversity in fire-adapted ecosystems as recommended by the Convention on Biological Diversity (FAO 2009). Fire management is increasingly utilized in many states in the US to reduce fuel loads to prevent catastrophic wildfires and restore natural communities. Missouri is one such state with a rich fire history, once representing the spectrum of terrestrial natural communities along the prairie/forest continuum.

Fire is currently used commonly in the Missouri Ozarks to meet various management objectives: to decrease invasive plants species, to promote the growth and regeneration of commercially important tree species, to favor wildlife habitat and to restore terrestrial natural communities. Reconstructed disturbance histories of forests 
using dendrochronology, palynology, paleoecology and other tools suggest that fire was widespread throughout the Missouri Ozark Highlands and is correlated to human population dynamics (Delcourt et al. 1986, Guyette and Cutter 1991, Cutter and Guyette 1994, Guyette and Cutter 1997, Guyette and Dey 2000, Guyette et al. 2002, Guyette and Spetich 2003). Most research on prescribed burning in the region has assessed how fire affects the biodiversity of plant communities, birds, herpetofauna and mammals (Guyette and Kabrick 2002, Keyser and Ford 2006, Bell 2007) yet no studies exist that explore responses of arthropods.

Arthropods are the most diverse group of animals on Earth making up more than half of the described species of all organisms (Price 2002) and are estimated to contain 510 million species, in addition to those still unknown to science (Gaston 1991, Gaston 1992, Odegaard 2000). The bulk of the literature that assesses prescribed fire's effects on arthropods in forests and savannas focuses on soil and litter fauna because they are characteristically less mobile and hence are less likely to escape a burn.

The most abundant litter and soil dwelling insect is the ant (Hymenoptera: Formicidae). Ants make up a significant amount of Earth's total biomass with 10,000 trillion individuals on the planet (Hölldobler and Wilson 1990) and therefore must occupy myriad ecological niches (Lach et al. 2010). There are currently more than 12,500 described species of ants worldwide but it is estimated that 25,000-30,000 exist (May 1988, Bolton et al. 2006, Lach et al. 2010). Ants are known to be ecological engineers due to their diverse interactions with their environment and other organisms (Lawton 1994, Folgarait 1998, Kaspari 2000, Unstad 2012); most notably, they modify physical and chemical characteristics of the soil, act as predators of other invertebrates and 
disperse seeds of many plant taxa. Their contribution to ecological processes, abundance, diversity and facility of sampling and identification make them useful bioindicators in land management (Andersen 1997b, King et al. 1998, de Bruyn 1999, Read and Andersen 2000, Andersen et al. 2002, Andersen and Majer 2004, Underwood and Fisher 2006). In Australia managers have incorporated ants into monitoring programs with particular emphasis on their diversity and differences in community assemblage after prescribed fire. However, there are still relatively few case studies of the effects of prescribed burning on ant assemblages in the United States and none in Missouri.

This review seeks to (1) explore the historical and current use of prescribed fire in the Ozark Highlands and its effects on Missouri flora and fauna, (2) to examine the ecological roles of ants, (3) to evaluate their use as biological indicators, and (4) understand the effects of prescribed fire on their community assemblages. Finally, (5) I identify gaps in this literature and (6) present the research objectives of this project.

\section{Fire in the Missouri Ozarks}

\section{History}

Oak forests, affiliated regularly with frequent fire, have dominated the Eastern United States for thousands of years (Abrams 1992). In Missouri, open woodlands and savannas of widely spaced oaks, hickories and pines towering over a "shrub-free", diverse matrix of warm-season grasses and wildflowers are described in many historical accounts of the landscape (Ladd 1991), and reveal characteristics that were likely maintained by frequent fire. Reconstructed fire histories using fire scars indicate that burning was commonplace over the last few hundred years (Cutter and Guyette 1994, 
Guyette et al. 2002, Guyette et al. 2006). Accounts of early Euro-American settlers describe the use of fire by Native Americans to keep the understory clear of vegetation to increase visibility for hunting and enemies (Ladd 1991); one such account outlines the use of fire to urge prey in the direction of hunters (Sauer 1920). In historic fire regimes in the Ozarks the vast majority of fires were anthropogenic (Guyette and Dey 2000). Fire intervals and frequencies have been documented throughout much of the Ozarks (Guyette and Cutter 1991, Cutter and Guyette 1994, Jenkins et al. 1997, Guyette and Spetich 2003, Stambaugh and Guyette 2006) and are spatially and temporally variable likely due to the interaction between human population dynamics throughout history and fire frequency (Guyette et al. 2002).

Before Euro-American settlement, fires were common but reflected low populations of Native Americans with mean fire-free intervals of 10 years (Guyette et al. 2002). Fire frequency increased as Euro-Americans settled the land in the mid-1800s, bringing with them a culture of burning and fire-free intervals decreased to 3.5 years (Guyette and Dey 2000, Guyette et al. 2002, Stambaugh and Guyette 2006). This increase in fire frequency put pressure on the fuel resource resulting in a decline in anthropogenic fire and ultimately fire suppression by the early and mid-1900s. Clear cutting of timber was common early in the twentieth century followed by high intensity fires in part because of the accumulation of fuel (Hartman 2005); these fires, often promoted soil erosion and the diminishment of seed bank quality of grasses and forbs. Many settlers in the Ozark region were of Scotch-Irish decent (Guyette and Dey 2000) and had practiced burning; it remained a part of tradition in the Ozarks throughout the early years of fire suppression policies in the first half of the $20^{\text {th }}$ century as a means of showing 
dissatisfaction of government acquisition of property in the Ozarks (Strausberg and Hough 1997, Stephens and Ruth 2005). Policies were supported federally, inspired by catastrophic wildfires (Fralish 2004). The consequences of these policies contradicted their intended effect; fuel loads increased, closed-canopy forests developed, and oak regeneration declined. Encroachment of mesophytic, shade-tolerant tree species and invasive species in the mid and understories of stands also occurred as a result of fire suppression (Pallardy et al. 1988, Nowacki and Abrams 2008). The process of mesophication can affect wildlife; shadier forests suppress diverse understory flora and oak regeneration that serve as forage for deer and decline of oaks mean less hard mast that are key to the diets of many wildlife species like turkeys, quail, and other small mammals (Hartman 2005). These consequences and early research in fire ecology eventually illuminated the importance of fire in maintaining oak forests, woodlands, and savannas.

\section{Current use of fire in the Missouri Ozarks}

In Missouri, management with fire was re-initiated in the 1970s (Hartman 2005) and is on the rise (Arthur et al. 2012). Fire is used to restore oak-dominated woodlands and savannas to their pre-European state (McCarty 1998), but also to reduce fuel loads (Lowenstein et al. 2002), invasive plant species and promote wildlife habitat. State, federal and private land management agencies (e.g. Missouri Department of Conservation, US Forest Service, Nature Conservancy) increasingly require the use of fire as a management tool throughout Missouri (The Nature Conservancy, USDA Forest Service Daniel Boone National Forest 2005, USDA Forest Service Mark Twain National 
Forest 2005); in 2012, approximately 99,000 acres of public land were burned in the state compared with approximately 69,000 in 1999 (Lowenstein et al. 2002, Godwin 2013). At times prescribed burning is employed before scientific research has enlightened potential ecological consequences of using fire as a management tool (Arthur et al. 2012). Programs like The Oak Woodlands and Forests Fire Consortium (http://www.oakfirescience.com/) are synthesizing and summarizing scientific fire research for land managers who are practicing fire management but much research still needs to be done.

\section{Fire behavior}

Fire frequency and intensity will affect the ecosystem response to it. Time between fires allows for the biotic community to recover from the disturbance. Fire intensity is related to seasonality of a fire, fuel moisture (often dependent on climate, slope and aspect), and fuel loading (Pyne 1984, Alexander et al. 2006). The higher the temperature, lower the relative humidity, and more fuels, the hotter a fire will burn. Higher intensity fires will remove more biomass requiring a longer recovery time; lower intensity fires may have higher moisture, less fuel loading and may occur in cooler temperatures (Whelan 1995). Topography, meteorology and fuels differ throughout a landscape resulting in variation in fire intensity. For instance, in the northern hemisphere slopes that face south receive more sun and therefore dry out, burning with greater severity (Weatherspoon and Skinner 1995, Alexander et al. 2006). This variation results in a mosaic natural community types along the prairie to forest spectrum often including unburned patches, serving as refugia for plants and wildlife (Roman-Cuesta et al. 2009). 
Fire is known to increase floral diversity and benefit fauna that prefer open habitats (e.g. woodland plants and grasses, birds, collared lizard) (Guyette and Kabrick 2002, Brisson et al. 2003, Dey and Hartman 2005, Keyser and Ford 2006, Bell 2007, Phillips et al. 2007, Kinkead 2013) yet fire management practices regarding size of burn areas, fire frequency, and seasonality that best favor plants and wildlife are still being developed. To fully understand what is happening when a forest is burned, the effects on insects should be considered as they are abundant and have notable contributions to forest ecology (Scholwater 2011). Ants are functionally and taxonomically diverse and are particularly easy to sample at a landscape scale because they are abundant (Underwood and Fisher 2006).

\section{Ants}

\section{Life history and ecology}

Basic biology

Ants are eusocial insects that are divided into several castes: worker, reproductive males, and reproductive females, queens, or gynes (Fig. 1.1) (Hölldobler and Wilson 1990). Colonies are made up of as few as 10 (Wilson 1959) and as many as 307 million individuals (Higashi and Yamauchi 1979) depending on species and colony establishment strategy. Reproductive queens are long-lived, surviving from many weeks to many years; some queens in the genera Camponotus, Formica, and Lasius have lifespans of up to 29 years (Hölldobler and Wilson 1990). The lifespan of a queen reflects the longevity of a colony except when colonies become so large that they coalesce and may exist for longer under the reign of multiple queens. After their mating flight, queens support themselves 
on stored energy until they produce enough workers to feed her and take over brood management; when new reproductive queens and males leave their colonies for their own nuptial flight the life cycle is complete (Hölldobler and Wilson 1990, Kaspari 2000). Hölldobler and Wilson (1990) compare stationary ant colonies to plants that send out seeds (reproductives) perennially; nests are trackable across time and may respond to stress or disturbance (Andersen 1995).

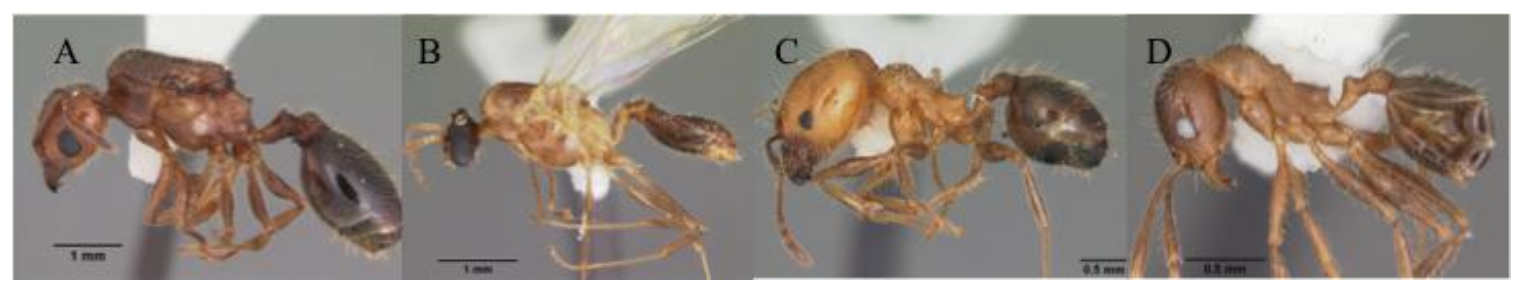

Fig. 1.1. Castes of ant species, Pheidole dentata, including A) the queen or gyne, B) the male or alate, C) a major worker, and D) a minor worker (http://www.antweb.org)

Nesting and foraging ecology

The availability of ant nesting sites increases with the structural complexity of a habitat (Andersen 1991, MacKay et al. 1991, Farji-Brener et al. 2002). In deserts, grasslands, and shrublands ants will nest primarily in the ground and occasionally in hollow cavities of plants, twigs or seeds. Many ants also nest and forage in the canopy, branches and trunks of trees. Therefore, savannas, woodlands and forests provide more nesting niches for ants. Coarse woody debris, snags, or partially rotting trees can house several colonies at a time; leaf litter provides further nesting habitat and foraging area for ants including cryptic species that spend most of their time below the soil surface.

Foraging strategies also vary amongst ant species. Many ants are either generalist or opportunistic feeders. Both groups are able to feed on a range of foods from dead and 
decaying organic matter, to Homopteran honeydew, live and dead insects, elaiosomes of seeds and nectaries of plants. Generalists recruit other ants to a location to defend the site and break down food more efficiently while opportunists tend to send out individuals to forage (Andersen 1995, 1997, Izhaki et al. 2001). Some ants are more specialized. Slavemaking ants including Polyergus spp., Protomognathus spp., and some Formica spp., subjugate ants of other colonies to do their foraging and can be completely dependent on those colonies for survival (Coovert 2005, Fisher and Cover 2007). Some ants specialize on other organisms; the cryptic Strumigenys spp., for example, eat only springtails in the soil and leaf litter (Fisher and Cover 2007). Social parasitism is common in some genera of ants; species of Solenopsis steal food resources and brood from other ant colonies (MacKay and MacKay 2002). Many ant specialists, generalists, and underground cryptic species tend or farm aphids and other homopterans; in exchange for the sugar-laden honeydew produced by these insects, ants keep the plant clean of the sticky substance and will protect the aphids and their host plant from predators (Hölldobler and Wilson 1990).

Nesting and foraging behavior in ants have ecological impacts that contribute to ecosystem processes and community dynamics; due to the vast number of individuals in an ecosystem and the degree of their contribution they are considered ecosystem engineers (Folgarait 1998). Excavation of soil nests aerates soil, increasing moistureholding capacity. They also break down organic matter enriching the soil and changing its chemistry (Folgarait 1998). Ants create 'middens' for unwanted food items, excrement, and fallen nestmates; these middens increase nutrient deposition enhancing the soil's quality for plant establishment (Hölldobler and Wilson 1990). Beattie and 
Culver (1977) found seven species of plants associated with mounds of Formica obscuripes in a midwestern prairie.

Myrmecochory and myrmecophory

Myrmecochory occurs when plant seeds are dispersed by ants (Hölldobler and Wilson 1990); the elaiosome of these seeds contains proteins and lipids that attract ants (Fig. 1.2A) (Marshall et al. 1979, Rico-Gray and Oliveira 2007). These seeds are often carried back to the nest and, after the elaiosome is eaten, disposed of in the dark, moist, and nutrient rich soil of the nest where it will often grow (Culver and Beattie 1978, Thompson 1981, Rico-Gray and Oliveira 2007). In this way many plants are dependent on ants for dispersal of their seeds. In fact, $40 \%$ of herbaceous plant species in eastern deciduous forests of North America (Beattie and Culver 1981, Ness et al. 2009), including many spring ephemerals, are myrmecochores (Culver and Beattie 1978, Pudlo et al. 1980, Hölldobler and Wilson 1990). In an experiment that excluded ants from seeds of wild ginger Asarum canadense, the majority of seeds were depredated by mice; where ants were present only a third were destroyed (Heithaus 1981).

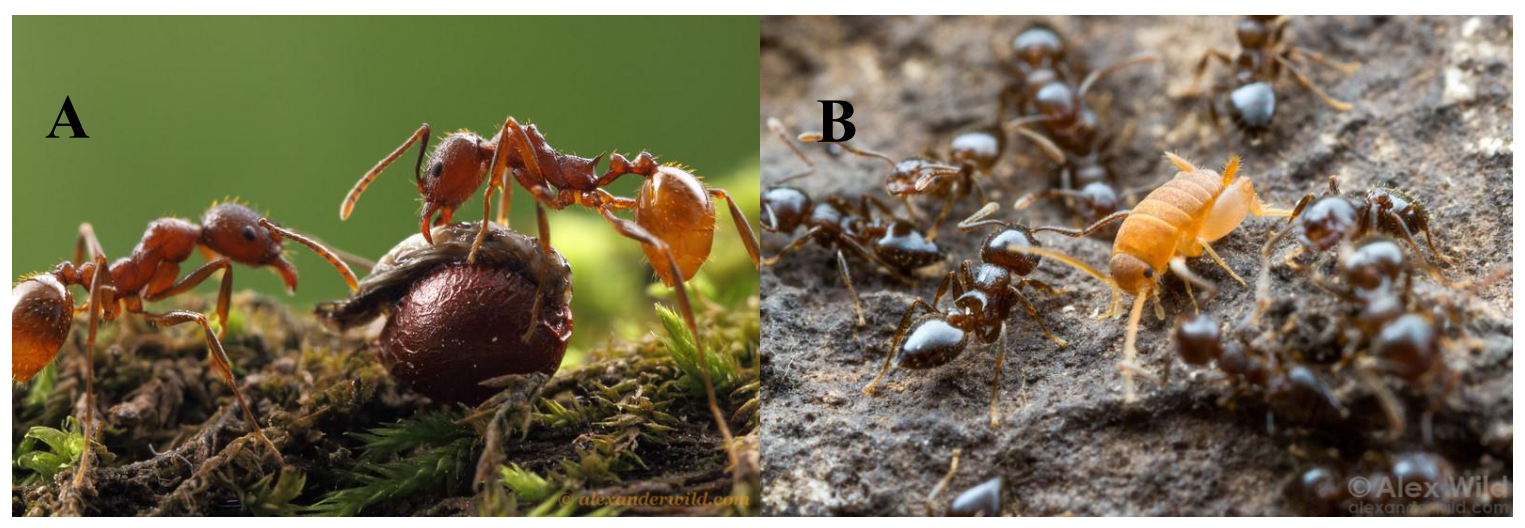

Fig. 1.2. A) Individuals Aphaenogaster fulva feed on the elaiosome of the spring ephemeral, Sanguineria canadensis (bloodroot). B) This cricket in the genus 
Myrmocophilus lives in ant colonies and mimics ant behavior to solicit food. Here it is shown with Crematogaster lineolata. Photos by Alex Wild.

Plants are not the only organisms that are dependent on ants. As mentioned before, ants tend honeydew-producing insects. Ants protect their resource, the aphids, by predating on other herbivores or predatory arthropods as the ants patrol the plant to shepherd their flock; studies have shown that this action results in higher plant fitness by reducing herbivory and gall-inducing insects (Strysky and Eubanks 2007). Parasitic, mutualistic and commensal myrmecophiles, organisms that live among ants, increase the biological and functional diversity of a site. In Ohio, prairie ants have been sampled for myrmechophilic mites resulting in 151 species residing in 273 ant colonies (Campbell et al. 2013). The chemical excretions produced by ants in a colony typically make it difficult for nest invaders to go undetected. Myrmecophiles have adapted by creating their own similar chemicals, rubbing on ants to obtain their scent or by mimicking ant behaviors. The cricket genus Myrmecophilus is commonly found in ant nests in Missouri (Wright 2013, unpublished data) and other parts of the US; it mimics movements of ants in order to solicit food (Fig. 1.2B) (Kronauer and Pierce 2011).

Ant community ecology: thermoregulation

A variety of interconnected factors determine population and community dynamics in ants, although climate, competition and resources seem to be the most influential (Kaspari 2000). Climatic characteristics like temperature and moisture can drive ant species distributions and foraging or nesting behaviors. Ants are prone to desiccation and therefore must be active in moderate temperatures. However, thermal tolerances among species and even colonies may vary (Verble 2012). For instance, 
Prenolepis imparis, is found throughout most of the United States but is most active early and late in the growing season when temperatures are cool (Wheeler 1930, Coovert 2005, Fisher and Cover 2007); on the other hand some species, like Cataglyphis bombycina, search for food in temperatures of greater than 60 degrees Celsius to avoid predation (Wehner et al. 1992, Verble 2012). Smaller bodied ants typically have lower heat tolerances than larger bodied ants, however, smaller ants with different nesting requirements may show increased tolerance to temperature (see Verble 2012). Variation in thermal tolerance may also lead to increased coexistence between species with varying degrees of behavioral dominance by allotting temporally distinct foraging times (Parr and Gibb 2010).

Ant community ecology: competition and dominance

Competition has been called "the hallmark of ant ecology" by Hölldobler and Wilson (1990). Competition can be both inter- and intraspecific. Both numerical and behavioral dominance may contribute to species richness and ecology of ants in a community. With increasing colony size and density, resources that may have been shared amongst fewer, less dense colonies are dominated by one large, dense colony (Kaspari 2000), an example of numerical dominance. Behavioral dominance is characterized by direct or indirect interactions Ants may directly encounter one another when expanding nests or foraging. Indirect interactions occur when one colony is more successful at discovering and/or defending food or nesting resources (Parr and Gibb 2010). Behavioral dominance is determined by assessing ant activity in and around bait traps; rates of food resource discovery and defense are monitored as well as surrender of 
that resource by a subordinate to a dominant ant (Andersen 1997a, Parr and Gibb 2010). Higher abundances of behaviorally or numerically dominant ant species can decrease species richness in more subordinate species (Parr and Gibb 2010).

Both climate and competition will influence the availability of resources. In addition, stress and disturbance can mediate availability of resources. Stressed environments (e.g. droughts, deserts, cold climates) may be more suitable for some ants than others thus reducing competitive interactions (Parr and Gibb 2010). In a stressed environment like the tundra, for instance, ants nest under stones that maintain warmer temperatures for longer (Brian and Brian 1951); this nesting strategy is unique, however, and species that may be better competitors in a less stressed environment do not thrive in the tundra. Disturbances remove biomass and alter habitat structure at different scales depending on the degree and frequency of the disturbance (Philpott et al. 2010) reducing resource availability and competitive interactions; disturbance may result in direct mortality of ants but many are only affected due to physical changes to their environment (Andersen 1995, Hoffman and Andersen 2003). Moreover, changes in structural complexity of the ecosystem may potentially affect functional diversity and species richness (Farji-Brener et al. 2002). Farji-Brener et al. (2002) found that ant diversity was similar in both burned and unburned Argentinian steppe, a less structurally complex, xeric ecosystem dominated by grasses and some shrubs, whereas in the shrub ecosystem, dominated by shrubs and mixed trees, ant diversity differed in burned and unburned plots. 


\section{Functional groups}

The preservation of biodiversity is an important component of sustainable forest management because diversity of species begets diversity of functions (Naeem and Li 1997, Samways et al. 2010). Functional diversity, or the range of ways in which the species in a community contribute to overall ecosystem function (Tilman 2001), can be a very telling measurement of diversity (Petchey and Gaston 2002) as it describes the frequency of interactions of a species with its environment. Sets of species that share a similar functional trait compose a functional group (Tilman 2001). Functional groups are widespread in their use as a measurement of functional diversity (Andersen 1995, Petchey and Gaston 2002, Andersen 2010, Samways et al. 2010) because they simplify an understanding of diverse communities (Andersen et al. 2002).

Andersen (1995) developed a functional group scheme for ants (Table 1.1) that has been implemented throughout Australia (King et al. 1998, Hoffman and Andersen 2003, Andersen and Majer 2004) and beyond (Izhaki et al. 2001, Farji-Brener et al. 2002, Ottonetti et al. 2006, Stephens and Wagner 2006, Mitrovich et al. 2010, Underwood and Quinn 2010, Unstad 2012, Ferganani et al. 2013, Moranz et al. 2013). The groups include Dominant Dolichoderine, Subordinate Camponotini, Cold and Hot Climate Specialists, Genereralized Myrmicinae, Opportunists, Cryptic Species, and Specialized Predators (Andersen 1995). This scheme is based on plant community functional groups and their responsiveness to competition, stress and disturbance (Grime 1979). Managers and researchers have used this scheme to identify ecosystem changes at the biogeographical scale, detect patterns in ant community responses to that change, and predict ant species distributions (Andersen 1995). 
Although species richness of Dominant Dolichoderine in North America is lower, comparisons have been drawn between Australian and North American ant fauna (Andersen 1997a) and the use of the functional group model has been employed successfully in many studies to assess ecosystem change (Andersen 1997a, Izhaki et al. 2001, Stephens and Wagner 2006, Underwood and Quinn 2010, Unstad 2012, Moranz et al. 2013). 
Table 1.1. Description of functional groups (Andersen 1995) and categorization of Missouri ant genera. Based on Andersen 1997 and Izhaki et al. 2003.

\begin{tabular}{|c|c|c|}
\hline Functional Group & Description & Missouri genera in group \\
\hline $\begin{array}{l}\text { Dominant } \\
\text { Dolichoderine } \\
\text { (DD) }\end{array}$ & $\begin{array}{l}\text { Species that are } \\
\text { aggressive and dominant } \\
\text { usually favoring hot } \\
\text { climates }\end{array}$ & Forelius \\
\hline $\begin{array}{l}\text { Subordinate } \\
\text { Camponotini (SC) }\end{array}$ & $\begin{array}{l}\text { Large nocturnal species } \\
\text { in the genus Camponotus } \\
\text { that are competitively } \\
\text { submissive to DD }\end{array}$ & Camponotus \\
\hline $\begin{array}{l}\text { Hot Climate } \\
\text { Specialists (HCS) }\end{array}$ & $\begin{array}{l}\text { Avoid DD and inhabit } \\
\text { xeric, hot areas }\end{array}$ & Solenopsis (subgenus Solenopsis) \\
\hline $\begin{array}{l}\text { Cold Climate } \\
\text { Specialists (CCS) }\end{array}$ & $\begin{array}{l}\text { Found in cooler climates } \\
\text { free of DD }\end{array}$ & $\begin{array}{l}\text { Tenmnothorax, Stenamma, Lasius, } \\
\text { Prenolepis, Formica (rufa group), } \\
\text { Protomognathus, Dolichoderus, }\end{array}$ \\
\hline $\begin{array}{l}\text { Tropical Climate } \\
\text { Specialists (TCS) }\end{array}$ & $\begin{array}{l}\text { Species found in warmer } \\
\text { tropical climatic } \\
\text { conditions with few DD }\end{array}$ & Neivamyrmex, Tribe Attini \\
\hline $\begin{array}{l}\text { Cryptic Species } \\
\text { (CS) }\end{array}$ & $\begin{array}{l}\text { Small bodied ants that } \\
\text { inhabit litter and soil with } \\
\text { little interaction with } \\
\text { other functional groups, } \\
\text { especially epagaeic } \\
\text { foragers }\end{array}$ & $\begin{array}{l}\text { Solenopsis (subgenus Diplorhoptum), } \\
\text { Hypoponera, Ponera, Brachymyrmex, } \\
\text { Strumigenys, Stigmatomma, Proceratium, }\end{array}$ \\
\hline Opportunists (OP) & $\begin{array}{l}\text { Rapid colonizers of } \\
\text { recently disturbed areas } \\
\text { with weak competitive } \\
\text { ability and a wide ranging } \\
\text { diet }\end{array}$ & $\begin{array}{l}\text { Myrmica, Formica (fusca group and } \\
\text { subgenera Raptiformica and Neoformica), } \\
\text { Nylanderia, Dorymyrmex, Tapinoma, } \\
\text { Tetramorium, Aphaenogaster, } \\
\text { Odontomachus }\end{array}$ \\
\hline $\begin{array}{l}\text { Generalized } \\
\text { Myrmicinae (GM) }\end{array}$ & $\begin{array}{l}\text { Species in the subfamily } \\
\text { Myrmicinae that recruit } \\
\text { other individuals to and } \\
\text { defend resources, } \\
\text { common in most habitats }\end{array}$ & Pheidole, Crematogaster, Monomorium \\
\hline $\begin{array}{l}\text { Specialized } \\
\text { Predators }\end{array}$ & $\begin{array}{l}\text { Large bodied ants that } \\
\text { specialize on other } \\
\text { organisms with little } \\
\text { interaction with other } \\
\text { groups }\end{array}$ & Polyergus \\
\hline
\end{tabular}

Ants as bioindicators of biodiversity and ecosystem health

Another useful tool for the assessment of biodiversity and ecosystem health is the use bioindicators (Noss 1990, Spellerberg 2005). According to Noss (1990), quality 
bioindicators should be sensitive to stress and disturbance, found across a biogeographical and stress gradient, easy and affordable to sample, and distinguishable between natural and anthropogenically disturbed habitats. Ants meet these requirements recommending them as biological indicators of ecosystem change (Andersen 1997b, Kaspari and Majer 2000, Andersen et al. 2002, Stephens and Wagner 2006, Underwood and Fisher 2006, Bennett et al. 2009, Andersen 2010, Fagan et al. 2010, Mitrovich et al. 2010, Gollan et al. 2011). In addition, studies have shown that ant assemblage recovery after disturbance mirrors community structure of the insect community as a whole (Andersen et al. 2004, Andersen 2010) and assemblage patterns of other animal and plant groups (Majer et al. 2007).

The trend of using ants in monitoring programs has caught on in Australia (Andersen and Majer 2004) with much research to support it (Andersen 1997b, King et al. 1998, de Bruyn 1999, Read and Andersen 2000, Andersen et al. 2002, Andersen et al. 2004, Bennett et al. 2009, Gollan et al. 2011), however, the United States and the rest of the world are slow to adopt and use ants as bioindicators. Studies in Australia, for instance, have evaluated the bioindicators value for ants in sites recovering from fire, flooding, pollution, grazing, agriculture, urbanization, silvicultural treatments and mining (Hoffman and Andersen 2003). Disturbances and other management treatments, like fire, are implemented and assessed for restoration of communities to pre-settlement conditions and control invasive species, yet invertebrates, save the most charismatic taxa, have been generally excluded from these evaluations. Some studies do exist however. In a study examining responses of ants to disturbance severity in a ponderosa pine forest in northern Arizona, Stephens and Wagner (2006) found unique indicators for each treatment; cold 
climate specialist, Lasius sp. was indicative of an unmanaged forest; Formica oreas and the opportunistic rufa group of Formica were found in thinned stands; Tapinoma sessile, an opportunist and Pheidole sp., a generalist, were found in stands affected by wildfire. Ottonetti et al. (2006) showed strong differences in indicator values in species sampled across a gradient of restored mine sites in the Mediterranean. In restored grasslands of England three species of ants were identified as bioindicators of remnant sites yet only one species was a prominent indicator of restored sites (Fagan et al. 2010). The Argentine Ant, Linepithema humile, an aggressive, invader that displaces native ant species, was detected as an indication of urban and agricultural sites in California and was associated with decreases in species richness of native ants (Mitrovich et al. 2010). The utility of ants as bioindicators has been repeatedly tested and could be implemented on a wider scale.

Response of ants to prescribed burning

The use of ants as bioindicators and in functional groups has contributed to the literature describing the responses of ant communities to prescribed fire, although other measurements are also applied. Research on the response of ants to disturbances like fire is commonplace in Australia. Hoffman and Andersen (2003) reviewed the effects of disturbance, including fire, on ant functional groups in Australia (Table 1.1); responses to prescribed fire varied but all responses tended to reflect physical changes induced by the disturbance. HCS and heat-loving DD increased after low to moderate intensity burns in closed forests because of increased sunlight and reduced litter and midstory trees (Hoffman and Andersen 2003). Areas with higher rainfall experience more OP after a 
disturbance and CS respond negatively to most disturbances (Hoffman and Andersen 2003).

Although responses of arthropods to prescribed fire have been fairly well researched in North America (Heyward and Tissot 1936, Metz and Farrier 1973, Siemann et al. 1997, McCullough et al. 1998, Bess 2000, Kalisz and Powell 2000, Niwa and Peck 2002, Adams and Rieske 2003, Hanula and Wade 2003, Dress and Boerner 2004, Coleman and Rieske 2006, Ferrenberg et al. 2006, Campbell et al. 2007, Kay et al. 2007), results of studies often reflect changes in biomass and diversity at the family level with little reference to ecological impact. By looking more specifically at ants, a more detailed ecological story is revealed; yet, studies documenting the effects of disturbances like fire on ant assemblages are lacking in the United States. The studies that exist are scattered across the country and with varying responses of ants to prescribed fire. In California, studies show a decrease in abundance of ants post fire, but distinct species composition based on changes to vegetation characteristics (Underwood and Quinn 2010, Matsuda et al. 2011). Verble (2012) looked at short-term responses of ants to prescribed fire in the Arkansas Ozarks and found decreased species richness, abundance and taxonomic similarity after fire. Samples were taken within only 2-6 months after burning and ant communities had little time to recover. Functional group responses in the United States are consistent with trends found in Australia (Hoffman and Andersen 2003). In burned and thinned / burned stands in Northern Arizona, GM and OP increased respectively post disturbance; functional group analyses were more telling than traditional diversity measurements (Stephens and Wagner 2006). When examining the effects of grazing and burning on ant assemblages in restored and remnant prairies, Moranz et al. (2013) 
reported an increase in OP and DD in burned restoration sites when higher numbers of SC and OP in remnant sites. Finally, in a long leaf pine stand in Florida DD were found in greater abundances after a fire where GM were severely affected by fire likely due to the increased competition pressure from the DD (Izhaki et al. 2001).

\section{Gaps in knowledge}

Owing to their vast contributions to ecosystem processes and health, it is essential that arthropods be considered in fire management plans. However, fire research in the Missouri Ozarks is devoid of studies regarding arthropods. A baseline must be developed with experimental studies to support the use of fire in regards to its effects on arthropod communities and their diversity. Ants are an excellent focal group for managers, as there exists much research supporting their inclusion as bioindicators in monitoring programs. Likewise there is ample life history information about North American species, easily implemented sampling protocols, clear identification keys, and functional group schemes that provide ecological information.

Restoration efforts are widespread in Missouri because many of the terrestrial natural communities are fire dependent (e.g. prairies, savannas, woodlands, glades). Ants likely played strong ecological roles in these systems and should therefore be incorporated into monitoring programs as bioindicators. Unlike plants that have a seed bank, it is difficult to determine historical species compositions of ants in Missouri's savannas, woodlands and forests; very few remnant habitats remain for comparison. However, it is likely that species that existed were tolerant or adapted to low to moderate intensity fires and were able to forage at higher temperatures due to increased insolation 
on the forest floor in woodlands and savannas. At a coarser scale, ants were, hypothetically, highly diverse due to the heterogeneous mosaic of natural communities that once covered the land. It is evident that seed dispersers, like those in the fulva-rudistexana complex of the genus Aphaenogaster and others, likely existed in the region historically because ant-dispersed plants are present in today's woodlands and forests. Still much information is lacking about the life history of ants that could help myrmecologists piece together historical compositions and in turn determine ants' ecological roles in the landscape. Other clues may arise through anthropological means. Jurney (2012) examined the contents of an elderly woman's stomach found at a burial site in the Ozarks and found several fire adapted plant species used as food and some insects within a fruit of one such plant, including an ant. Perhaps by combining anthropological efforts with life history traits, and composition of ants at remnant sites, we may more accurately assign indicator values to species and functional groups. Identifying indicator species of ants and other arthropods could be critical to restoring functional attributes to natural communities. Furthermore, use of ant functional groups has grown and patterns of functional responses to disturbance have become increasingly clear although research is still lacking.

It should be noted that the use of climate specialization and dominance in functional group schemes, descriptors based on ant responses to environmental gradients, disturbance, stress and competition, is most useful when comparing sites at a biogeographical scale. Finer scale ecological interactions go unnoticed under this scheme. For instance, some cryptic species, like those in the genus Strumigenys, feed on springtails, primitive insects that decompose organic matter; changes in their numbers 
may affect pedogenic processes. These subtler interactions go unnoticed under Andersen's scheme providing less detail about ecological processes that are occurring. In addition, the divisions of Andersen's functional groups are based on dominance. Dominance hierarchies are determined by observations at baiting traps; unless temporal variation in foraging activity is considered in these observations, certain species that exhibit dominance may go unnoticed. By applying multiple schemes, Australian functional groups (Andersen 1995) and categorizations that explore feeding strategies and/or nesting strategies, there is potential to compare biogeographical patterns at a coarse scale and finer scale ecological patterns that may answer site-specific questions about a community.

\section{Research objectives}

Many public and non-profit agencies have reintroduced fire to forested ecosystems in the Missouri Ozark Highlands to meet various management objectives. Regardless of these objectives the preservation of biodiversity contributes to the successful achievement of most sustainable forest management goals. By examining the effects of prescribed fire on ground-foraging ant assemblages and their contributions to ecosystem function, this study could provide data to aid managers in their implementation of burning in Missouri's forests.

This study aimed to examine the effects of prescribed fire on abundance, species diversity, and richness of ant assemblages in the Missouri Ozark Highlands region. Effects of prescribed fire on ant species composition is also assessed. Further, I explored the relationship of fire to functional diversity of ant assemblages at a fine scale through 
categorizations based on nesting behavior, in addition to the Andersen model (Andersen 1995). Use of the Andersen model added to the growing body of research incorporating this scheme. I examined fire-free intervals, duration of current fire regime and topographic aspect and slope position as independent variables.

Following this literature review and introduction (Chapter 1), Chapter 2 compares three fire regimes in the University Forest Conservation Area: annual prescribed fire, periodic prescribed fire, and unburned control. Ground-foraging ant assemblages were assessed for two years, for differences in abundance, diversity, richness, functional diversity, nesting preference, size and species composition.

Chapter 3 describes the results of prescribed fire on ground-foraging ant assemblages and their abundance, diversity, richness, functional diversity, nesting preference, size and species composition at Logan Creek and Clearwater Creek Conservation Areas, forest sites of an experimental treatment of prescribed burning. I considered the effects of aspect and slope position on assemblages.

Chapter 4 will synthesizes effects of prescribed burning on ant communities in forests of the Missouri Ozark Highlands. Attention focuses on trends in biological and functional diversity measurements, ecological interactions and management recommendations. 


\section{Literature Cited}

Abrams, M. D. 1992. Fire and the development of oak forests. BioScience 42:346-353.

Adams, A. S. and L. K. Rieske. 2003. Prescribed fire affects white oak seedling phytochemistry: implications for insect herbivory. Forest Ecology and Management 176:37-47.

Alexander, J. D., N. E. Seavy, C. J. Ralph, and B. Hogoboom. 2006. Vegetation and topographical correlates of fire severity from two fires in the Klamath-Siskiyou region of Oregon and California. International Journal of Wildland Fire 15:237245.

Andersen, A. N. 1991. Responses of ground-foraging ant communities to three experimental fire regimes in a savanna forest of tropical Australia. Biotropica 23:575-585.

Andersen, A. N. 1995. A classification of Australian ant communities, based on functional group which parallel plant life-forms in relation to stress and disturbance. Journal of Biogeography 22:15-29.

Andersen, A. N. 1997a. Functional groups and patterns of organization in North American ant communities: a comparison with Australia. Journal of Biogeography 24:433-460.

Andersen, A. N. 1997b. Using ants as bioindicators: multiscale issues in ant community ecology. Conservation Ecology (online) 1:8.

Andersen, A. N. 2010. Functional groups in ant community ecology Pages 142-144 in L. Lach, C. L. Parr, and K. L. Abbott, editors. Ant Ecology. Oxford University Press, Oxford, England.

Andersen, A. N., A. Fisher, B. D. Hoffman, J. L. Read, and R. Richards. 2004. Use of terrestrial inverstebrates for biodiversity monitoring in Australian rangelands, with particular reference to ants. Austral Ecology 29:87-92.

Andersen, A. N., B. D. Hoffman, W. J. Muller, and A. D. Griffiths. 2002. Using ants as bioindicators in land management: simplifying assessment of ant community responses. Journal of Applied Ecology 39:8-17.

Andersen, A. N. and J. D. Majer. 2004. Ants show the way Down Under: invertebrates as bioindicators in land management. Frontiers in Ecology and Environment 2:291298. 
Arthur, M. A., H. D. Alexander, D. C. Dey, C. J. Schweitzer, and D. L. Loftis. 2012. Refining the oak-fire hypothesis for manaagement of oak-dominated forests of the eastern United States. Journal of Forestry 110:257-266.

Beattie, A. J. and D. C. Culver. 1977. Effects of mound nests of the ant, Formica obscuripes, on the surrounding vegetation. American Midland Naturalist 97:390399.

Beattie, A. J. and D. C. Culver. 1981. The guild of myrmecochores in the herbaceous flora of West Virginia forests. Ecology 62:107-115.

Bell, A. L. 2007. The effects of fire management on avian species in Missouri Ozark glade-woodland habitats. M.S. thesis, University of Michigan. 96p.

Bennett, J. M., A. S. Kutt, C. N. Johnson, and S. K. A. Robson. 2009. Ants as indicators for vertebrate fauna at a local scale: an assessment of cross-taxa surrogacy in a disturbed matrix. Biodiversity and Conservation 18:3407-3419.

Bess, J. 2000. Fire Bugs.in Workshop on fire, people, and the central hardwoods landscape. USDA Forest Service, Richmond, KY.

Bolton, B., G. Alpert, P. S. Ward, and P. Naskrecki. 2006. Bolton's catalogue of ants of the world. Pages CD-ROM. Harvard University Press, Cambridge, MA.

Brian, M. V. and A. D. Brian. 1951. Insolation and ant populations in the west of Scotland. Transactions of the Royal Entomological Society of London 102:303330 .

Brisson, J. A., J. L. Strasburg, and A. R. Templeton. 2003. Impact of fire management on the ecology of collared lizard (Crotaphytus collaris) populations living on the Ozark Plateau. Animal Conservation 6:247-254.

Campbell, J. W., J. L. Hanula, and T. A. Waldrop. 2007. Effects of prescribed fire and fire surrogates on floral visiting insects of the blue ridge province in North Carolina. Biological Conservation 134:393-404.

Campbell, K. U., H. Klompen, and T. O. Crist. 2013. The diversity and host specificity of mites associated with ants: the roles of ecological and life history traits of ant hosts. Insectes Sociaux 60:31-41.

Coleman, T. W. and L. K. Rieske. 2006. Arthropod response to prescription burning at the soil litter interface in oak-pine forests. Forest Ecology and Management 233:52-60.

Coovert, G. A. 2005. The Ants of Ohio (Hymenoptera: Formicidae). Ohio Biological Surver, Inc., Columbus, $\mathrm{OH}$. 
Culver, D. C. and A. J. Beattie. 1978. Myrmechory in Viola: dynamics of seed-ant interactions in some West Virginia species. Journal of Ecology 66:53-72.

Cutter, B. E. and R. P. Guyette. 1994. Fire frequency on an oak-hickory ridgetop in the Missouri Ozarks. American Midland Naturalist 132:393-398.

de Bruyn, L. A. L. 1999. Ants as bioindicators of soil function in rural environments. Agriculture, Ecosystems and Environment 74:425-441.

Delcourt, P. A., G. R. Wilkins, and E. N. Smith. 1986. Vegetational histroy of the cedar glades regions of Tennessee, Kentucky and Missouri during the past 30,000 years. A.S.B. Bulletin 33:128-137.

Dey, D. C. and G. W. Hartman. 2005. Returning fire to Ozark Highland forest ecosystems: effects on advance regeneration. Forest Ecology and Management 217:37-53.

Dress, W. J. and R. E. J. Boerner. 2004. Patterns of microarthropod abundance in oakhickory forest ecosystems in relation to prescribed fire and landscape position. Pedobiologia 48:1-8.

Fagan, K. C., R. F. Pywell, J. M. Bullock, and R. H. Marrs. 2010. Are ants useful indicators of restoration success in temperate grasslands? . Restoration Ecology 18:373-379.

FAO. 2009. Forest fires and the law: A guide for national drafters based on the Fire Management Voluntary Guidelines. Food and Agriculture Organization.

FAO. 2011. Promoting sustainable forest management.

Farji-Brener, A. G., J. C. Corley, and J. Bettinelli. 2002. The effects of fire on ant communities in north-western Patagonia: the importance of habitat structure and regional context. Diversity and Districutions 8:235-243.

Ferganani, P. N., P. Sackmann, and A. Ruggiero. 2013. The spatial variation in ant species compostion and functional groups across the Subanarctic-Patagonian transition zone. Journal of Insect Conservation 17:295-305.

Ferrenberg, S. M., D. W. Schwilk, E. E. Knapp, E. Groth, and J. E. Keeley. 2006. Fire decreases arthropod abundance but increases diversity: early and late season prescribed fire effects in a Sierra Nevada mixed-conifer forest. Fire Ecology 2:79102.

Fisher, B. L. and S. P. Cover. 2007. Ants of North America: A Guide to the Genera. University of California Press, Los Angeles, CA. 
Folgarait, P. J. 1998. Ant diversity and its relationship to ecosystem functioning: a review. Biodiversity and Conservation 7:1221-1244.

Fralish, J. S. 2004. The keystone role of oak and hickory in the central hardwood forest.in Upland Oak Ecology Symposium. USDA Forest Service, Asheville, NC.

Gaston, K. J. 1991. The magnitude of global insect species richness Conservation Biology 5:283-296.

Gaston, K. J. 1992. Regional numbers of insct and plant species. Functional Ecology 6 243-247.

Godwin, D.S. 2013. Trends in prescribed in Missouri. Tallgrass Prairie and Oak Savanna Fire Science Consortium Regional Fire Conference. Dubuque, IA. January 2013.

Gollan, J. R., L. L. d. Bruyn, N. Reid, D. Smith, and L. Wilkie. 2011. Can ants be used as ecological indicators of restoration progress in dynamic environments? A case study in a revegetated riparian zone. Ecological Indicators 11:1517-1525.

Grime, J. P. 1979. Plant Strategies, Vegetation Processes, and Ecosystem Properties. John Wiley, Chichester, UK.

Guyette, R. P. and B. E. Cutter. 1991. Tree-ring analysis of fire histroy of a post oak savanna in the Missouri Ozarks. Natural Areas Journal 11:93-99.

Guyette, R. P. and B. E. Cutter. 1997. Fire history, population, and calcium cycling in the Current River Watershed.in Proceedings, 11th Central Hardwood Conference; Columbia, MO. Gen. Tech. Rep. NC-188. St. Paul, MN: Department of Agriculture, Forest Service, North Central Forest Experiment Station: 354-372.

Guyette, R. P. and D. C. Dey. 2000. Humans, topography, and wildland fire: the ingredients for long-term patterns in ecosystems. Pages 28-35 in Workshop on Fire, People and the Central Hardwoods Landscape. USDA Forest Service, Richmond, KY.

Guyette, R. P. and J. M. Kabrick. 2002. The legacy and continuity of forest disturbance, succession, and species at the MOFEP sites.in Proceedings of the Second Missouri Ozark Forest Ecosytem Project Symposium: Post-treatment Results of the Landscape Experiment. Gen. Tech. Rep. NC-227. St. Paul, MN: U.S. Department of Agriculture, Forest Service, North Central Experiment Station. pp. 26-44.

Guyette, R. P., R. M. Muzika, and D. C. Dey. 2002. Dynamics of an anthropogenic fire regime. Ecosystems 5:472-486. 
Guyette, R. P. and M. A. Spetich. 2003. Fire history of oak-pine forests in the lower Boston Mountains, Arkansas, USA. Forest Ecology and Management 180:463474.

Guyette, R. P., M. C. Stambaugh, and R. M. Muzika. 2006. Fire scars reveal variability and dynamics of easter fire regimes. Pages 20-39 in Fire in Eastern Oak Forests: Delivering Science to Land Managers. USDA Forest Service, Columbus, OH.

Hanula, J. L. and D. D. Wade. 2003. Influence of long-term dormant-season burning and fire exclusion on ground-dwelling arthropod populations in longleaf pine flatwoods ecosystem. Forest Ecology and Management 175:163-184.

Hartman, G. W. 2005. Forest land management guide: use of prescribed fire. Pages 1-9. Missouri Department of Conservation, Columbia, MO.

Heithaus, E. R. 1981. Seed predation by rodents on three ant-dispersed plants. Ecology 62:136-145.

Heyward, F. and A. N. Tissot. 1936. Some changes in the soil fauna associated with forest fires in the longleaf pine region. Ecology 17:659-666.

Higashi, S. and K. Yamauchi. 1979. Influence of a supercolonial ant Formica (Formica) yessensis Forel on the distribution of other ants in Ishikari Coast. Japanese Journal of Ecology 29:257-264.

Hoffman, B. D. and A. N. Andersen. 2003. Responses of ants to disturbance in Australia, with particular reference to functional groups. Austral Ecology 28:444-464.

Hölldobler, B. and E. O. Wilson. 1990. The Ants. The Belknap Press of Harvard University Press, Cambridge, MA.

Izhaki, I., D. J. Levey, and W. R. Silva. 2001. Effects of prescribed fire on an ant community in Florida pine savanna. Ecological Entomology 28:439-448.

Jenkins, S. E., R. P. Guyette, and A. J. Rebertus. 1997. Vegetation-site relationships and fire history of a savanna-glad-woodland mosaic in the Ozarks. Pages 184-201 in Central Hardwood Forest Conference, St. Paul, MN.

Jurney, D. H. 2012. Anthropology of fire in the Ozark Highland region.in 4th Fire in Eastern Oak Forests Conference, Springfield, MO.

Kalisz, P. J. and J. E. Powell. 2000. Effects of prescribed fire on soil inverstebrates in upland forests on the Cumberland Plateau o Kentucky, USA. Natural Areas Journal 20:336-341. 
Kaspari, M. 2000. Primer on ant ecology. Pages 9-24 in D. Agosti, J. D. Majer, L. E. Alonso, and T. R. Schultz, editors. Ants: standard methods for measuring and monitoring biodiversity Smithsonian Institute Press, Washington, D.C.

Kaspari, M. and J. D. Majer. 2000. Using ants to monitor environmental change. Pages 89-98 in D. Agosti, J. D. Majer, L. E. Alonso, and T. Shultz, editors. Ants: standard methods for measuring and monitoring biodiversity. Smithsonian Institution Press, Washington, DC.

Kay, A. D., J. D. Schade, M. Ogdahl, E. O. Wesserle, and S. E. Hobbie. 2007. Fire effects on insect herbivores in an oak savanna: the role of light and nutrients. Ecological Entomology 32.

Keyser, P. D. and W. M. Ford. 2006. Influence of fire on mammals in eastern oak forest. Pages 180-190 in Fire in eastern oak forests: delivering science to land managers, proceedings of a conference. United States Department of Agriculture, Forest Service, Northern Research Station, Newtown Square, PA. Gen. Tech Report, NRS-P-1:1-XX.

King, J. R., A. N. Andersen, and A. D. Cutter. 1998. Ants as bioindicators of habitat disturbance: validation of the functional group model for Australia's humid tropics. Biodiversity and Conservation 7:1627-1638.

Kinkead, C. 2013. Thinning and burning in oak woodlands. M.S.Thesis. University of Missouri, Columbia, MO. 125p.

Kronauer, D. J. C. and N. E. Pierce. 2011. Myrmecophiles. Current Biology 21:R208209.

Lach, L., C. L. Parr, and K. L. Abbott. 2010. Preface. Page 402 in L. Lach, C. L. Parr, and K. L. Abbott, editors. Ant Ecology. Oxford University Press, Oxford, England.

Ladd, D. 1991. Reexaminaation of the role of fire in Missouri oak woodlands. Pages 6780 in Oak Woods Management Workshop, Eastern Illinois University, Charleston, IL.

Lawton, J. 1994. What do species do in ecosystems? . Oikos 71:364-374.

Lindenmayer, D. B., C. R. Margules, and D. B. Botkin. 2000. Indicators of biodiversity for ecologically sustainable forest management. Conservation Biology 14:941950.

Lowenstein, E. F., K. W. Grabner, and G. W. Hartman. 2002. Integrating fuel and forest management: developing prescriptions for the central hardwoods region. United States Forest Service, Columbia, MO. 
MacKay, W. P. and E. E. MacKay. 2002. The ants of New Mexico (Hymenoptera: Formicidae). Edwin Mellen Press, New Mexico.

MacKay, W. P., A. Rebeles, H. Arredondo, A. Rodriguez, D. Gonzalez, and B. Vinson. 1991. Impact of slashing and burning of a tropical rain forest on the native ant fauna (Hymenoptera: Formicidae). Sociobiology 18:257-268.

Majer, J. D., G. Orabi, and L. Bisevac. 2007. Ants (Hymenoptera: Formicidae) pass the bioindicator scorecard. Myrmecological News 10:69-76.

Marshall, D. L., A. J. Beattie, and W. E. Bollenbacher. 1979. Evidence for diglycerides as attractants in an ant-seed interaction Journal of Chemical Ecology 5:335-344.

Matsuda, T., G. Turschak, C. Brehme, C. Rochester, M. Mitrovich, and R. Fisher. 2011. Effects of large-scale wildfires on ground foragin ants (Hymenoptera: Formicidae) in Southern California Environmental Entomology 40:204-216.

May, R. M. 1988. How many species are there on Earth? . Science 247:1441-1449.

McCarty, K. 1998. Landscape-scale restoration in Missouri savannas and woodlands. Restoration and Management Notes 161:22-32.

McCullough, D. G., R. A. Werner, and D. Neumann. 1998. FIre and insects in Northern and boreal forest ecosystems of North America. Annual Review of Entomology 43:107-127.

Metz, L. J. and M. H. Farrier. 1973. Prescribed burning and populations of soil mesofauna. Environmental Entomology 2:433-440.

Mitrovich, M. J., T. Matsuda, K. H. Pease, and R. N. Fisher. 2010. Ants as a measure of effectiveness of habitat conservation planning in southern California. Conservation Biology 24:1239-1248.

Moranz, R. A., D. M. Debinski, L. Winkler, J. Trager, D. A. McGranahan, D. M. Engle, and J. R. Miller. 2013. Effects of grassland management practices on ant functional groups in central North America. Journal of Insect Conservation 17:699-713.

Naeem, S. and S. Li. 1997. Biodiversity enhances ecosystem reliability. Nature 390:507509.

The Nature Conservancy. The Nature Conservancy's Chilton Creek Management Area: a case study of the effects of fire-based ecosystem management in the Missouri Ozarks. The Nature Conservancy, Van Buren, MO. 8pp. 
Nelson, P. W. 2005. The Terrestrial Natural Communities of Missouri. Missouri Natural Areas Committee, Jefferson City, MO.

Ness, J. H., D. F. Morin, and I. Giladi. 2009. Uncommon specialization in a mutualism between a temperate herbaceous plant guild and an ant: are Aphaenogaster rudis ants keystone mutualists? . Oikos 118:1793-1804.

Nigh, T. A. 1992. The forests prior to European settlement. Pages 6-13 in A. R. P. Journet and H. G. Spratt, editors. Towards a vision for Missouri's public forests. Southeast Missouri State Unviversity, Cape Girardeau, MO.

Niwa, C. G. and R. W. Peck. 2002. Influence of prescribed fire on Carabid beetle (Carabidae) and spider (Araneae) assemblages in forest litter in Southwestern Oregon. Community and Ecosystem Ecology 31:785-796.

Noss, R. F. 1990. Indicators for monitoring biodiversity: a hierarchical approach. Conservation Biology 4:355-364.

Nowacki, G. J. and M. D. Abrams. 2008. The demise of fire and "mesophication" of forests in the eastern United States. BioScience 58:123-138.

Odegaard, F. 2000. How many species of arthropods are there? Erwin's estimate revised. Biological Journal of the Linnean Society 71:583-597.

Ottonetti, L., L. Tucci, and G. Santini. 2006. Recolonization patterns of ants in a rehabilitated lignite mine in central Italy: potential for use of Mediterranean ants as indicators of restoration processes. Restoration Ecology 14:60-66.

Pallardy, S. G., T. A. Nigh, and H. G. Garrett. 1988. Changes in forest composition in Central Missouri: 1968-1982. American Midland Naturalist 120:380-390.

Parr, C. L. and H. Gibb. 2010. Competition and the role of dominant ants. Pages 77-96 in L. Lach, C. L. Parr, and K. L. Abbott, editors. Ant Ecology. Oxford University Press, Oxford, UK.

Petchey, O. L. and K. J. Gaston. 2002. Functional diversity (FD), species richness and community composition. Ecology Letters 5:402-411.

Phillips, R., T. F. Hutchinson, L. Brudnak, and T. Waldrop. 2007. Fire and fire surrogate treatments in mixed-oak forests: effects on herbaveous layer vegetation.in Proceedings of the conference the fire envrionment--innovations, management and policy. 26-30 March, 2007; Destin, FL. U.S. Department of Agriculture, Forest Service, Rochky Mountain Research Station. RMRS-P-46CD. 
Philpott, S. M., I. Perfecto, I. Armbrecht, and C. L. Parr. 2010. Ant diversity and function in disturbed and changing habitats. Pages 137-156 in L. Lach, C. L. Parr, and K. L. Abbott, editors. Ant Ecology. Oxford University Press, Oxford, England.

Price, P. W. 2002. Species interactions and the evolution of biodiversity in C. M. Herrera and O. Pellmyr, editors. Plant-Animal Interactions: An Evolutionary Approach. Blackwell Science Oxford.

Pudlo, R. J., A. J. Beattie, and D. C. Culver. 1980. Population consequences of changes in ant-seed mutualism in Sanguinaria canadensis. Oecologia 46:32-37.

Pyne, S. 1984. Introduction to Wildland Fires: Fire Management in the United States. John Wiley, New York, NY.

Read, J. L. and A. N. Andersen. 2000. The value of ants as ealy warning bioindicators: responses to pulsed cattle grazing at an Australian arid zone locality. Journal of Arid Environments 45:231-251.

Rico-Gray, V. and P. S. Oliveira. 2007. The Ecology and Evolution of Ant-Plant Interactions. The University of Chicago Press, Chicago, IL.

Roman-Cuesta, R. M., M. Gracia, and J. Retana. 2009. Factors influencing the formation of unburned forest islands within the perimeter of a large forest fire. Forest Ecology and Management 258:71-80.

Samways, M. J., M. A. McGeoch, and T. R. New. 2010. Insect Conservation: A Handbook of Approaches and Methods. Oxford University Press, Oxford, England.

Sauer, C. O. 1920. The geography of the Ozark Highlands of Missouri. Geographic Society of Chicago Bulletin. University of Chicago Press, Chicago, IL.

Scholwater, T. D. 2011. Insect Ecology: An ecosystem approach. 3rd edition. Elesevier/Academic San Diego, CA.

Siemann, E., J. Haarstad, and D. Tilman. 1997. Short-term and long-term effects of burning on oak savanna arthropods. American Midland Naturalist 137:349-361.

Spellerberg, I. 2005. Monitoring Ecological Change. Cambridge University Press, New York.

Stambaugh, M. C. and R. P. Guyette. 2006. Fire regime of an Ozark wilderness area, Arkansas. American Midland Naturalist 156:237-251.

Stephens, S. and L. W. Ruth. 2005. Federal forest-fire policy in the United States. Ecological Applications 15:532-542. 
Stephens, S. S. and M. R. Wagner. 2006. Using ground foraging ant (Hymenoptera: Formicidae) functional groups as bioindicators of forest health in northern Arizona ponderosa pine forests. Community and Ecosystem Ecology 35:937-949.

Strausberg, S. and W. A. Hough. 1997. The Ouachita and Ozark-St.Francis National Forests: a history of the lands and USDA Forest Service tenure. USDA Forest Service Gen. Tech. Rep. SO-121, Asheville, NC.

Strysky, J. D. and M. D. Eubanks. 2007. Ecological consequences of interactions between ants and honeydew-producing insects. Proceedings of the Royal Society of Biology 274:151-164.

Thompson, J. N. 1981. Elaiosomes and fleshy fruits: phenology and selection pressures for ant-dispersed seeds. American Naturalist 117:104-108.

Tilman, D. 2001. Functional diversity. Pages 109-120 in S. A. Levin, editor. Encyclopedia of biodiversity. Academic Press, San Diego, CA.

Underwood, E. C. and B. L. Fisher. 2006. The role of ants in conservation monitoring: If, when, and how. Biological Conservation 132:166-182.

Underwood, E. C. and J. F. Quinn. 2010. Response of ants and spiders to prescribed fire in oak woodlands of California. Journal of Insect Conservation 14:359-366.

Unstad, K. 2012. Predictors of insect diversity and abundance in a fragmented tallgrass prairie ecosystem. M.S. Thesis.University of Nebraska, Lincoln, NE.

USDA Forest Service Daniel Boone National Forest. 2005. Land and resource management plan for the Daniel Boone National Forest. Manag. Bull. R8-MB $125 \mathrm{~A}$.

USDA Forest Service Mark Twain National Forest. 2005. Land and resource management plan for the Mark Twain National Forest. Available online at www.fs.fed.us/r9/forest/marktwain/projects/forest_plan/; last accessed Sep. 14, 2013.

Verble, R. M. 2012. Effects of prescribed fire on Ozark ant ecology. Ph. D. Dissertation. University of Arkansas-Little Rock.

Weatherspoon, C. P. and C. N. Skinner. 1995. An assessment of factors associated with damage to the tree crowns form the 1987 wildfires in northern California. Forest Science 41:430-451.

Wehner, R. A., C. Marsh, and S. Wehner. 1992. Desert ants on a thermal tightrope. Nature 357:586-587. 
Wheeler, W. M. 1930. The ant Prenolepis imparis Say. Annals of the Entomological Society of America 23:1-26.

Whelan, R. J. 1995. The Ecology of Fire. Cambridge University Press, Camridge, UK.

Wilson, E. O. 1959. Some ecological characteristics of ants in New Guinea rain forests. Ecology 40:437-447.

Wright, L. W. 2013. Ground-dwelling arthropods in burned and unburned forest in the Missouri Ozark Highlands. Unpublished data. 


\section{CHAPTER 2. EFFECTS OF OVER 60 YEARS OF PRESCRIBED BURNING ON ANT FORAGING ACTIVITY AND ECOLOGICAL FUNCTION}

\section{Introduction}

After decades of fire suppression, prescribed burning has been implemented in the United States to reach a variety of management goals: reduce fuel loading to prevent high intensity wildfires, eradicate invasive species, recover and maintain wildlife habitat, promote the reproductive success of high quality tree species, and increase biodiversity (McCarty 1998, Nelson 2005). All of these objectives are employed in the Missouri Ozark Highlands where fire has been primarily used to encourage the regeneration and growth of oak (Quercus, species) and pine (Pinus echinata) and restore woodlands and savannas that were once more common in the state (McCarty 1998, Dey and Hartman 2005).

It is widely accepted among researchers and land managers alike that many Midwestern oak-dominated natural communities are fire-adapted and have developed with anthropogenic and natural fires for millennia (Ladd 1991, Nigh 1992, Guyette and Dey 2000, Guyette et al. 2002, Jurney 2012). Oaks have thick bark that is resistant to fire, the ability to resprout after a disturbance (Abrams 1992) and leaves that curl and cure when they senesce creating fuel that readily ignites. Furthermore, the plant communities associated with oak-dominated forests and woodlands contain a diverse array warm season grasses, sedges and forbs (McCarty 1998). Since fire suppression, however, fireintolerant species (e.g. maple, elm, hackberry, ash) have been encroaching on oak forests, modifying forest structure and tree species composition (Pallardy et al. 1988, Nowacki 
and Abrams 2008) and shading ground flora that depend on the canopy openings provided in a low-stocked woodland or savanna (McCarty 1998, Taft 2009, Kinkead 2013). It is now widely recognized that fire sculpted Missouri's landscapes and state and, consequently, federal agencies currently implement its use statewide.

Reinstating fire in a forested landscape has led to questions about fire's effects on natural communities and the biota associated with these forests. Fire increases the diversity of ground flora and frequency of conservative species in oak forests (McCarty 1998, Taft 2009). Taft (2009) reported significantly higher herbaceous layer diversity in burned areas where overstory stocking levels were lowest. The highly conservative herbaceous species, Tall Larkspur (Delphinium exaltatum) shows a trend of positive responses in response to prescribed fire (Christine Steinwand, personal communication). The effects of fire on forest structure vary, attracting different suites of bird species to burned and unburned forests (Blake 2005, Bell 2007). The collared lizard, e.g. a species of conservation concern, is a glade obligate needing open woodlands and savannas for migration among sub-populations (Templeton et al. 2001); Brisson et al. (2003) assessed dispersal of these lizards through burned and unburned forests, and found in higher densities in burned forest corridors.

Abundance, diversity and ecological contribution notwithstanding, arthropods have been considered very little in fire research in Missouri. Ants, in particular, make up a third of the biomass of all insects (Wilson and Hölldobler 2005) with over 12,500 (Lach et al. 2010) species known to science and over 140 species in Missouri (Trager 2013), and therefore occupy a diversity of ecological niches. They are considered ecological engineers for their contributions to nutrient cycling and soil aeration (Folgarait 1998). 
Ants are used as indicators of ecosystem change in monitoring programs worldwide because they are relatively easy and inexpensive to sample, are highly sensitive to disturbance, and are abundant (King et al. 1998, Kaspari and Majer 2000, Andersen et al. 2002, Andersen et al. 2004, Underwood and Fisher 2006). As a tool to help understand the ecological consequences of disturbance, changes in distribution of ants, and biogeographical differences in ant community composition, a functional group model has been developed and widely used to characterize ant assemblages (Andersen 1995, 1997, Hoffman and Andersen 2003, Andersen 2010).

Although the study of ecological effects of prescribed fire has received increasing attention in recent years, the experimental approach to evaluating these effects generally include only recently implemented studies. There are, therefore, few sites to evaluate long-term fire data. An exception is the University Forest Conservation Area (UFCA) near Wappappello, Missouri. This site is unique in that fire has been implemented there experimentally since 1949 - a time during which most of the state was "protected" from destructive wildfires. Very few experimental forests exist that have been treated consistently with fire for over sixty years. This forest provides a unique opportunity to examine long-term changes in the forest structure, nutrient cycles, and floral and faunal communities as affected by fire. There have been very few studies on these sites, however. Paulsell (1957) and Scowcraft (1966) found that higher fuel loads in periodic burns (burned every 4 years) increased mortality of trees. Specifically, mortality occurs in hickories, red oaks and seedlings of red oaks and maples, while white oaks and post oaks seem unchanged across treatments (Huddle and Pallardy 1996, 1999). 
The study presented here uses the long-term treatments at UFCA to examine the effects of two prescribed fire regimes (e.g. annual and periodic fire) on ground foraging ant assemblage composition, diversity, richness and abundance in comparison with unburned control forests. Further, I explore changes in the dynamics of ant functional groups, size classes, and nesting groups and individual species.

Internationally, the use of ants has gained popularity in monitoring programs, but few incorporate ants in the United States (Izhaki et al. 2001, Stephens and Wagner 2006, Underwood and Quinn 2010, Matsuda et al. 2011, Unstad 2012, Verble 2012). Most studies demonstrate an initial decrease in abundance of ants after a fire with differing abundances and species composition where vegetation has been significantly altered (Underwood and Quinn 2010, Matsuda et al. 2011, Verble 2012). Functional groups when employed in the United States, show similar patterns to those found in Australia with increased abundances in GM, OP and DD in response to fire (Izhaki et al. 2001, Stephens and Wagner 2006, Moranz et al. 2013). These studies, however, examine effects of fire regimes that have been in place over the short term. I hypothesize that sixty years of repeated fires will alter the physical characteristics of these forests with distinct assemblages in each treatment. The consequences of long-term implementation of prescribed fire on ant assemblages may provide insight into alterations in the complex interactions of ants with their environment and with the biotic community. 


\section{Methods}

Study site

This study was conducted at UFCA in Butler Co., Missouri $\left(36^{\circ} 55^{\prime} \mathrm{N}, 90^{\circ} 15^{\prime} \mathrm{W}\right)$, approximately, 9 kilometers east of Wappapello, MO in the southeastern Missouri Ozark Highlands (Fig. 2.1). It is located in the Black River Ozark Border subsection of the Missouri ecoregions, which once was dominated by short leaf pine, pine-oak woodlands, post oak flatwoods, and mixed bottomland forests (Nigh and Schroeder 2002). Although most of the short leaf pine has been logged, today the area consists of secondary oakhickory and oak-pine forests (Huddle and Pallardy 1996, Nigh and Schroeder 2002). The site itself is located in the Wappapello oak-pine woodland/forest hills landtype association (Nigh and Schroeder 2002). The karst landscape is rich with springs, streams and rivers that occupy the valleys of the Ozark hills. Although the fire frequency in the area is unknown, mean fire-free intervals in the proximate Current River Hills Subsection range from 17.7 years before 1700 to 3.7 years before 1940 when the region was subject to a regime of fire suppression (Guyette and Cutter 1997). The UFCA served as an educational and research station for the University of Missouri School of Forestry, Fisheries and Wildlife initiated in1947. In 1988, much of the acreage was purchased by the Missouri Department of Conservation and is currently managed by the agency (Missouri Department of Conservation 2012). Comprising 7,149 acres, the area's dominant tree species include Quercus alba, Quercus stellata, Quercus velutina, Quercus coccinea, Carya spp., Acer spp. and Pinus echinata in the overstory and Cornus florida, Sassafrass albidum, Nyssa sylvatica, Diospyros virginana, among other species in the understory (Huddle and Pallardy 1996, 1999, Stephan 2010, unpublished raw data, 
Missouri Department of Conservation 2012). Herbaceous plant communities are mostly characterized by common species found in the Ozarks like Parthenocissus quinquefolia, Toxicodendron radicans, Panicum spp., Rubus spp., Vaccinium spp., and some species found in dry-mesic woodlands and forests like Helianthus hirsutus, Aristolochia serpentaria, Danthonia spicata, Lespedeza spp., Desmodium spp., and Carex spp. (Stephan 2010, unpublished raw data). The area supports characteristic Ozark wildlife like the white-tailed deer, wild turkey and the pileated woodpecker. Average maximum temperatures reach 20.39 degrees Celsius, with minimum temperatures of 8.22 degrees Celsius, and $118 \mathrm{~cm}$ of annual precipitation (High Plains Regional Climate Center, Wappapello Dam, MO 2013).
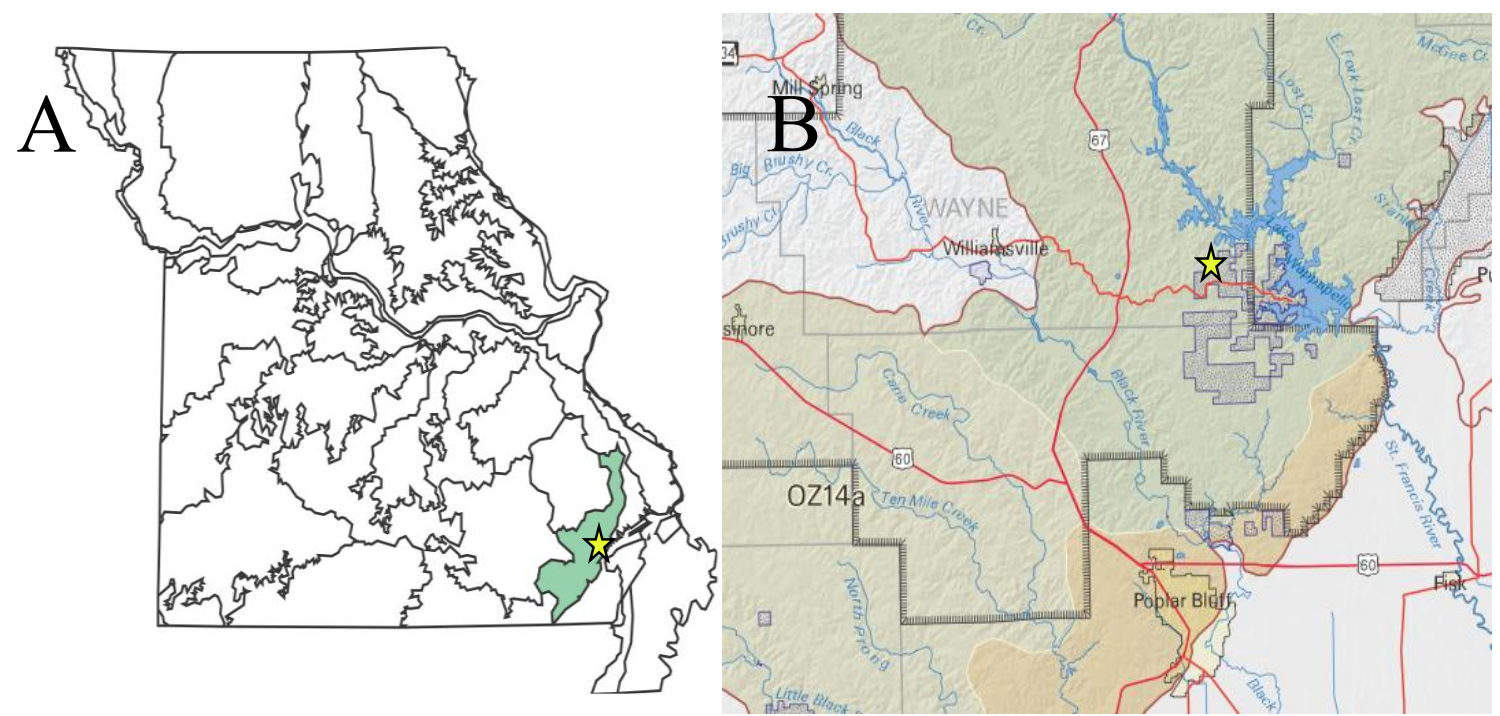

Fig. 2.1. A) University Forest Conservation Area located in the Black River Ozark Border subsection in the southeastern corner of the Missouri Ozark Highlands. B) The Wappapello Oak-Pine Woodland/Forest Hills are the associated land types in the region (Nigh and Schroeder 2002). 


\section{Experimental design}

Within UFCA, two 1.25 ha blocks (F1 and F2, approximately 90x140m²), each arranged in a 2x3 grid of 6 plots measuring 40x40m were established in 1949 and 1951 , respectively, in order to determine the effects of "fire protection" on wood quality. Since data now support the use of prescribed fire in forest management in the region, this study gives researchers a unique perspective on fire's long-term effects when forests are burned at regular intervals. The first established block was a well-stocked, oak-hickory forest and the second, an oak-hickory, upland flatwoods characterized by a fragipan, a subsurface clay layer that constricts water drainage and root growth (Huddle and Pallardy 1996, 1999). Neither site had been burned for at least 20 years and grazing had been excluded for at least 15 years at the time of establishment. Each block contains two annually burned (fire interval = 1 year), periodically burned (fire interval $=4$ years), and control plots that have been randomly assigned within the $2 \times 3$ grid of each block (Fig. 2.2). Each plot is $40 \mathrm{~m} \times 40 \mathrm{~m}$ with a $10.1 \mathrm{~m}$ buffer. Annual plots are burned yearly and periodic plots burn every 4 years; periodic plots of F1 last burned in the spring of 2009 and those of F2 in spring of 2011. Some details of each prescribed fire events since 1997 are outlined in Table 2.1.

\section{Ant Sampling}

In the last week of June of 2011 and 2012, pitfall traps were installed along 5 transects that bisected each plot: 2 transects from west to east and 3 from north to south (Fig. 2.2). One trap was placed $5 \mathrm{~m}$ from the plot edge and then every ten meters; additionally one pitfall trap was placed between plots in order to describe edge effects. A 
total of 110 traps were deployed per year. Traps, consisting of two plastic soup cups $(\sim 500 \mathrm{~mL})$, were placed flush with the ground, one set inside the other with $200 \mathrm{~mL}$ of propylene glycol as a killing agent and preservative for specimens. The top cup served as the collecting receptacle and the bottom maintained the hole, dug with a post-hole digger) to decrease impacts on the surrounding environment from repeated use. They were then covered with a plastic plate and affixed with 2-3 nails to prevent rainwater from entering. Traps were left open for 2 weeks and collected in early July each year. Pitfall traps are recommended as a sampling technique for evaluating land management decisions (Underwood and Fisher 2006). Passive sampling techniques like this one stay in one place and capture any ground-foraging ants wandering past; for this reason they also provide better estimates of species richness than other methods (e.g. bait trapping, litter collection) (Bestelmeyer et al. 2000).
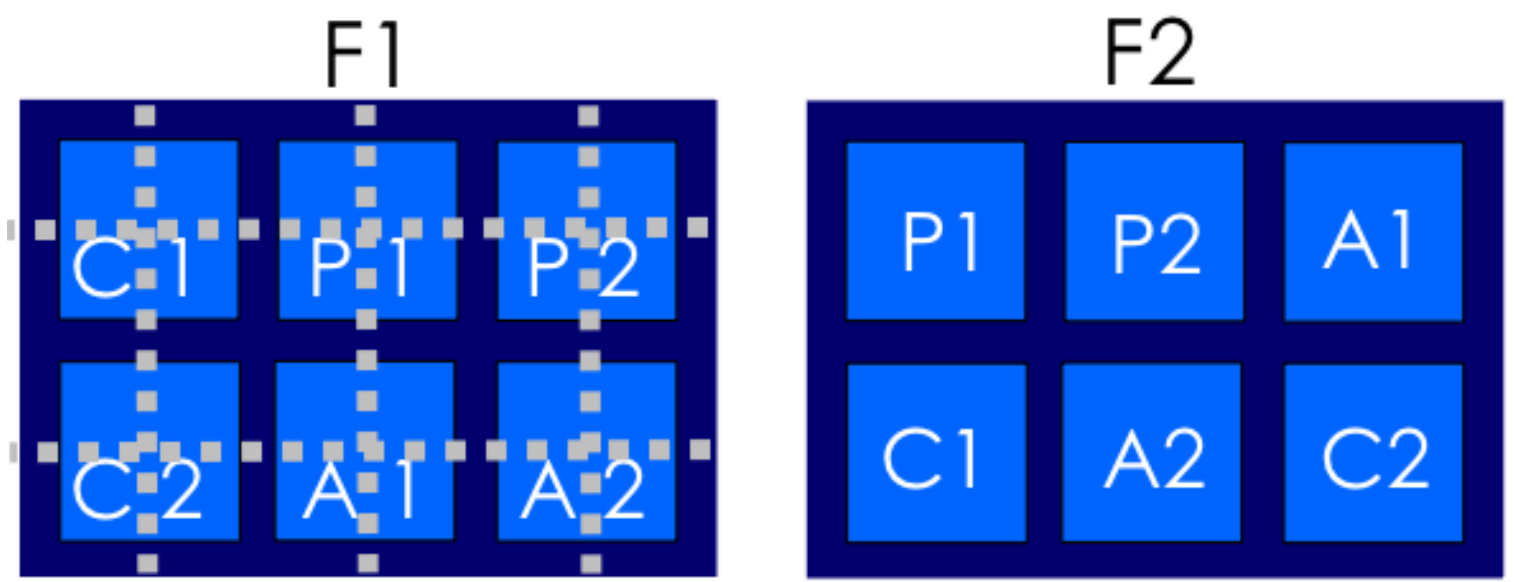

Fig. 2.2. Randomized block design at the University Forest Conservations Area. F1(left), was a well stocked oak-hickory forest pretreatment and shows location of pitfall traps in grey. F2 (right) is an upland flatwoods with oak-hickory pretreatment forest composition. $\mathrm{C}=\mathrm{Control}, \mathrm{A}=$ Annual, $\mathrm{P}=$ Periodic. Numbers indicate plot number. 
Table 2.1. Prescribed burn records from the University Forest Conservation Area experimental burn plots from 1997 to 2013 including climatic characteristics and burn notes (Courtesy of Mark Pelton, Missouri Department of

Conservation).

\begin{tabular}{|c|c|c|c|c|c|c|c|c|c|}
\hline Year & Block & $\begin{array}{c}\text { Date } \\
\text { (Month } \\
\text { /Year) }\end{array}$ & Annual & Periodic & Temp & $\begin{array}{c}\text { Relative } \\
\text { Humidity } \\
(\%)\end{array}$ & $\begin{array}{l}\text { Wind speed } \\
\quad(\mathrm{mph})\end{array}$ & $\begin{array}{c}\text { Wind } \\
\text { Direction }\end{array}$ & Burn Notes \\
\hline \multirow[t]{2}{*}{1997} & $\mathrm{~F} 1$ & 2-May & yes & yes & 17.2 & 24 & 5 & 135 & hot burn \\
\hline & $\mathrm{F} 2$ & 2-May & yes & no & 18.3 & 20 & 5 & 180 & hot burn \\
\hline \multirow[t]{2}{*}{1998} & $\mathrm{~F} 1$ & 10-Apr & yes & no & 11.1 & 29 & 5 & 200 & hot burn \\
\hline & $\mathrm{F} 2$ & 10-Apr & yes & no & 13.8 & 24 & 7-Jan & 200 & hot burn \\
\hline \multirow[t]{2}{*}{1999} & $\mathrm{~F} 2$ & 20-Apr & yes & yes & 17.2 & 27 & 5 & 350 & hot burn \\
\hline & $\mathrm{F} 1$ & 20-Apr & yes & no & 17.2 & 38 & 5 & 350 & medium \\
\hline \multirow[t]{2}{*}{2000} & $\mathrm{~F} 1$ & N/A & yes & no & N/A & N/A & N/A & N/A & $\begin{array}{c}\text { burned, but lost data } \\
\text { sheet }\end{array}$ \\
\hline & $\mathrm{F} 2$ & N/A & yes & no & N/A & N/A & N/A & N/A & $\begin{array}{c}\text { burned, but lost data } \\
\text { sheet }\end{array}$ \\
\hline \multirow[t]{2}{*}{2001} & $\mathrm{~F} 1$ & N/A & N/A & yes & N/A & N/A & N/A & N/A & $\begin{array}{c}\text { burned, but lost data } \\
\text { sheet }\end{array}$ \\
\hline & $\mathrm{F} 2$ & N/A & yes & no & N/A & N/A & N/A & N/A & $\begin{array}{c}\text { burned, but lost data } \\
\text { sheet }\end{array}$ \\
\hline \multirow[t]{2}{*}{2002} & $\mathrm{~F} 1$ & N/A & yes & no & N/A & N/A & N/A & N/A & $\begin{array}{c}\text { burned, but lost data } \\
\text { sheet }\end{array}$ \\
\hline & $\mathrm{F} 2$ & N/A & yes & no & N/A & N/A & N/A & N/A & $\begin{array}{c}\text { burned, but lost data } \\
\text { sheet }\end{array}$ \\
\hline \multirow[t]{2}{*}{2003} & $\mathrm{~F} 2$ & 14-Apr & yes & yes & 15.5 & 32 & $8 \mathrm{mph}$ & 225 & hot burn \\
\hline & $\mathrm{F} 1$ & 15-Apr & yes & no & 22.7 & $35 \%$ & 8 & 180 & cool burn \\
\hline
\end{tabular}




\begin{tabular}{|c|c|c|c|c|c|c|c|c|c|}
\hline 2004 & F2 & 8-Mar & yes & no & 17.2 & 26 & 7 & 245 & $\begin{array}{c}\text { good fuel } \\
\text { consumption }\end{array}$ \\
\hline & F1 & 8-Mar & yes & no & 18.3 & 22 & 10 & 235 & $\begin{array}{l}\text { good fuel } \\
\text { consumption }\end{array}$ \\
\hline \multirow[t]{2}{*}{2005} & $\mathrm{~F} 1$ & 18-Apr & yes & yes & 16.1 & 28 & 5 & 70 & $\begin{array}{l}\text { good fuel } \\
\text { consumption }\end{array}$ \\
\hline & $\mathrm{F} 2$ & 18-Apr & yes & no & 18.3 & 24 & 6 & 270 & $\begin{array}{l}\text { good fuel } \\
\text { consumption }\end{array}$ \\
\hline \multirow[t]{2}{*}{2006} & $\mathrm{~F} 1$ & 15-Mar & yes & no & 15.5 & 20 & 7 & 225 & hot burn \\
\hline & $\mathrm{F} 2$ & 28-Mar & yes & no & 14.4 & 45 & 7 & 300 & medium burn \\
\hline \multirow[t]{2}{*}{2007} & $\mathrm{~F} 1$ & 5-Apr & yes & no & 15.5 & 35 & 8 & 85 & cool burn \\
\hline & $\mathrm{F} 2$ & 5-Apr & yes & yes & 16.6 & 30 & 10 & 90 & cool burn \\
\hline \multirow[t]{2}{*}{2008} & $\mathrm{~F} 1$ & 30-Apr & yes & no & 18.8 & 25 & 5 & 180 & green, cool burn \\
\hline & $\mathrm{F} 2$ & 30-Apr & yes & no & 20.5 & 26 & 4 & 180 & green, cool burn \\
\hline \multirow[t]{2}{*}{2009} & $\mathrm{~F} 1$ & 16-Apr & yes & yes & 13.8 & 50 & 9 & 55 & very cool, spotty burn \\
\hline & $\mathrm{F} 2$ & 16-Apr & yes & no & 15.5 & 42 & 9 & 55 & $\begin{array}{l}\text { good fuel } \\
\text { consumption }\end{array}$ \\
\hline \multirow[t]{2}{*}{2010} & $\mathrm{~F} 2$ & 24-Mar & yes & no & 18.8 & 40 & 13 & 176 & $\begin{array}{l}\text { good fuel } \\
\text { consumption }\end{array}$ \\
\hline & $\mathrm{F} 1$ & 30-Mar & yes & no & 18.8 & 40 & 9 & 184 & cool burn \\
\hline \multirow[t]{2}{*}{2011} & $\mathrm{~F} 1$ & 13-Apr & yes & no & 22.2 & 50 & 4 & 35 & cool burn \\
\hline & $\mathrm{F} 2$ & 15-Apr & yes & yes & 23.8 & 40 & 7 & 135 & $\begin{array}{l}\text { good fuel } \\
\text { consumption }\end{array}$ \\
\hline \multirow[t]{2}{*}{2012} & $\mathrm{~F} 1$ & 2-Apr & yes & no & 29.4 & 52 & 5 & 45 & cool patchy burn \\
\hline & $\mathrm{F} 2$ & 2-Apr & yes & no & 24.4 & 63 & 5 & 45 & very cool, spotty burn \\
\hline \multirow[t]{2}{*}{2013} & $\mathrm{~F} 1$ & 13-Apr & yes & yes & 19.4 & 45 & 4 & 35 & medium burn \\
\hline & $\mathrm{F} 2$ & 13-Apr & yes & no & 22.2 & 35 & 5 & 40 & $\begin{array}{l}\text { good fuel } \\
\text { consumption }\end{array}$ \\
\hline
\end{tabular}




\section{Sample Processing}

Samples were taken back to the lab where specimens were strained through a fine mesh net to separate arthropods from dirt and small debris. Specimens were preserved in 80\% ethanol and distilled water solution. Ants were sorted from other arthropods, identified to species whenever possible, and counted. Ants of the genus Solenopsis were treated as one group as they were abundant, very minute and made up only two possible species with similar ecological behavior. Species Aphaenogaster caroleninsis and the undescribed species temporarily named Aphaenogaster n19 (n19 refers to the chromosomal number of its haploid karyotype, see Umphrey (1996) for more details), are currently in a state of taxonomic flux, and were therefore lumped as well. Voucher specimens were confirmed for correct identification by James Trager of the Missouri Botanical Gardens and will be deposited in the MU Entomology Museum.

\section{Functional Groups}

Ants were classified into functional groups following Andersen (1997).

Functional groups provide a better understanding of the ecology and distribution of ant assemblages at a biogeographical scale (Andersen 1995). Classifications are based on Grime (1979) and his treatment of plant function with respect to stress, disturbance and competition. Andersen (1995) argues that ant colonies are more similar to plants than other organisms because they are mostly sedentary, they send out foragers to feed the colony like rhizomes searching for soil nutrients, and they send out "propagules" or queens to establish colonies elsewhere. The functional groups are Dominant Dolichoderine (DD), Generalized Myrmicinae (GM), Subordinate Camponotini (SC), 
Opportunists (OP), Hot Climate Specialists (HCS), Cold Climate Specialists (CCS),

Tropical Climate Specialists (TCS), Cryptic (CR) and Specialized Predators (SP) (Table

2.2). These groupings reflect the influence of interspecific competition, stress and

disturbance that may influence community composition and distribution.

Table 2.2. Functional groups used in this study and their descriptions based on Andersen (1995).

\begin{tabular}{|l|l|}
\hline Functional Group & \multicolumn{1}{|c|}{ Description } \\
\hline $\begin{array}{l}\text { Subordinate } \\
\text { Camponotini (SC) }\end{array}$ & $\begin{array}{l}\text { Large nocturnal species in the genus Camponotus that are } \\
\text { competitively submissive to DD }\end{array}$ \\
\hline $\begin{array}{l}\text { Cold Climate } \\
\text { Specialists (CCS) }\end{array}$ & Found in cooler climates free of DD \\
\hline $\begin{array}{l}\text { Tropical Climate } \\
\text { Specialists (TCS) }\end{array}$ & Species found in warmer tropical climatic conditions with few DD \\
\hline $\begin{array}{l}\text { Cryptic Species } \\
\text { (CR) }\end{array}$ & $\begin{array}{l}\text { Small bodied ants that inhabit litter and soil with little interaction } \\
\text { with other functional groups, especially epagaeic foragers }\end{array}$ \\
\hline Opportunists (OP) & $\begin{array}{l}\text { Rapid colonizers of recently disturbed areas with weak competitive } \\
\text { ability and a wide ranging diet }\end{array}$ \\
\hline $\begin{array}{l}\text { Generalized } \\
\text { Myrmicinae (GM) }\end{array}$ & $\begin{array}{l}\text { Species in the subfamily Myrmicinae that recruit other individuals } \\
\text { to and defend resources, common in most habitats }\end{array}$ \\
\hline $\begin{array}{l}\text { Specialized } \\
\text { Predators (SP) }\end{array}$ & $\begin{array}{l}\text { Large bodied ants that specialize on other organisms with little } \\
\text { interaction with other groups }\end{array}$ \\
\hline
\end{tabular}

Nesting behavior and size classes

To better understand local ecological dynamics of ground foraging ant assemblages, ant species were categorized into size groups, small (S), medium (M) and large (L), and nesting behavior groups, arboreal (AR), cavity/litter (CL), soil (SO), and wood (WO) (Table 2.3). Both size and nesting behavior were determined by exploring 
available literature and keys that provide information on total body length and compiled observations of nest sites for each species (Creighton 1950, Coovert 2005, Snelling and Snelling 2007, Trager et al. 2007, Kallal and LaPolla 2012, MacGown 2013). Ant size ranges were averaged and ranked; ants with an average size of $<3.49 \mathrm{~mm}$ were considered small (S), 3.5-5.99mm were medium (M) and $>6 \mathrm{~mm}$ were considered large (L). Those ant species that build nests in trees were considered arboreal (AR), those species that inhabit pre-existing cavities and the litter-soil interface were considered cavity/litter nesters (CL), those that build nests and reside in the ground were categorized as soil nesters (SO), and those that nest almost exclusively in course woody debris were wood nesters (WO).

Table 2.3. Subfamilies and species found at University Forest Conservation Area and their corresponding functional group, nesting group, and size class designations.

\begin{tabular}{|l|l|c|c|c|}
\hline Subfamily & Species & $\begin{array}{c}\text { Functional } \\
\text { Group }\end{array}$ & $\begin{array}{c}\text { Nesting } \\
\text { Group }\end{array}$ & $\begin{array}{c}\text { Size } \\
\text { Class }\end{array}$ \\
\hline Amblyoponinae & Stigmatomma pallipes Haldeman & CR & CL & M \\
\hline Dolichoderinae & Tapinoma sessile Say & OP & CL & S \\
\hline Ecitoninae & Neivamyrmex opacithorax Emery & TCS & CL & S \\
\hline Formicinae & Brachymyrmex depilis Emery & CR & CL & S \\
\hline & Camponotus americanus Mayr & SC & SO & L \\
\hline & Camponotus castaneus Latreille & SC & SO & L \\
\hline & Camponotus chromaioides Bolton & SC & WO & L \\
\hline & Camponotus nearcticus Emery & SC & AR & M \\
\hline & Camponotus obliquus Smith & SC & AR & M \\
\hline & $\begin{array}{l}\text { Camponotus pennsylvanicus } \\
\text { DeGreer }\end{array}$ & SC & AR & L \\
\hline & Camponotus snellingi Bolton & SC & AR & M \\
\hline & Camponotus subarbatus Emery & SC & SO & M \\
\hline & Formica dolosa Buren & OP & SO & L \\
\hline & Formica pallidefulva Latreille & OP & SO & M \\
\hline & Formica rubicunda Emery & OP & SO & L \\
\hline & Formica subintegra Emery & OP & SO & L \\
\hline & Formica subsiricea Say & OP & SO & L \\
\hline & Nylanderia faisonensis Forel & OP & CL & S \\
\hline & $\begin{array}{l}\text { Nylanderia trageri } \text { Kallal and } \\
\text { LaPolla }\end{array}$ & OP & CL & S \\
\hline & Polyergus longicornis Smith* & SP & SO & L \\
\hline & Prenolepis imparis Say & CCS & SO & M \\
\hline & Aphaenogaster fulva Roger & OP & CL & M \\
\hline Myrmicinae
\end{tabular}




\begin{tabular}{|c|c|c|c|c|}
\hline & Aphaenofaster lamellidens Mayr & OP & WO & $\bar{M}$ \\
\hline & Aphaenogaster mariae Wheeler & OP & $\mathrm{AR}$ & $\mathrm{M}$ \\
\hline & $\begin{array}{l}\text { Aphaenogaster carolinensis } \\
\text { Wheeler and Aphaenogaster } \mathrm{n}=19 \text {, } \\
\text { see Umphrey (1996) }\end{array}$ & OP & $\mathrm{WO} / \mathrm{SO}$ & $\bar{M}$ \\
\hline & $\begin{array}{l}\text { Aphaenogaster tennesseeinsis } \\
\text { Mayr }\end{array}$ & OP & AR & M \\
\hline & Aphaenogaster treatae Forel & OP & SO & $\mathrm{L}$ \\
\hline & Crematogaster ashmeadi $\mathrm{Mayr}$ & GM & $\mathrm{AR}$ & $\mathrm{S}$ \\
\hline & Crematogaster lineolata Say & GM & $\mathrm{SO}$ & M \\
\hline & Monomorium minimum Buckley & GM & SO & $\mathrm{S}$ \\
\hline & Myrmecina americana Emery & CCS & CL & $\mathrm{S}$ \\
\hline & Myrmica americana Weber & $\mathrm{OP}$ & SO & M \\
\hline & Myrmica pinetorum Wheeler & OP & SO & M \\
\hline & Myrmica punctiventris Roger & OP & CL & M \\
\hline & Pheidole bicarinata Mayr & GM & $\mathrm{SO}$ & $\mathrm{S}$ \\
\hline & Pheidole dentata Mayr & GM & $\mathrm{SO}$ & $\mathrm{S}$ \\
\hline & Pheidole pillifera Roger & GM & $\mathrm{SO}$ & $\mathrm{S}$ \\
\hline & Pheidole tysoni Forel & GM & $\mathrm{SO}$ & $\mathrm{S}$ \\
\hline & $\begin{array}{l}\text { Protomognathus americanus } \\
\text { Emery }\end{array}$ & CCS & $\mathrm{CL}$ & $\mathrm{S}$ \\
\hline & $\begin{array}{l}\text { Solenopis molesta Say and } S \text {. } \\
\text { texana Forel }\end{array}$ & $\mathrm{CR}$ & SO & $\mathrm{S}$ \\
\hline & Stenamma diecki Emery & CCS & SO & $\mathrm{S}$ \\
\hline & Stenamma impar Forel & $\mathrm{CCS}$ & SO & $\mathrm{S}$ \\
\hline & Strumigenys louisianae Roger* & $\mathrm{CR}$ & SO & $\mathrm{S}$ \\
\hline & Strumigenys ornata Mayr & $\mathrm{CR}$ & CL & $\mathrm{S}$ \\
\hline & Strumigenys talpa Weber & $\mathrm{CR}$ & CL & $\mathrm{S}$ \\
\hline & Temnothorax curvispinosus Mayr & $\mathrm{CCS}$ & CL & $\mathrm{S}$ \\
\hline & Temnothorax pergandei Roger & CCS & SO & $\mathrm{S}$ \\
\hline & Temnothorax schaumii Roger & CCS & AR & $\mathrm{S}$ \\
\hline & Temnothorax texanus Wheeler & CCS & SO & $\mathrm{S}$ \\
\hline & $\begin{array}{l}\text { Trachymyrmex septentrionalis } \\
\text { McCook }\end{array}$ & TCS & SO & $\mathrm{M}$ \\
\hline Ponerinae & Hypoponera opacior Forel & $\mathrm{CR}$ & WO & $\mathrm{S}$ \\
\hline & Ponera exotica Smith & $\mathrm{CR}$ & CL & $\mathrm{S}$ \\
\hline & Ponera pennsylvanica Buckley & $\mathrm{CR}$ & SO & $\mathrm{S}$ \\
\hline Proceratiinae & Proceratium crassicorne Emery & $\mathrm{CR}$ & $\mathrm{SO}$ & $\mathrm{S}$ \\
\hline
\end{tabular}

\section{Statistical Analysis}

\section{Diversity and Abundance}

Individuals of each species were counted and then pooled for each plot. These abundances were used to calculate Shannon-Weiner Diversity, Simpson's Diversity and Evenness indices (Table 2.4). Because some traps were lost due to rain, total plot 
abundances were then divided by the number of traps in each plot. Asymptotic species richness estimators were calculated to extrapolate total species richness of the site (Chao 1984, Shen et al. 2003, Chao et al. 2006, Gotelli et al. 2011, Gotelli and Ellison 2013) using the Chao1 index in Species Prediction And Diversity Estimation software (SPADE, Chao and Shen 2010) although observed species richness was also analyzed. The Chao1 index uses singletons (species that occur exactly once in an assemblage) and doubletons (species that occur exactly twice in an assemblage) to estimate total species richness. Observed frequency of rare species reflects the number of rare species that were likely missed due to sampling effort, meaning that it is not possible to sample all ants at a site (Gotelli and Ellison 2013). To account for this, rare species (species that occurred less than ten times) were also recorded and analyzed. It should be noted that the Chao1 Index is a minimum asymptotic estimator and the true species richness of the site is likely greater than or equal to the projected value.

Table 2.4. List of indices used to assess diversity of ant assemblages at the University Forest Conservation Area.

\begin{tabular}{|c|c|}
\hline \multicolumn{2}{|c|}{ Diversity Indices } \\
\hline Shannon-Weiner Diversity Index & $H=-\sum_{i=1}^{S} p_{i} \ln p_{i}$ \\
\hline Simpson's Diversity Index & $D=\sum_{i=1}^{S} p_{i}^{2}$ \\
\hline Species Evenness Index & $E_{v a r}=1-2 / \pi \arctan \left\{\sum_{s=1}^{S}\left(\ln \left(x_{s}\right)-\sum_{t=1}^{S} \ln \left(x_{t}\right) / S\right)^{2} / S\right\}$ \\
\hline Chao1 Index & $\begin{aligned} \mathrm{S}_{\mathrm{obs}}+f_{1}^{2} / 2 f_{2} \text { if } f_{2}>0 & \text { and } \mathrm{S}_{\mathrm{obs}}+f_{1}\left(f_{1}-1\right) / 2\left(\mathrm{f}_{2}+1\right) \\
& \text { if } f_{2}=0\end{aligned}$ \\
\hline Chao2 Index & $\begin{array}{c}\mathrm{S}_{\mathrm{obs}}+(\mathrm{R}-1 / \mathrm{R})\left(q_{1}^{2} / 2 q_{2}\right) \text { if } q_{2}>0 \text { and } \\
\mathrm{S}_{\mathrm{obs}}++(\mathrm{R}-1 / \mathrm{R}) q_{1}\left(q_{1}-1\right) / 2\left(q_{2}+1\right) \text { if } q_{2}=0\end{array}$ \\
\hline
\end{tabular}


All diversity measures were tested for differences between year, block and treatment using mixed models, repeated measures Analysis of Variance (ANOVA) (PROC MIXED). Goodness of fit of models was determined using Akaike Information Criterion. Random effects included block and plot; treatment was considered a fixed effect. Plots and treatment were nested within block. Least squared means and their differences were calculated. Data were tested for normal distributions (Skewness and Kurtosis) and homogeneity among variances (PROC GLM: Bartlett's Test of Homogeneity, SAS Institute, Inc. 2012) and were log or rank transformed when assumptions of normality were not met (Conover and Iman 1981). Ranking data created homogeneity among variances of response variables when other transformations failed to do so. All statistical analyses were performed with SAS 9.2 and 9.3 (SAS Institute, Inc. 2012).

Functional groups, size class, nesting groups, and species

The most abundant species, functional groups, size classes and nesting group abundances per trap were sorted, rank transformed (Conover and Iman 1981) and the data tested for differences between years, blocks and treatments using a mixed models, repeated measures ANOVA with treatment as a fixed effect and block and plot as random effects; plot and treatment were nested within block. Least squared (LS) means and differences between LS means were calculated for each species, functional group, size class, and nesting group.

Ant assemblages across treatments and years were assessed using multiple incidence-based Morisita Similarity, an index that uses the shared species among multiple 
communities to compare the similarity of those communities (Chao et al. 2008) using SPADE software (Chao and Shen 2010). This index assesses more than two communities at a time using all shared information between assemblages. Species data were further analyzed using Multi-Response Permutation Procedures (MRPP) and Nonmetric Multidimensional Scaling using PC-ORD, v. 6.0 (McCune and Mefford 1999) to show overall community responses to treatments. The nonparametric analysis, MRPP, is used to distinguish differences in composition of two or more communities within a priori groups like treatment assemblages (Mielke and Berry 2001). This procedure can be performed when data do not meet assumptions of normality (Zimmerman et al. 1985), a common scenario with ecological community data. This method uses a test statistic (T) to calculate between group or treatment separation (the more negative a value signifies a greater degree of separation). An agreement statistic (A) evaluates within group homogeneity (when $\mathrm{A}=1$ communities are perfectly similar). P-values are generated using the Pearson type III distribution based on the test statistic. I tested the null hypothesis that there was no difference among transformed abundances of species and species composition among treatments with the Sorensen similarity index. In order to minimize sampling bias of pitfall traps placed near a nest or foraging trail, abundances were transformed using a 6 point index (Andersen 1991, 1997). This index uses classes to correspond to the following abundances: 0 ants $=0,1$ ant $=1,2-5$ ants $=2,6-10$ ants $=3,11-$ 20 ants $=4,21-50$ ants $=5,>50$ ants $=6$. To illustrate the findings of the MRPP, I used NMS to explore dissimilarity between communities using the Sorensen coefficient. NMS uses an iterative technique to plot data based on ranked distances or dissimilarities between treatments in k-dimensional space. The measure of the departure from monotonicity in 
the relationship between dissimilarity of actual space and reduced ordinational space is called "stress". Stress averages from 0-100 and the lower the stress, the more related to original ranked distances and the better the representation of dissimilarity between treatments.

\section{Buffers}

Buffer traps were assigned a category based on the adjacent burn treatments; categories were annual-annual (BAA), annual-control (BAC), annual-periodic (BAP), control-control (BCC), control-periodic (BCP), and periodic-periodic (BPP). Since each block has a different arrangement of treatments there are unequal observations for each buffer categorization. Therefore data were converted to presence/absence and species richness estimates using the Chao2 index (Table 2.4, see above). Similarity measurements using incidence-based Sorensen similarity index were calculated using SPADE (Chao and Shen 2010). The Chao 2 index differs from the Chao 1 in that it uses incidence-based data counting uniques and duplicates (species that occur in exactly one and two samples, respectively) instead of abundance data (Gotelli and Ellison 2013). Non-metric multidimensional scaling (NMS) was also used to examine dissimilarity between categories (see above description).

\section{Results}

\section{Diversity and Abundance}

A total of 26,337 ants among 54 species were collected and identified with buffer traps accounting for 3,381 individuals. Three species never before documented in Missouri were also found (James Trager, personal communication): Nylanderia trageri, 
Polyergus longicornis, and Strumigenys louisianae. There were more ants collected in 2012 than 2011 (p=0.045) (Fig. 2.3). Annual burns yielded a higher abundance than both control and periodic burns and there were significant differences among treatment by block interactions; annual burns in block F1 contained significantly more ants than the controls $(\mathrm{p}=0.0013)$ and the periodic burns $(\mathrm{p}=0.0022)$. In block $\mathrm{F} 2$, annuals were marginally different from controls $(\mathrm{p}=0.0525)$ and periodic burns $(\mathrm{p}=0.0881)$. Annual burns were different from each other, however, when compared between blocks F1 and $\mathrm{F} 2(\mathrm{p}=0.0079)$.
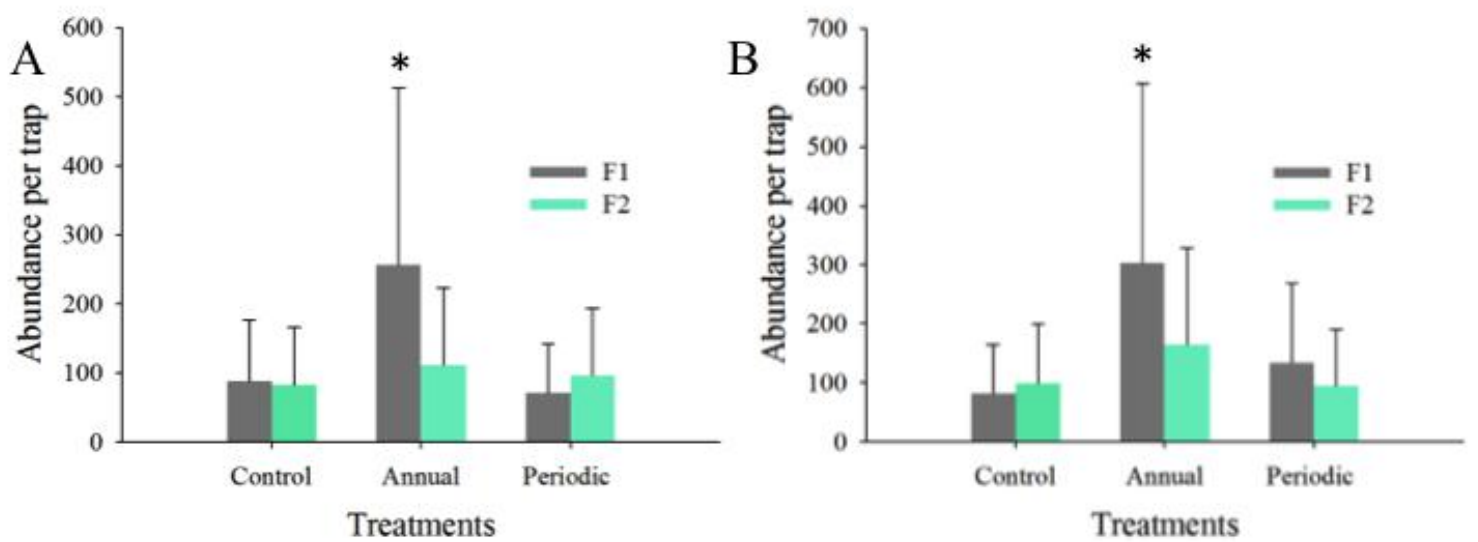

Fig. 2.3. Total abundance per trap of all ants across all treatments and blocks (mean +1 standard error) in A) 2011 and B) 2012.

There was an interaction between year and treatment for observed species richness (Table 2.5). Richness was higher in annual plots in 2012 than 2011 ( $\mathrm{p}=0.006)$ but richness was lower in controls in 2012 compared with 2011 ( $\mathrm{p}=0.0358$ ). In 2011, controls had higher species richness than annual burns $(\mathrm{p}=0.033)$ but the opposite was true in $2012(\mathrm{p}=0.0222)$. The Chao1 abundance-based asymptotic species estimator resulted in similar estimates across treatments, block and year with no significant effects (Table 2.5). Marginal differences were found in rare species among year, block and 
treatment interactions $(\mathrm{p}=0.0512)$ and treatment by year interactions $(\mathrm{p}=0.0389)$. The most rare species were found in annual plots in $2012(\mathrm{p}=0.0224)$; fewer were found in 2011 in annual plots most likely due to sampling effort (in 2011 six annual traps had been destroyed compared to one in 2012). Annual ( $\mathrm{p}=0.0188)$ and periodic plots $(\mathrm{p}=0.0416)$ also yielded significantly higher rare species that controls in 2012 (Table 2.5).

Table 2.5. Diversity measures of ant assemblages by year and treatment.

\begin{tabular}{|l|l|l|l|l|l|l|l|}
\hline Year & Treatment & $\begin{array}{l}\text { Observed } \\
\text { Species } \\
\text { Richness }\end{array}$ & $\begin{array}{l}\text { Chao1 } \\
\text { Index }\end{array}$ & $\begin{array}{l}\text { Rare } \\
\text { Species } \\
(<\mathbf{1 0})\end{array}$ & $\begin{array}{l}\text { Shannon- } \\
\text { Weiner } \\
\text { Index* }\end{array}$ & $\begin{array}{l}\text { Simpson's } \\
\text { Index** }\end{array}$ & $\begin{array}{l}\text { Evenness } \\
\text { Index*** }\end{array}$ \\
\hline $\mathbf{2 0 1 1}$ & Control & 26.25 & 39.925 & 14.00 & 1.9101 & 0.1309 & 0.2354 \\
\hline $\mathbf{2 0 1 1}$ & Annual & 21.75 & 29.850 & 11.75 & 1.8830 & 0.2392 & 0.2003 \\
\hline $\mathbf{2 0 1 1}$ & Periodic & 24.25 & 30.525 & 14.00 & 2.2904 & 0.1327 & 0.2815 \\
\hline $\mathbf{2 0 1 2}$ & Control & 23.50 & 31.475 & 11.25 & 1.9062 & 0.1718 & 0.2467 \\
\hline $\mathbf{2 0 1 2}$ & Annual & 28.50 & 31.075 & 16.50 & 2.0729 & 0.9203 & 0.1302 \\
\hline $\mathbf{2 0 1 2}$ & Periodic & 26.25 & 31.450 & 15.50 & 2.2958 & 0.7485 & 0.2044 \\
\hline
\end{tabular}

*The higher the index value the more diverse.

**The lower the index value the more diverse.

$* * *$ The lower the index value the lower the evenness.

Other diversity measures that were compared include Shannon-Weiner, Simpson's diversity indices and evenness (Table 2.5). Treatment had a marginal effect $(\mathrm{p}=0.0559)$ on Shannon-Weiner diversity with higher diversity in periodic burns compared with annual burns $(\mathrm{p}=0.0507)$ and controls $(\mathrm{p}=0.0280)$. Year $(\mathrm{p}=0.0079)$ and treatment affected Simpson's diversity most significantly between annual plots and controls $(\mathrm{p}=0.0091)$. There was a significant interaction between treatment and year for evenness (Table 2.5). 


\section{Functional groups}

Functional groups were numerically different in their composition in each treatment and the results of the mixed model analysis on functional groups revealed significant effects for five out of the seven individual groups (Fig. 2.4). CCS were found most commonly in control plots (treatment effect $\mathrm{p}=0.0175$ ) and in the year 2012 $(\mathrm{p}=0.0023)$. Annual and periodic plots, however, harbored more $\mathrm{CR}(\mathrm{p}=0.0145)$ and these species were significantly more numerous in 2012 than $2011 \mathrm{p}=0.0137)$. GM contain Monomorium minimum and Pheidole spp. that monopolized annual burns, and results showed significantly larger numbers of this functional group in annual burns $(\mathrm{p}=0.0195)$. The year 2012 yielded a significantly greater abundance of OP $(p=0.0169)$ although treatment and block had no effect. SC were more abundant in $2012(\mathrm{p}=0.0 .0085)$ and in control plots (treatment effect $\mathrm{p}=0.0104)$. SP and TCS showed no significant effects.
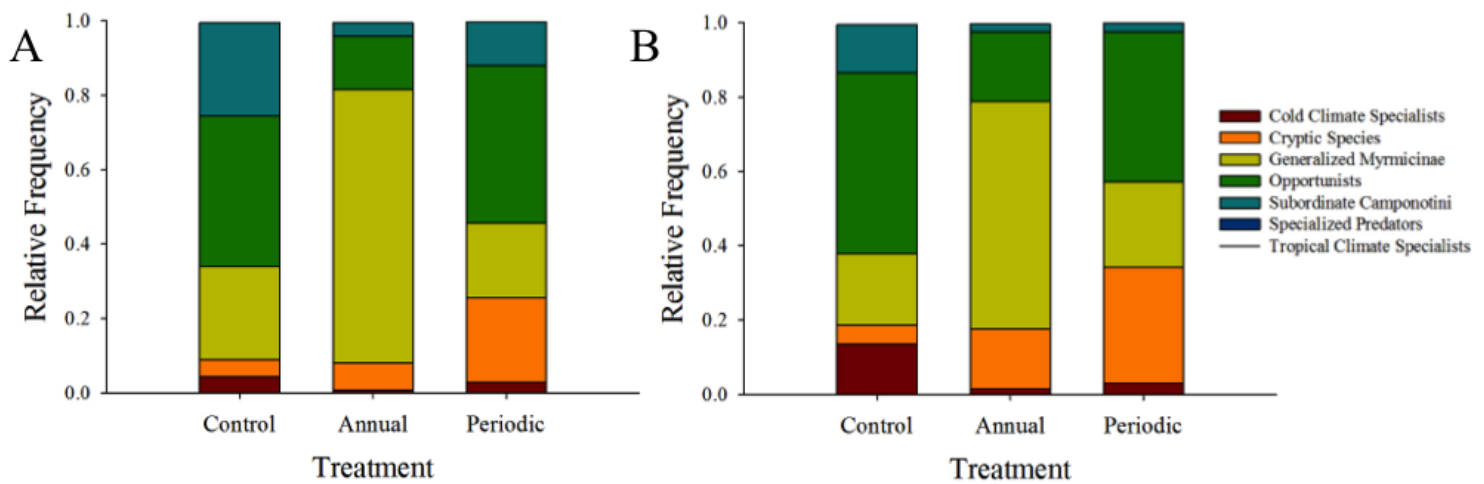

Fig. 2.4. Relative frequencies of functional groups in all three treatments for A) 2011 and B) 2012 .

Nesting behavior

Nesting behavior composition showed varying relative frequencies of each category across treatments and years resulting in some significant effects for individual 
nesting groups (Fig. 2.5). Soil nesting ants dominated over the other nesting types, irrespective of treatments, with the greatest number occurring in the annually burned plots (treatment effect $\mathrm{p}=0.0168)$ and in $2012(\mathrm{p}=0.0058)$. Cavity/litter nesting ants made up the second largest proportion of all nesting groups. Statistically, annual burns were significantly different from controls in 2011 and 2012. There were more litter/cavity nesters in annual burns in 2012 than 2011. All periodic burns were significantly different than controls with a year by treatment effect $(\mathrm{p}=0.0379)$. Results of the mixed model revealed no significant effects on arboreal nesters. Wood nesters were least abundant in annual burns with a significant difference from controls $(\mathrm{p}=0.0350)$.
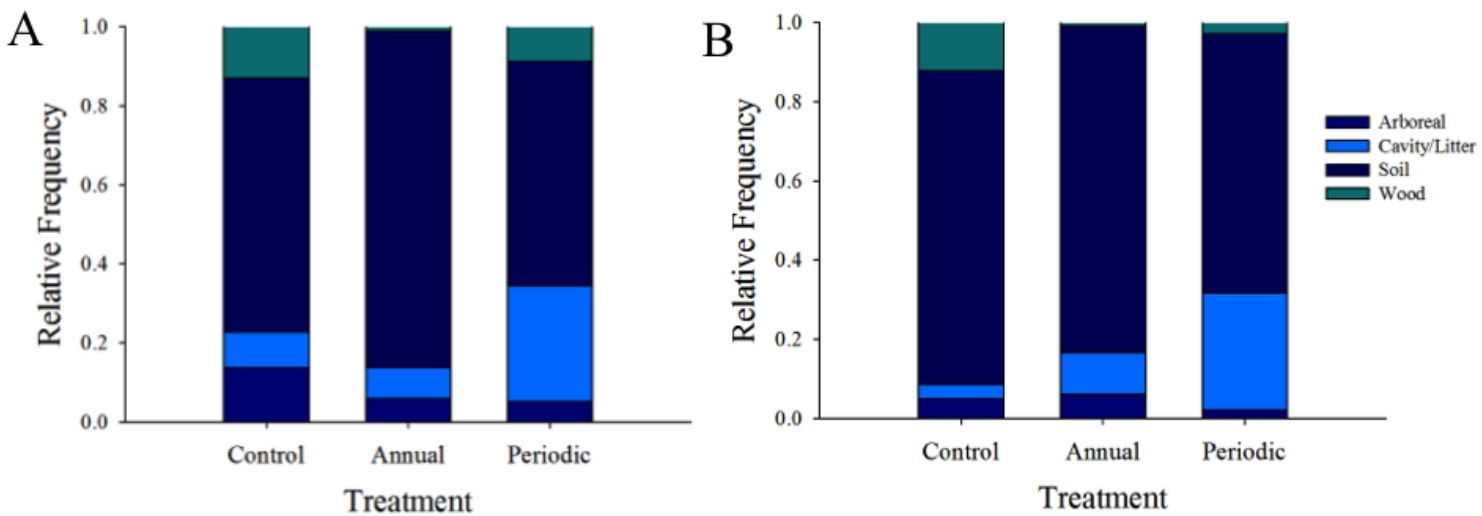

Fig. 2.5. Relative frequencies of nesting groups in all three treatments for A) 2011 B) and 2012.

Size class

Size classes of ants differed between treatments (Fig. 2.6). Small ants were most abundant in annual plots followed by periodic and control with significant differences between all treatments (treatment effect $\mathrm{p}=0.0005$ ). More small ants were also recorded in 2012 than 2011 ( $\mathrm{p}=0.0231$ ). Medium sized ants dominated in control plots, differing significantly from annual $(\mathrm{p}=0.0002)$ and periodically burned plots $(\mathrm{p}=0.0028)$. Periodic 
plots also differed from annual plots $(\mathrm{p}=0.0028)$ in the number of medium ants it supported. Abundances of large ants were not affected by any one variable.
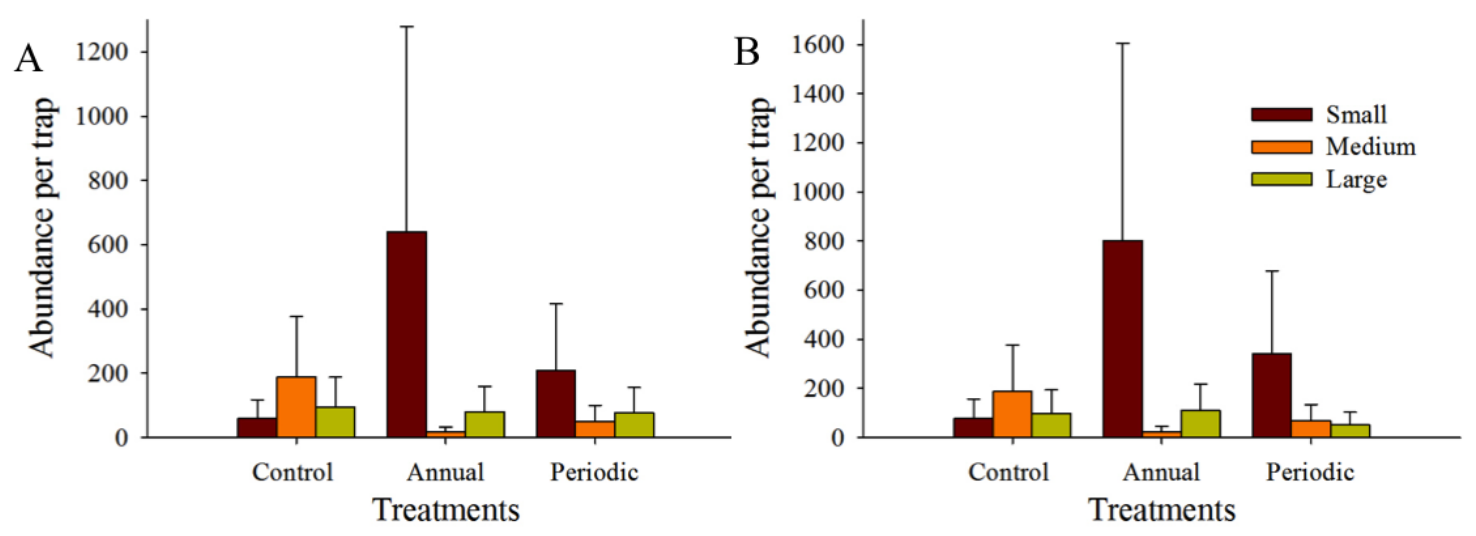

Fig. 2.6. Abundance per trap for small, medium and large size classes in all three treatments for A) 2011 and B) 2012. Error bars indicate mean +1 standard error. Species

Although most common species occurred in all treatments, their abundances per trap varied, often significantly. Annual burns contained the highest abundances per trap due to frequent occurrences of Monomorium minimum and Pheidole dentata (Fig. 2.7). The species $M$. minimum was found to be more abundant per trap in annual prescribed burn plots than both periodic $(\mathrm{p}=0.0214)$ and control plots $(\mathrm{p}=0.0004)$ and periodic plots contained more than control $(\mathrm{p}=0.0022)$. There was a year by treatment interaction for $P$. dentata $(\mathrm{p}=0.0089)$; annual plots contained more ants per trap than periodic and control plots in 2011 and 2012. Other ant species that occurred most frequently in annual burns include Pheidole tysoni (treatment effect $\mathrm{p}=0.0081$ ) and Trachymyrmex septentrionalis (treatment effect $\mathrm{p}=0.0612$ ) (Fig. 2.7). 
Mean abundance per trap Aphaenogaster group $\quad$ Mean abundance per trap Camponotus chromaiodes

Mean abundance per trap Temnothorax pergandei

A
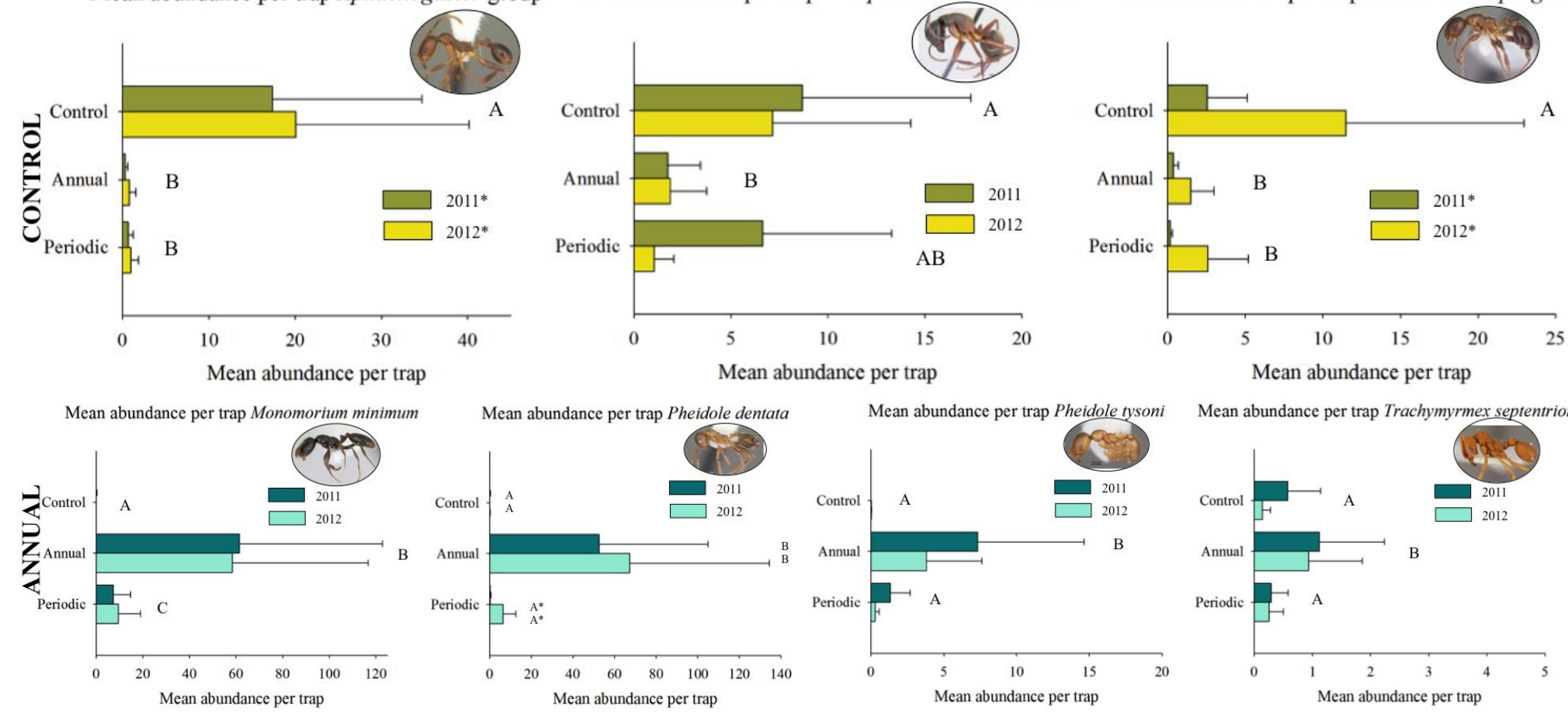

C
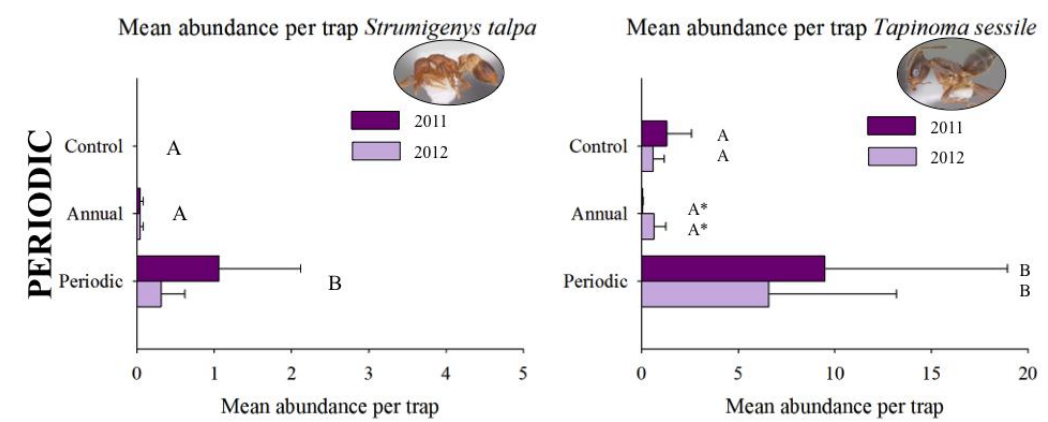

Fig. 2.7. Species mean abundances per trap for A) control plots including Aphaenogaster carolinensis $\mathrm{n}=19$, Camponotus chromaiodes, and Temnothorax pergandei, B) annually burned plots including Monomorium minimum, Pheidole dentata, Pheidole tysoni, and Trachymyrmex septentrionalis, and C) periodically burned plots including Strumygenys talpa and Tapinoma sessile. Error bars indicate mean +1 standard error. -Letters indicate significant differences between treatments. *indicates significant differences between years. 
A
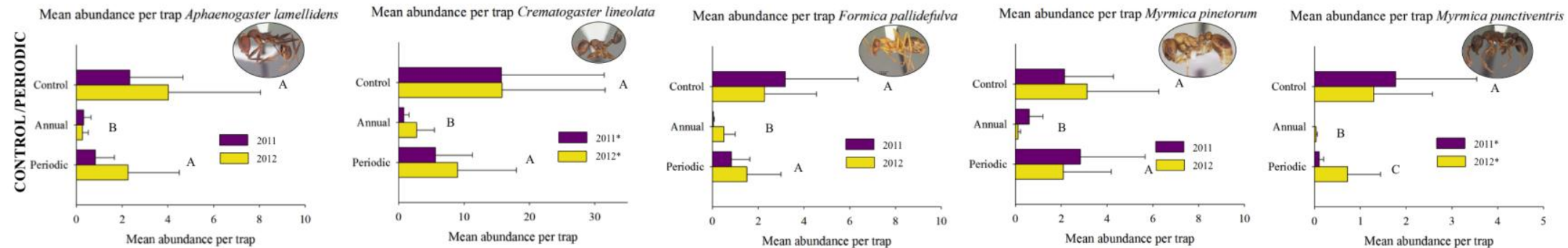

Mean abundance per trap Aphaenogaster treatae

Mean abundance per trap Nylanderia trageri

Mean abundance per trap Solenopsis spp.

$\mathrm{B}$
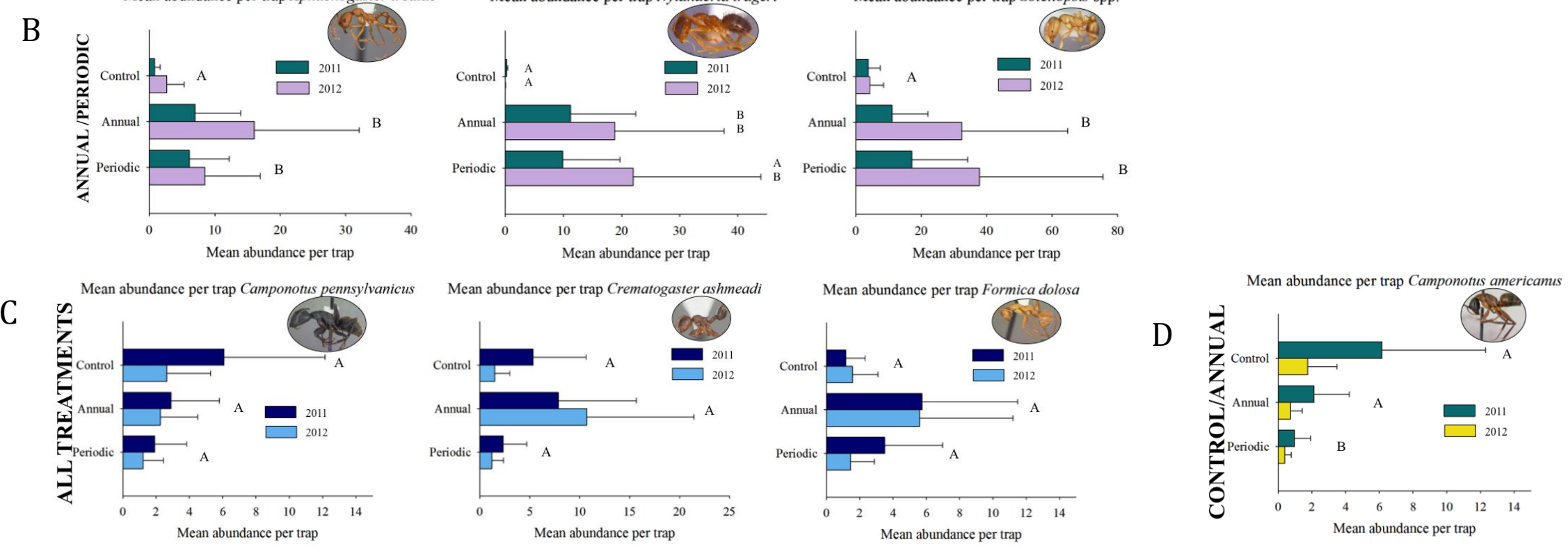

Fig. 2.8. Species mean abundances per trap for A) control/periodic plots including Aphaenogaster lamellidens,

Crematogaster lineolata, Formica pallidefulva, Myrmica pinetorum and Myrmica punctiventris, B) annually and periodically burned plots including Aphaenogaster treatae, Nylanderia trageri, and Solenopsis spp., C) all treatments including Camponotus pennsylvanicus, Crematogaster ashmeadi, and Formica dolosa and D) control and annually burned plots including Camponotus americana. Error bars indicate the mean +1 standard error.

-Letters indicate significant differences between treatments.

*indicates significant differences between years. 
Periodic burns favored abundance of Tapinoma sessile (treatment*year $\mathrm{p}=0.0338$ ) and Strumigenys talpa (treatment $\mathrm{p}=0.0097$ ) in both years (Fig. 2.7). Several species were common in both burned plots: Solenopsis spp., Aphaenogaster treatae, and Nylanderia trageri (Fig. 2.8). Abundances of Solenopsis spp. were almost 6 times higher in annual plots $(\mathrm{p}=0.0098)$ and 6.5 times higher in periodic plots $(\mathrm{p}=0.0060)$ than controls. The ant, A. treatae, also showed significantly higher abundance in annuals $(\mathrm{p}=0.0097)$ and periodic plots $(\mathrm{p}=0.0277)$ when compared with controls. There were year by treatment and block by treatment significant interactions for the $N$. trageri, one of the species found that is new to Missouri. Annual plots had significantly more than controls in 2011 $(\mathrm{p}=0.0103)$ and $2012(\mathrm{p}=0.0005)$ while periodic plots were significantly different from controls only in 2012 ( $\mathrm{p}=0.0004)$. Block F1 contained a greater number of Nylanderia trageri in 2012 than in 2011.

The following ant species were found more frequently in controls and periodic plots than annual plots: Aphaenogaster lamellidens (treatment effect, $\mathrm{p}=0.0126$ ), Crematogaster lineolata (treatment effect $\mathrm{p}=0.0144)$, Formica palliedefulva (treatment effect $\mathrm{p}=0.0153$ ), Myrmica pinetorum (treatment effect $\mathrm{p}=0.0164$ ) and Myrmica punctiventris (treatment effect $\mathrm{p}=0.0028$ ) dominated in periodic and controls (Fig. 2.8). The Aphaenogaster caroleninsis and A. n=19 group, Camponotus chromaoides and Temnothoroax pergandei were commonly found in control plots (Fig. 2.8). The Aphaenogaster group was 34 and 23 times more abundant in control plots than annual $(\mathrm{p}=0.0017)$ and periodic ( $\mathrm{p}=0.0025)$ plots, respectively (Fig. 2.8). The carpenter ant, $C$. chromaiodes was found to be significantly more abundant in control plots than annual plots $(\mathrm{p}=0.0345)$ but showed no difference between control and periodic plots. Annual 
and control plots shared abundances of one ant species, Camponotus americanus, when compared with periodic plots (treatment effect, $\mathrm{p}=0.0132$ ). Three of the more abundant ant species occurred similarly throughout all treatments with no significant effects: Camponotus pennsylvanicus, Crematogaster ashmeadi, and Formica dolosa (this species occurred more in periodically burned plots in 2011 than 2012, see below) (Fig. 2.8).

The year 2012 yielded more ants per trap for several species than 2011 including the Aphaenogaster carolinensis and $\mathrm{n}=19$ group ( $\mathrm{p}=0.0173)$, . fulva $(\mathrm{p}=0.0003), A$. treatae $(\mathrm{p}=0.0025)$, Crematogaster lineolata $(\mathrm{p}=0.0149)$, Myrmica punctiventris ( $\mathrm{p}=0.0388$ ), Nylanderia trageri for F1 (see above), Pheidole dentata for periodic plots only ( $\mathrm{p}=0.0019)$, Solenopsis $\mathrm{spp} .(\mathrm{p}=0.0137)$, Tapinoma sessile for annual plots only ( $\mathrm{p}=0.0077)$, and Temnothorax pergandei $(\mathrm{p}=0.0099)$. In 2011, only Camponotus americanus was more abundant $(\mathrm{p}=0.0132)$ and Formica dolosa in periodic plots $(\mathrm{p}=0.0149)$

Abundance based Morisita similarity indices revealed that all communities combined were about $16 \%$ similar (Fig. 2.9). Incidence-based Morisita similarity showed that control and annual plots were the most different with an index of 0.662 . Periodic burns were about $85 \%$ similar to both control and annual plots. When comparing years, the index showed very high similarity (Fig. 2.10). 

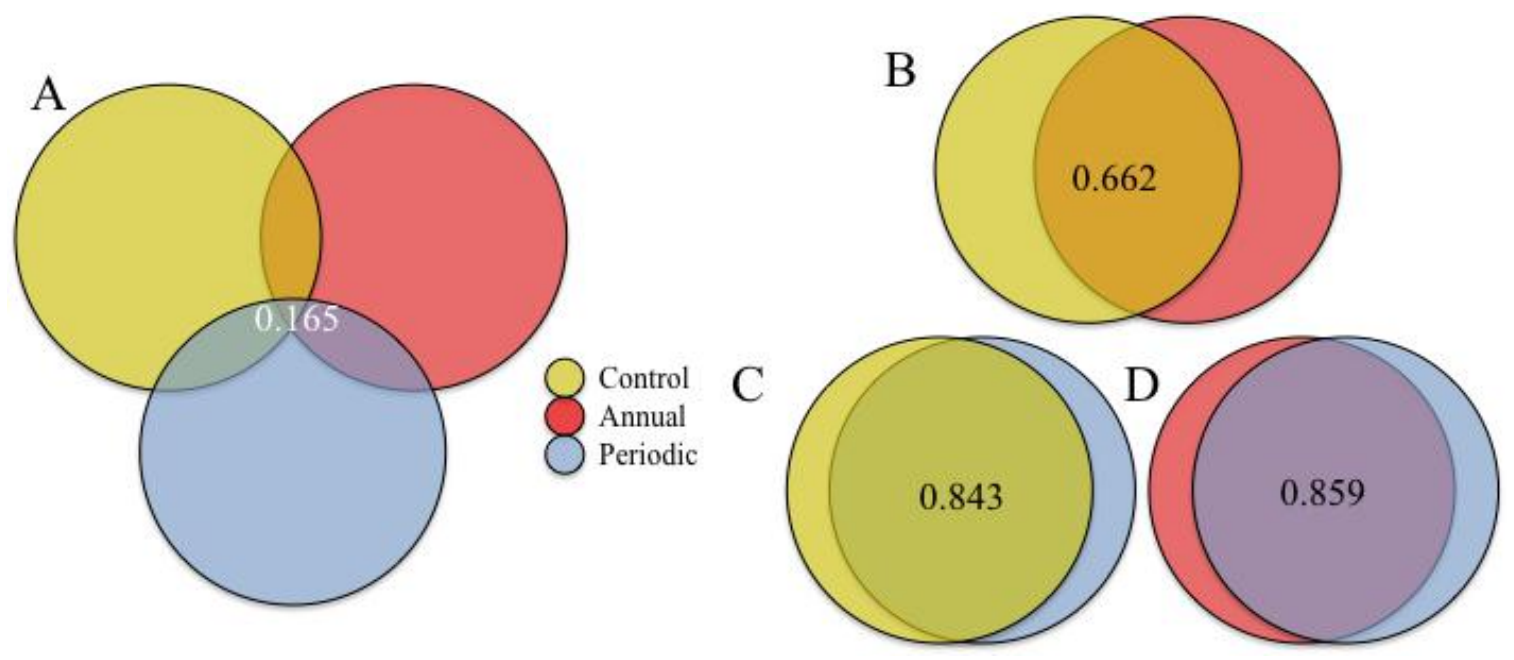

Fig. 2.9. A) Abundance-based Morisita similarity indices between all treatments combined. Pairwise incidence-based Morisita similarity indices between B) control and annual, C) control and periodica, and D) annual and periodic burns. The more the circles overlap the more similar the assemblages.

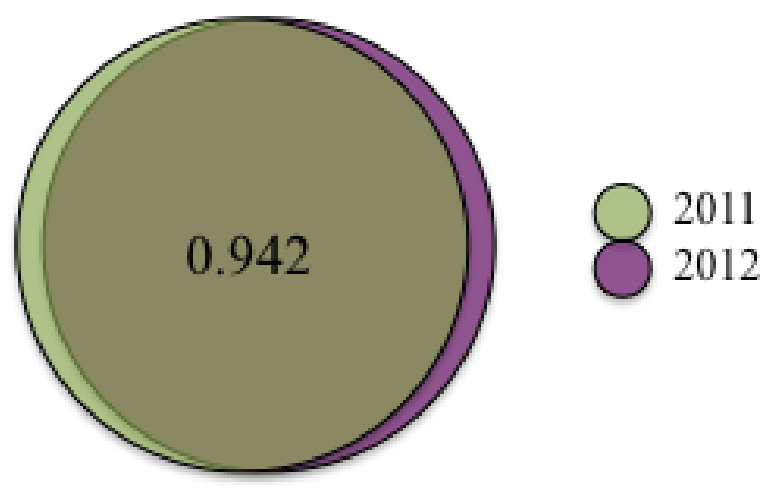

Fig. 2.10. Pairwise abundance-based Morisita similarity indices between 2011 and 2012 ant assemblages. The more the circles overlap the more similar the assemblages.

Multi-response permutation procedures showed that ant assemblages fall into distinct treatment groups (Table 2.6). The test statistic $\mathrm{T}=-12.449$ indicates a strong separation among groups $(\mathrm{p}<0.001)$. Chance corrected within group agreement was $\mathrm{A}=0.298$, meaning homogeneity was quite high within groups. Pairwise comparisons between treatment assemblages were all significant $(\mathrm{p}<0.0001)$ showing high separation 
between annual, periodic and control plots. Non-metric multidimensional scaling showed three distinct space polygons in two-dimensional space with a final stress of 10.85806

(Fig. 2.10). Stress is quite low, suggesting that data in two-dimensional space accurately portray data in actual space according to Clarke's rule of thumb (Clarke 1993).

Table 2.6. Results from the multiple response permutation procedure performed between treatments. The test statistic (T) is used to calculate between group or treatment separation (the more negative a value signifies a greater degree of separation). The agreement statistic (A) evaluates within group homogeneity (when $A=1$ communities are perfectly similar). P-values are generated using the Pearson type III distribution based on the test statistic.

\begin{tabular}{|c|c|c|c|}
\hline \multicolumn{2}{|c}{ Treatments statistic (T) } & $\begin{array}{c}\text { Agreement } \\
\text { Statistic (A) }\end{array}$ & p-value \\
\hline Control vs Annual & -9.760 & 0.341 & $\mathrm{p}<0.0001$ \\
\hline Control vs Periodic & -9.079 & 0.160 & $\mathrm{p}<0.0001$ \\
\hline Annual vs. Periodic & -7.877 & 0.211 & $\mathrm{p}<0.0001$ \\
\hline All Treatments & -12.449 & 0.298 & $\mathrm{p}<0.0001$ \\
\hline
\end{tabular}

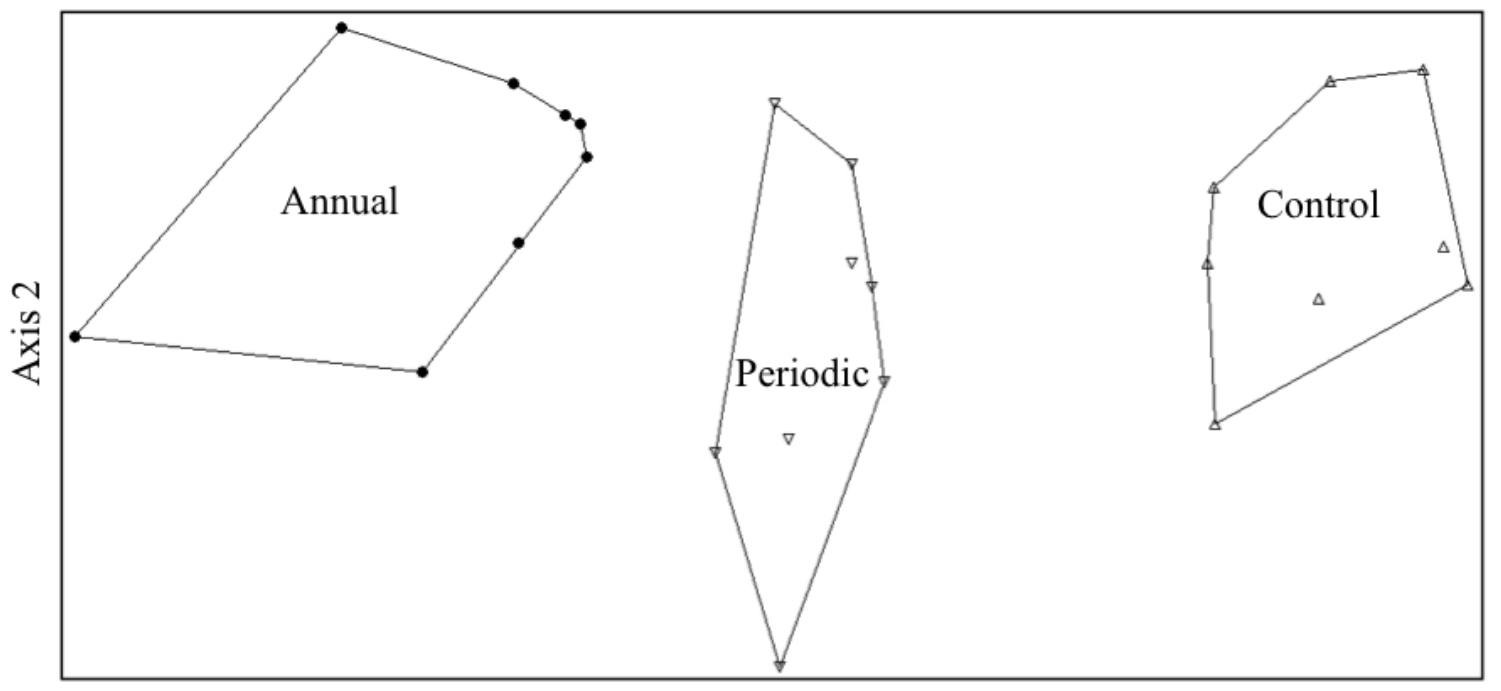

Axis 1

Fig. 2.11. Nonmetric multidimensional scaling ordination of treatments. 
Buffers

A total of 3,381 ants across 37 species, were collected in buffers. The buffers with two different, adjacent treatments (BAC, BAP, BCP) had higher observed and estimated (Chao2) richness than those buffers between two subplots of the same treatment (BAA, BCC, BPP) (Table 2.7). The highest richness value was associated with buffers between annual burns and control (Chao2= 44.34) and the lowest was in BAA (Chao2=20.25). The two least similar categories were BAA and BCP with a Sorensen index of 0.500 and 9 shared species while the most similar were BAP and BPP with 0.8636 and 19 shared species. Non-metric multidimensional scaling analysis resulted in 6 distinct groups in 3dimensional space with a stress of 4.71176 indicating an excellent representation of community assemblage of buffers in actual space following Clarke's rule of thumb (Clarke 1993) (Fig. 2.12).

Table. 2.7. Observed species richness and Chao2 incidence-based richness estimates are represented for each buffer category. Comparisons using incidence-based Sorenson Similarity Indices and number of shared species are also displayed.

\begin{tabular}{|c|c|c|c|c|c|c|}
\hline & BAA & BAC & BAP & BCC & BCP & BPP \\
\hline $\begin{array}{l}\text { Observed } \\
\text { Species } \\
\text { Richness }\end{array}$ & 14 & 32 & 24 & 16 & 22 & 20 \\
\hline Chao2 & 20.25 & 44.34 & 25.17 & 17.36 & 23.56 & 21.93 \\
\hline \multirow{7}{*}{$\begin{array}{l}\text { Multiple } \\
\text { Incidence- } \\
\text { based } \\
\text { Sorensen } \\
\text { Similarity }\end{array}$} & \multicolumn{2}{|c|}{$0.6087 / 14$} & \multicolumn{2}{|c|}{$0.6500 / 13$} & \multicolumn{2}{|c|}{$0.7619 / 16$} \\
\hline & \multicolumn{3}{|c|}{$0.7368 / 14$} & \multicolumn{3}{|c|}{$0.7222 / 13$} \\
\hline & \multicolumn{4}{|c|}{$0.5333 / 8$} & \multicolumn{2}{|c|}{-} \\
\hline & \multicolumn{5}{|c|}{$0.5000 / 9$} & - \\
\hline & \multicolumn{6}{|c|}{$0.7059 / 12$} \\
\hline & - & \multicolumn{2}{|c|}{$0.6471 / 22$} & \multicolumn{2}{|c|}{$0.6316 / 12$} & - \\
\hline & - & \multicolumn{3}{|c|}{$0.5833 / 14$} & \multicolumn{2}{|c|}{ - } \\
\hline
\end{tabular}




\begin{tabular}{|l|c|c|c|}
\hline \multirow{2}{*}{$\begin{array}{l}\text { Index / } \\
\text { No. of } \\
\text { shared } \\
\text { species }\end{array}$} & - & \multicolumn{3}{|c|}{$0.7037 / 19$} & - \\
\cline { 2 - 5 } & - & \multicolumn{3}{|c|}{$0.7308 / 19$} \\
\cline { 2 - 4 } & - & $0.7826 / 18$ & - \\
\hline & - & \multicolumn{3}{|c|}{$0.8636 / 19$} \\
\hline
\end{tabular}

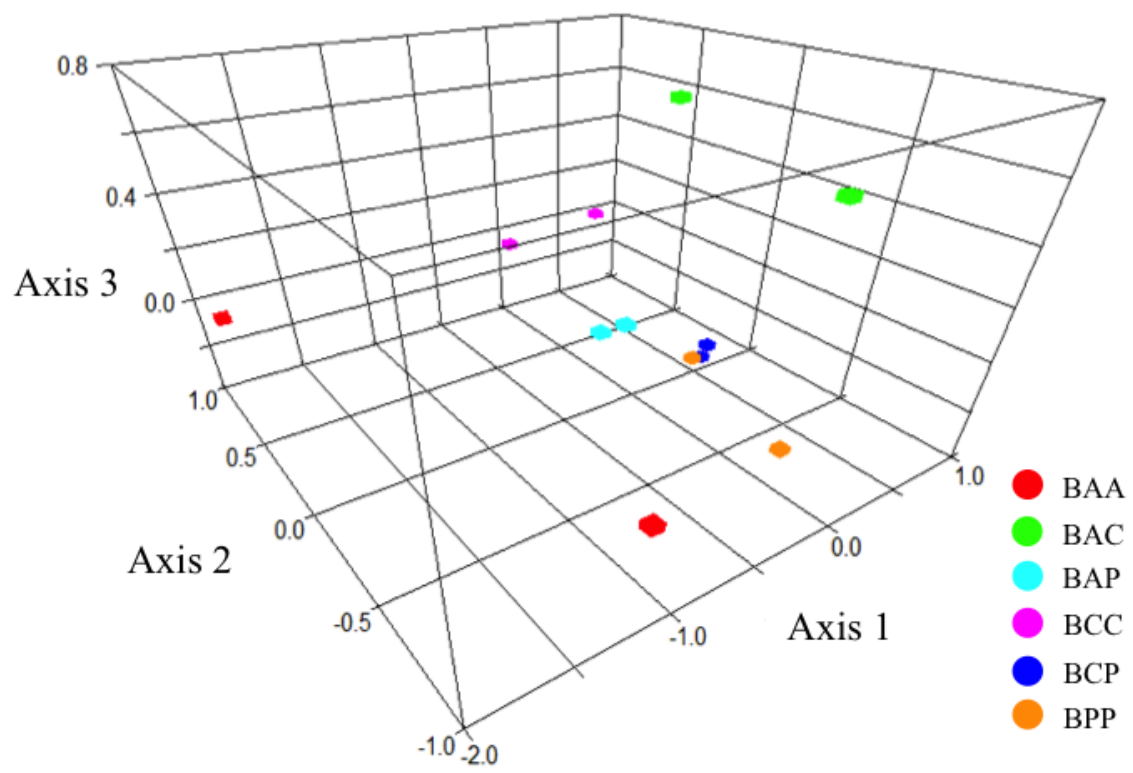

Fig. 2.12. Nonmetric multidimensional scaling ordination of buffer communities.

\section{Discussion}

\section{Diversity and abundance}

This study revealed that ant assemblages are not the same in areas subjected to different fire regimes (e.g. annual, periodic and no burning) based on data collected after over sixty years of prescribed burning. Other studies demonstrated that ant abundance is lowest in areas that were recently burned (e.g. <3 months) (Underwood and Quinn 2010, Matsuda et al. 2011, Verble 2012). Contrary to these findings, overall abundance of individual ants was highest in the annual burns along with periodic burns in F2 which 
burned in 2011. York (2000) found that frequent fires resulted in increases in ant abundance in a study in the coastal blackbutt forests in Australia, a site that had been burned repeatedly for over twenty years. Longevity of fire regimes may reflect a community of ants that can tolerate low intensity fires and the habitat conditions created by frequent fire. In addition, the simplified forest structure may allow for better "trapability" of individual ants (Andersen and Yen 1985, Majer 1997, Melbourne 1999, York 2000).

A total of 54 species were captured across treatment types and both blocks and years reflecting the heterogeneity of forest structure found in each treatment. The forest structure of annual and periodic plots differ from controls (Fig. 2.12). Controls have higher stocking of trees from a range of size classes. Very little light reaches the forest floor, which is densely covered in leaf litter but with sparse ground flora vegetation. The occasional woodland plant appears in control plots (Stephan 2010, unpublished data). Periodically burned plots have lower stocking levels with no midstory and a plethora of regenerating oak and hickory seedlings especially $>1$ year since fire. Common Ozark plants and more conservative woodland plants are found in these plots. Some leaf litter exists especially with increasing time since fire. Annual burns have woodland to savanna level stocking with no midstory and a blanket of forbs (Solidago spp., Symphiotrichum spp., Desmodium spp., Lespedeza spp., Helianthus hirsutus, Minuartia patula, etc.) and grasses (Andropogon gerardii, Schizochyrium scoparium, Dicanthelium spp.) in the understory with little to no tree regeneration or litter (Stephan 2010, unpublished data).

Observed species richness was affected by year and treatment. Annual plots had higher species richness in 2012 than control plots but the opposite was true in 2011. This 
and other year affects could be due to the 2012 drought; ant species are highly sensitive to environmental changes, which may result in temporal variation in assemblage dynamics. The total number of observed species was quite high compared to other studies. Verble (2013) worked in the Arkansas Ozarks in blocks that totaled more than 500 ha in size and sampled continuously throughout a year with a total observed species richness of 59 species. Another study in California sampled 1.2 ha sized blocks for 3 years with a total observed species richness of 16 (Underwood and Quinn 2010). This study examined two 1.25 ha blocks over 2 years and found 54 species. The Chao1 projected that all communities contained similar asymptotes in a species accumulation curve, revealing that, theoretically, no one treatment produces a more diverse assemblage than others. Rare species occurred more frequently in 2012. Rare species in 2012 found in burned plots may be a reflection of the harsher conditions in those plots with increased sunlight and fewer resources resulting in lower abundances of some species.

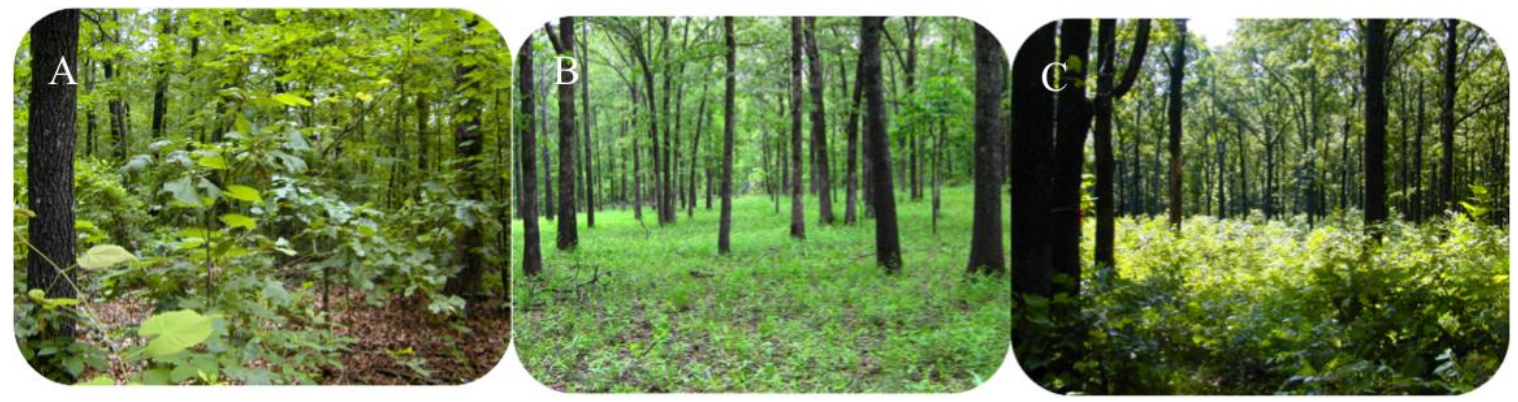

Fig. 2.13. Images of treatments at UFCA including A) control, B) annual, and C) periodic.

The number of rare species is reflected in the Shannon's diversity index, as this index is weighted towards species richness. This index log transforms relative abundance thus reducing the "presence" of abundant species. Because there were more rare species in periodic burns, the Shannon-Weiner Diversity Index was higher (greater diversity). 
Simpson's Index on the other hand squares relative abundances diminishing the presence of rarer species. This again, may explain why Simpson's diversity was lower (more diverse) in control plots with fewer dominant and rare species than the annual plots as this index is weighted toward dominance. Evenness indices showed that the annual burns were the least even owing to the large abundances of a few ant species in the annual burns.

\section{Functional groups}

The composition of functional groups differed across treatments. The functional groups found included Cold Climate Specialists (CCS), Cryptic Species (CR), Generalized Myrmicinae (GM), Opportunists (OP), Subordinate Camponotini (SC), Specialized Predators (SP), and Tropical Climate Specialists (TCS). Dominant Dolichoderines and hot climate specialists were not found at the UFCA. Not surprisingly, CCS were found to be significantly more abundant in controls. Controls have higher tree densities, a midstory, closed canopies and sufficient leaf litter to create a cooler microclimate for this group. Hoffman and Andersen (2003) reviewed the responses of ant functional groups to disturbance and noted that CR and SP were negatively affected by fire. CR ants at UFCA, however, increased after burning. Annual burns may have a low enough intensity because of there is little fuel (e.g. leaf litter, coarse woody debris) that these subterranean species go unaffected. Periodic burns burn with a higher intensity (Paulsell 1957, Scowcraft 1966) but perhaps the increased leaf litter favors increases in abundance of these CR ant species. Only one species, Polyergus longicornis, with two individuals was classified as a SP and therefore did not show any significant effects. There was a substantial increase in GM in annual burns a group that has been shown to 
respond variably to prescribed fire elsewhere (Izhaki et al. 2001, Stephens and Wagner 2006). OP are known to increase after prescribed fire because of their characteristic ability to pioneer disturbed habitats (Andersen 1995, Hoffman and Andersen 2003, Stephens and Wagner 2006, Moranz et al. 2013); but fire had no effect on OP in this study. Owing to the longevity of the fire regimes in place, it is possible that annually burned plots are at a steady successional state allowing for GM to move in and assert competitive dominance over OP. Predictably, SC were very common in control plots. Control plots contain more biomass e.g. woody debris, and snags to act as nesting sites for this group (Coovert 2005). TCS showed no significant effects in light of the few species that represented this group.

Nesting groups

Biomass is reduced after a fire altering habitat structure and reducing nesting resources, so, naturally, I expected that ant species' nesting strategies and behaviors would vary between treatments. Soil nesters were by far the most common, an anticipated consequence of using pitfall traps in the sampling protocol. It was unforeseen however that annual burns would host the highest abundance of soil nesters because of the potentially damaging direct effects of surface fires. On the other hand, annual burns are low intensity and can be patchy with low fuel loads and therefore may not harm soil nesters. Higher frequency of soil nesters in annual sites may result in increased soil aeration, turn over and drainage (Folgarait 1998). Cavity/litter nesting ants were common in annual burns in 2012 and periodic burns. It is possible that low intensity, patchy annual burns may leave refugia for litter and cavity dwelling ants. Arboreal nesters were not significantly different between years, treatments and block although controls have higher 
stem densities. Wood nesters were mostly species in the genus Camponotus, making it no surprise that they were found to be more numerous in control plots.

Size class

Variation exists between size classes among treatments. Most notably small ants dominated in annually burned plots. This is curious considering that smaller ants have a higher surface area to volume ratio and therefore may be more prone to desiccation, although it has been reported that certain smaller ants have a higher thermoregulatory tolerance (Verble 2012). Annual burns, in theory, would support a warmer and dryer microclimate than the other treatments due to increased insolation (sunlight), the lack of a midstory and minimal litter. On the contrary, medium ants numerically dominate (by way of sheer biomass) in control and periodic burns, reducing species richness of smaller subordinate ants (Parr and Gibb 2010). Frequent burning eliminates biomass that is utilized by medium bodied ants therefore releasing small ants from competition pressure. Stressed environments are favorable to some ants reducing competitive interactions. Large ants did not differ across treatment, year and block as expected in view of the high densities of SC in the control. The large ants Formica dolosa and Camponotus americanus did occur frequently in annual plots.

\section{Species}

Physical changes to the environment due to fire resulted in varying ant assemblages based on fire regime. Dominant ants in annual burns include Monomorium 
minimum, Pheidole dentata, Pheidole tysoni, and Trachymyrmex septentrionalis. The former three are all GM that nest in the soil. They are all known to be quite common and are often found in parks and yards in urbanized areas. So, although they are not classified as OP, they establish in stressed habitats (James Trager, personal communication). Trachymyrmex septentrionalis is a TCS and fungus grower related to the leaf-cutter ants. It is commonly found in oak woodlands (James Trager, personal communication). All of these ants prefer sandy, well-drained soils and open habitats, characteristic of the annually burned forests.

Periodic burns uniquely host only two species frequently: Tapinoma sessile and Strumigenys talpa. Nest migration is common in Tapinoma sessile, a potential reason for its overwhelming presence in periodic burns. Frequent disturbances in like periodic burns may induce this migration. These ants also nest under dead wood and periodic plots burn with greater intensity than annual burns resulting in higher stem mortality (Huddle and Pallardy 1996). The cryptic ant Strumigenys talpa is also consistently occurs in periodic burn plots although in much lower densities. This species feeds on collembolans or springtails, primitive insect detritivores, in the litter and topsoil and could potentially alter rates of decomposition in great abundances.

Species found in both annuals and controls include Nylanderia trageri, Solenopsis spp., and Aphaenogaster treatae. Nylanderia trageri is a new record for the state of Missouri and it exhibits opportunistic and generalist tendencies. High frequencies of $A$. treatae may be partially explained by increased grasses and sedges in these areas; these ants nest at the base of graminoid clumps and scavenge for dead insects and are active seed dispersers. The high occurrence of Solenopsis spp. in burned areas is mostly due to 
their nesting and foraging habits. They are frequently associated with Pheidole spp., Aphaenogaster and Myrmica from which they steal food items. Periodic burns share higher abundances of Aphaenogaster lamellidens, Crematogaster lineolata, Formica pallidefulva, Myrmica pinetorum and Myrmica punctiventris. The number of shared abundant species demonstrates that periodically burned plots embody physical characteristics of annually burned and control plots.

Control plots had three associated common ants: Aphaenogaster caroleninsis and n=19 group, Camponotus chromaiodes, and Temnothorax pergandei. The Aphaenogaster are well-known seed dispersers of plant species found throughout the Ozarks making this species ecologically important. Regardless of their classification as SC, this ant dominates numerically and through biomass. It is in rotting wood nesting ant low on the bole of dead and living trees. Increases could affect weak trees like the declining red oak group in the region. The dominance of these ant species in control plots indicates that this ant group may be increasing in abundance throughout the Ozarks in response to fire suppression. It will be important to examine ants in other restoration sites to confirm this trend.

Buffers

Buffers display characteristics of the two treatments adjacent to them and the ant species composition and assemblage similarity reflected this as well. These buffers demonstrate the importance of heterogeneous habitat characteristics in order to maintain species high species diversity. First of all, the transition between treatments occurs in a 10.1 meter strip along each plot yet, irrespective of the small size of this buffer, ant 
communities clearly contain species that are dominant in adjacent treatments. Buffers between two plots of the same treatment have lower species richness than those between two different treatments. This further demonstrates that habitat alteration due to fire results in distinct ant communities.

Ant species state records

Three ant species were found that represent new state records: Nylanderia trageri, Polyergus longicornis, and Strumigenys louisianae. Nylanderia trageri is a species that is relatively new to science and was previously considered a yellow color morph of N.parvula (Kallal and La Polla 2012). Therefore it is likely this species has been collected in the state before and misidentified as it has been found in similar habitats in the central United States. The obligate slave-making ant, Polyergus longicornis is closely associated with Formica dolosa (MacGown 2013) and found in Mississippi, Georgia, Florida, South Carolina and North Carolina. Obligate slave-making ants are dependent on host colonies to forage, raise their broods, and take out the waste, etc. while workers of this group raid host colonies. Stumigenys louisianae, a cryptic species, is a predator of collembolans or springtails, tiny detritivorous primitive insects that live in the litter and the soil. These ants range from Central America to the tropics and subtropics of the southeastern United States. This species was also recently found in Illinois, another state record (James Trager, personal communication). Range expansion northward of this species and Polyergus longicornis may be a response to climate conditions. More investigation is needed to determine climatic tolerances of these species and how climate and fire interact. 


\section{Conclusions}

This study revealed strikingly different ant assemblages under annual and periodic fire regimes and no fire regime. In a total of $2.5 \mathrm{ha}$ and 4 weeks of sampling time over two years 54 species were identified with 3 new state records. When compared to studies over a larger area, this number is quite high (Izhaki et al. 2003, Stephens and Wagner 2006, Underwood and Quinn 2010, Verble 2013). The heterogeneity in the habitat structure of the three treatments may be the mechanism for this richness. Land managers aiming to restore natural communities in the region should take into account the importance of habitat heterogeneity in maintaining high ant diversity and function of restored ecosystems; in addition, they should note that responses of ants to disturbances correlate to those of other arthropods (Andersen et al. 2004, Andersen 2010) and assemblage patterns of other animal and plant groups (Majer et al. 2007). Ant abundance increased in areas of annual fire in block F1 where there were deeper soils. This may indicate that they are not as sensitive to the direct heat of fire itself as they are to fire-induced changes in their environment (Farji-Brener et al. 2002, Hoffman and Andersen 2003), identifying individual nest sites and monitoring may reveal sensitivity to fire.

Ant species composition also differs with repeated fires over the course of $60+$ years. Different species dominate when exposed to annual fire versus controls, however, periodic burns have ants that are dominant in annuals and controls. These species specific changes are reflected in functional groups as well. Small, soil nesting GM dominate in annuals, medium sized, wood-nesting CCS and SC in controls and small and medium litter-nesting $\mathrm{CR}$ in periodic burns. These simplifications may make ants easier to monitor for managers. Prescribe burning treatments that have been implemented for over 
sixty years have clear and distinguished effects on ant assemblages at the University

Forest Conservation Area. This study shows that heterogeneous application of fire results in a biologically and functionally diverse ant community. 


\section{Literature cited}

Abrams, M. D. 1992. Fire and the development of oak forests. BioScience 42:346-353.

Andersen, A. N. 1991. Responses of ground-foraging ant communities to three experimental fire regimes in a savanna forest of tropical Australia. Biotropica 23:575-585.

Andersen, A. N. 1995. A classification of Australian ant communities, based on functional group which parallel plant life-forms in relation to stress and disturbance. Journal of Biogeography 22:15-29.

Andersen, A. N. 1997. Functional groups and patterns of organization in North American ant communities: a comparison with Australia. Journal of Biogeography 24:433460.

Andersen, A. N. 2010. Functional groups in ant community ecology Pages 142-144 in L. Lach, C. L. Parr, and K. L. Abbott, editors. Ant Ecology. Oxford University Press, Oxford, England.

Andersen, A. N., A. Fisher, B. D. Hoffman, J. L. Read, and R. Richards. 2004. Use of terrestrial inverstebrates for biodiversity monitoring in Australian rangelands, with particular reference to ants. Austral Ecology 29:87-92.

Andersen, A. N., B. D. Hoffman, W. J. Muller, and A. D. Griffiths. 2002. Using ants as bioindicators in land management: simplifying assessment of ant community responses. Journal of Applied Ecology 39:8-17.

Andersen, A. N. and A. L. Yen. 1985. Immediate effects f fire on ants in the sei-arid mallee region of north-western Victoria. . Australian Journal of Ecology 10:2530 .

Bell, A. L. 2007. The effects of fire management on avian species in Missouri Ozark glade-woodland habitats. M.S. thesis, University of Michigan. 96p.

Bestelmeyer, B. T., D. Agosti, L. E. Alonso, C. R. F. Brandao, W. L. Brown, J. H. C. Delabie, and R. Silvestre. 2000. Field techniques for the study of ground-dwelling ants. Pages 122-144 in D. Agosti, J. D. Majer, L. E. Alonso, and T. R. Schultz, editors. Ants: standard methods for measuring and monitoring biodiversity. Smithsonian Institution Press, Washington, D.C.

Blake, J. G. 2005. Effects of prescribed burning on distribution and abundance of birds in a closed-canopy oak-dominated forest, Missouri, USA. Biological Conservation 121:519-531. 
Brisson, J. A., J. L. Strasburg, and A. R. Templeton. 2003. Impact of fire management on the ecology of collared lizard (Crotaphytus collaris) populations living on the Ozark Plateau. Animal Conservation 6:247-254.

Chao, A. 1984. Nonparametric estimation of the number of classes ina population. Scandanavian Journal of Statistics 11:265-270.

Chao, A. and T. J. Shen. 2010. Program SPADE (Species Prediction and Diversity Estimation). Program and User's Guide. http://chao.stat.nthu.edu.tw. Last accessed October 12th, 2013.

Chao, A., T. J. Shen, and W. H. Hwang. 2006. Application of Laplace's boundary-mode approximations to estimate species and shared species richness. Australian and New Zealand Journal of Statistics 48:117-128.

Chao, A., L. Jost, S. C. Chiang, Y. H. Jiang, and R. Chazdon. 2008. A two-stage probabalistic approach to multiple-community similarity indices. Biometrics 64:1178-1186.

Clarke, K. R. 1993. Non-parametric multivariate analyses of changes in community structure. Australian Journal of Ecology 18:117-143.

Conover, W. J. and R. L. Iman. 1981. Rank transformations as a bridge between parametric and nonparametric statistics. The American Statistician 35:124-129.

Coovert, G. A. 2005. The Ants of Ohio (Hymenoptera: Formicidae). Ohio Biological Surver, Inc., Columbus, OH.

Creighton, W. S. 1950. Bulletin of the Museum of Comparative Zoology: The Ants of North America. Harvard College, Cambridge, MA.

Dey, D. C. and G. W. Hartman. 2005. Returning fire to Ozark Highland forest ecosystems: effects on advance regeneration. Forest Ecology and Management 217:37-53.

Farji-Brener, A. G., J. C. Corley, and J. Bettinelli. 2002. The effects of fire on ant communities in north-western Patagonia: the importance of habitat structure and regional context. Diversity and Districutions 8:235-243.

Folgarait, P. J. 1998. Ant diversity and its relationship to ecosystem functioning: a review. Biodiversity and Conservation 7:1221-1244.

Gotelli, N. J. and A. M. Ellison. 2013. A Primer of Ecological Statistics. Sinauer Associates, Inc., Sunderland, MA. 
Gotelli, N. J., A. M. Ellison, R. R. Dunn, and N. J. Sanders. 2011. Counting ants (Hymenoptera: Formicidae): biodiversity sampling and statistical analysis for myrmecologists. Myrmecological News 15:13-19.

Grime, J. P. 1979. Plant Strategies, Vegetation Processes, and Ecosystem Properties. John Wiley, Chichester, UK.

Guyette, R. P. and B. E. Cutter. 1997. Fire history, population, and calcium cycling in the Current River Watershed.in Proceedings, 11th Central Hardwood Conference; Columbia, MO. Gen. Tech. Rep. NC-188. St. Paul, MN: Department of Agriculture, Forest Service, North Central Forest Experiment Station: 354-372.

Guyette, R. P. and D. C. Dey. 2000. Humans, topography, and wildland fire: the ingredients for long-term patterns in ecosystems. Pages 28-35 in Workshop on Fire, People and the Central Hardwoods Landscape. USDA Forest Service, Richmond, KY.

Guyette, R. P., R. M. Muzika, and D. C. Dey. 2002. Dynamics of an anthropogenic fire regime. Ecosystems 5:472-486.

High Plains Regional Climate Center. 2013. Wappapello Dam, MO. http://www.hprcc.unl.edu/cgi-bin/cli_perl_lib/cliMAIN.pl?mo8700. Last accessed October 12, 2013.

Hoffman, B. D. and A. N. Andersen. 2003. Responses of ants to disturbance in Australia, with particular reference to functional groups. Austral Ecology 28:444-464.

Huddle, J. A. and S. G. Pallardy. 1996. Effects of long-term annual and periodic burning on tree survival and growth in a Missouri Ozark oak-hickory forest. Forest Ecology and Management 82:1-9.

Huddle, J. A. and S. G. Pallardy. 1999. Effect of fire on survival and growth of Acer rubrum and Quercus seedlings. Forest Ecology and Management 118:49-56.

Izhaki, I., D. J. Levey, and W. R. Silva. 2001. Effects of prescribed fire on an ant community in Florida pine savanna. Ecological Entomology 28:439-448.

Jurney, D. H. 2012. Anthropology of fire in the Ozark Highland region.in 4th Fire in Eastern Oak Forests Conference, Springfield, MO.

Kallal, R. J. and J. S. LaPolla. 2012. Monograph of Nylanderia (Hymenoptera: Formicidae) of the World, Part II: Nylanderia in the Nearctic Zootaxa 3508:1-64.

Kaspari, M. and J. D. Majer. 2000. Using ants to monitor environmental change. Pages 89-98 in D. Agosti, J. D. Majer, L. E. Alonso, and T. Shultz, editors. Ants: 
standard methods for measuring and monitoring biodiversity. Smithsonian Institution Press, Washington, DC.

King, J. R., A. N. Andersen, and A. D. Cutter. 1998. Ants as bioindicators of habitat disturbance: validation of the functional group model for Australia's humid tropics. Biodiversity and Conservation 7:1627-1638.

Kinkead, C. 2013. Thinning and burning in oak woodlands. Master's thesis. University of Missouri, Columbia, MO. 125p.

Lach, L., C. L. Parr, and K. L. Abbott. 2010. Preface. Page 402 in L. Lach, C. L. Parr, and K. L. Abbott, editors. Ant Ecology. Oxford University Press, Oxford, England.

Ladd, D. 1991. Reexaminaation of the role of fire in Missouri oak woodlands. Pages 6780 in Oak Woods Management Workshop, Eastern Illinois University, Charleston, IL.

MacGown, J. A. 2013. Ants (Formicidae) of the southeastern United States. http://mississippientomologicalmuseum.org.msstate.edu/Researchtaxapages/Form icidaehome.html. Last accessed October 12, 2013.

Majer, J. D. 1997. The use of pitfall traps for sampling ants--a critique. Memoirs of the Museum of Victoria 56:323-329.

Majer, J. D., G. Orabi, and L. Bisevac. 2007. Ants (Hymenoptera: Formicidae) pass the bioindicator scorecard. Myrmecological News 10:69-76.

Matsuda, T., G. Turschak, C. Brehme, C. Rochester, M. Mitrovich, and R. Fisher. 2011. Effects of large-scale wildfires on ground foragin ants (Hymenoptera:

Formicidae) in Southern California Environmental Entomology 40:204-216.

McCarty, K. 1998. Landscape-scale restoration in Missouri savannas and woodlands. Restoration and Management Notes 161:22-32.

McCune, B. and M. J. Mefford. 1999. PC-ORD: multivariate analysis of ecological data version 6.0. MjM Software Design, Gleneden Beach, OR.

Melbourne, B. A. 1999. Bias in the effect of habitat structure on pitfall traps: an experimental evaluation. Australian Journal of Ecology 24:228-239.

Mielke, P. W. and K. J. Berry. 2001. Permutation Methods: A Distance Function Approach. Springer-Verlag, New York, NY.

Missouri Department of Conservation. 2012. University Forest Conservation Area. Available online at http://mdc4.mdc.mo.gov/applications/moatlas/Area 
SummaryPage.aspx?txtAreaID=8850. Last accessed November 4th, 2013.

Moranz, R. A., D. M. Debinski, L. Winkler, J. Trager, D. A. McGranahan, D. M. Engle, and J. R. Miller. 2013. Effects of grassland management practices on ant functional groups in central North America. Journal of Insect Conservation 17:699-713.

Nelson, P. W. 2005. The Terrestrial Natural Communities of Missouri. Missouri Natural Areas Committee, Jefferson City, MO.

Nigh, T. A. 1992. The forests prior to European settlement. Pages 6-13 in A. R. P. Journet and H. G. Spratt, editors. Towards a vision for Missouri's public forests. Southeast Missouri State Unviversity, Cape Girardeau, MO.

Nigh, T. A. and W. A. Schroeder. 2002. Atlas of Missouri Ecoregions. The Missouri Department of Conservation, Jefferson City, Mo.

Nowacki, G. J. and M. D. Abrams. 2008. The demise of fire and "mesophication" of forests in the eastern United States. BioScience 58:123-138.

Pallardy, S. G., T. A. Nigh, and H. G. Garrett. 1988. Changes in forest composition in Central Missouri: 1968-1982. American Midland Naturalist 120:380-390.

Parr, C. L. and H. Gibb. 2010. Competition and the role of dominant ants. Pages 77-96 in L. Lach, C. L. Parr, and K. L. Abbott, editors. Ant Ecology. Oxford University Press, Oxford, UK.

Paulsell, L. K. 1957. Effects of burning on Ozark hardwood timberlands. University of Missouri College of Agriculture, Agricultural Experiment Bulletin 640.

SAS Institute Inc. 2012. What's New in SAS ® 9.3. Cary, NC: SAS Institute Inc., 2012.

Scowcraft, P. G. 1966. The effects of fire on the hardwood forests of the Missouri Ozarks. M.S. Thesis, University of Missouri.

Shen, T. J., A. Chao, and J. F. Lin. 2003. Predicting the number of new species in a further taxonomic sampling. Ecology 84:798-804.

Snelling, G. C. and R. R. Snelling. 2007. New synonym, new species, new keys to Neivamyrmex army ants of the United States. Pages 459-550 in R. R. Snelling, B. L. Fisher, and P. S. Ward, editors. Advances in ant systematics (Hymenoptera: Formicidae): homage to E.O. Wilson--50 years of contributions. Memoirs of the American Entomological Institute.

Stephan, K. 2010. Plant data from University Forest Conservation Area burn plots. Unpublished raw data. 
Stephens, S. S. and M. R. Wagner. 2006. Using ground foraging ant (Hymenoptera: Formicidae) functional groups as bioindicators of forest health in northern Arizona ponderosa pine forests. Community and Ecosystem Ecology 35:937-949.

Taft, J. B. 2009. Effects of overstory stand density and fire on ground layer and veetation in oak woodland and savanna habitats. Pages 21-39 in 3rd Fire in Eastern oak forests conference; Carbondale, IL. Gen. Tech. Rep. NRS-P-46. U.S. Department of Agriculture, Forest Service, Northern Research Station.

Templeton, A. R., R. J. Robertson, J. A. Brisson, and J. L. Strasburg. 2001. Disrupting evolutionalry processes: the effect of habitat fragmentation on collared lizards in the Misouri Ozarks. Proceedings of the National Academy of Sceinces of the United States of America 98:5426-5432.

Trager, J. 2013. Missouri Ants. http://www.antweb.org, Last accessed September 21, 2013.

Trager, J. C., J. A. MacGown, and M. D. Trager. 2007. Revision of Nearctic endemic Formica pallidefulva group, pp. 610-636. In Snelling, R.R., B.L. Fisher, and P.S. Ward (eds). Advances in ant systematics (Hymenoptera: Formicidae): homage to E.O. Wilson - 50 years of contributions. Memoirs of the American Entomological Institute, 80 .

Umphrey, G. J. 1996. Morphometric discrimination among sibling species in the fulvarudis-texana complex of the ant genus Aphaenogaster (Hymenoptera: Formicidae). Canadian Journal of Zoology 74:528-559.

Underwood, E. C. and B. L. Fisher. 2006. The role of ants in conservation monitoring: If, when, and how. Biological Conservation 132:166-182.

Underwood, E. C. and J. F. Quinn. 2010. Response of ants and spiders to prescribed fire in oak woodlands of California. Journal of Insect Conservation 14:359-366.

Unstad, K. 2012. Predictors of insect diversity and abundance in a fragmented tallgrass prairie ecosystem. Master's thesis. University of Nebraska, Lincoln, NE.

Verble, R. M. 2012. Effects of prescribed fire on Ozark ant ecology. Dissertation. University of Arkansas-Little Rock.

Wilson, E. O. and B. Hölldobler. 2005. The rise of the ants: a phylogenetic and ecological explanation. Proceedings of the National Academy of Sceinces of the United States of America 102:7411-7414.

York, A. 2000. Long-term effects of frequent low-intensity burning on ant communities in coastal blackcutt forests of southeastern Australia Austral Ecology 25:83-98. 
Zimmerman, G. M., H. Goetz, and P. W. Mielke. 1985. Use of an improved statistical method for group comparisons to study effects of prairie fire. Ecology 66:606611. 


\section{CHAPTER 3. RESPONSES OF GROUND-FORAGING ANT ASSEMBLAGES TO PRESCRIBED FIRE AND TOPOGRAPHIC POSITION IN AN OAK WOODLAND RESTORATION STUDY SITE}

\section{Introduction}

Oak woodland restoration is increasingly common in Missouri and other areas of the Central Hardwood Region (McCarty 1998, Lowenstein et al. 2002, Dey and Hartman 2005, Nelson 2005, Phillips et al. 2007, Taft 2009, Arthur et al. 2012). Woodland communities are defined by widely spaced trees, the lack of a mid-story and a rich layer of understory of forbs, sedges and grasses (McCarty 1998, Nelson 2005, Taft 2009). Fire is one of the main drivers of woodland community structure. It removes biomass such as leaf litter, invasive species, and fire-intolerant tree species, thereby releasing resources and physical space in the stand that allows light to penetrate the canopy and stimulate herbaceous plant growth (Nelson 2005).

Oak woodlands were once much more common throughout the Central Hardwoods Region of the continental United States, especially in prairie and savanna ecotones (Ladd 1991, Nigh 1992, McCarty 1998, Nelson 2005, Taft 2009). Fire scars revealed through tree ring analyses, indicate that fires occurred infrequently before 1850 , but as often as every 2.8 years after 1850 (Guyette and Cutter 1991, Cutter and Guyette 1994, Guyette and Cutter 1997, Guyette et al. 2002, Guyette and Spetich 2003, Guyette et al. 2006). Both natural ignitions (e.g. lightning) and anthropogenic fires contributed to the central hardwood fire regime, but each differed in importance during certain time periods. (Ladd 1991, Nigh 1992, Guyette and Dey 2000, Guyette et al. 2002). Native Americans frequently used fire to clear woods for better visibility of hunters and approaching 
enemies (Ladd 1991). Ignitions increased with increasing population density in particular after Euro-American settlement circa 1850 when Euro-Americans settled the land bringing with them a culture of frequent forest burning (Guyette and Cutter 1991, Guyette et al. 2002). In order to preserve fuel and forest resources, in addition to political responses to catastrophic wild fires, fire interval became great (to over decades) during the period of fire suppression (Strausberg and Hough 1997, Fralish 2004, Stephens and Ruth 2005). Fire suppression has altered forests in the Central Hardwood region with resulting increases in stem densities and basal areas of fire-intolerant species (Pallardy et al. 1988, Guyette et al. 2007, McMurry and Muzika 2007).

Currently, efforts are underway to restore fire to the landscape in the Central Hardwood region and in Missouri. Restoring and monitoring abiotic and biotic environmental changes after a fire is a key step in restoration (Spellerberg 2005), particularly when the management goals include increasing biotic diversity. Woody and herbaceous vegetation sampling is often part of the protocol in woodland and savanna restoration (Hartman and Heumann 2003, Dey and Hartman 2005, McMurry et al. 2007, Kinkead 2013). Responses of mammals, birds, and herpetofauna to fire have also been recorded (Templeton et al. 2001, Brisson et al. 2003, Blake 2005, Keyser and Ford 2006, Bell 2007). Insects, however -the most diverse group of animals on Earth (Price 2002) are severely underrepresented in restoration projects in Missouri. They contribute to myriad ecosystem processes and serve as food resources for wildlife (Price et al. 2011, Scholwater 2011).

In this study, I sought to evaluate the effects of prescribed fire on ant assemblages. Notably, ants are known to be quite sensitive to disturbance in general 
(Underwood and Fisher 2006), and specifically fire. Fire combusts potential nesting habitat for ants, e.g. acorns, plants, twigs, litter and coarse woody debris (Houdeshell et al. 2011), alters soil nutrient, moisture and temperature, and limits prey availability (Coleman and Rieske 2006), thereby potentially changes species' presence and abundance. Colonies are mostly sedentary, occupying nests from several months to many years (Hölldobler and Wilson 1990); like plants, their presence can be temporally monitored. Ants will abandon their nests however if competition, stress or disturbance causes them to do so (Parr and Gibb 2010, Philpott et al. 2010); moreover, disturbance may result in direct mortality (Andersen 1995, Hoffman and Andersen 2003). In this way, they may react to these factors rapidly, and therefore provide insight into changes in microclimate that may go unnoticed with plants.

Outside of Missouri, ants have been used in monitoring programs of restoration sites, particularly in Australia (Andersen and Yen 1985, Andersen 1991, 1997, York 2000, Izhaki et al. 2001, Andersen et al. 2002, Farji-Brener et al. 2002, Hoffman and Andersen 2003, Andersen et al. 2004, Ottonetti et al. 2006, Kittelson et al. 2008, Fagan et al. 2010, Mitrovich et al. 2010, Underwood and Quinn 2010, Houdeshell et al. 2011, Matsuda et al. 2011, Mustafa et al. 2011, Unstad 2012, Moranz et al. 2013, Verble 2013). Many studies report an initial decline in ant abundances and species richness after a fire, but long term sampling has determined that communities can recover after several years (Underwood and Quinn 2010, Matsuda et al. 2011, Verble 2013).

Others report that ants respond indirectly to prescribed fire owing to overall habitat alteration (Andersen 1995, York 2000, Farji-Brener et al. 2002, Hoffman and Andersen 2003, Mitrovich et al. 2010). Fire severity increases on south and southwest 
facing slopes (Weatherspoon and Skinner 1995, Alexander et al. 2006) resulting in a greater degree of habitat alteration from an ant's perspective. Topographic position (e.g. aspect and slope position) may be a relevant variable to explain the effect on ant abundance and community assemblage.

Other studies use functional groups to gauge ecological effects of prescribed burning. In a review of the responses of ant functional groups to prescribed burning in Australia, Hoffman and Andersen (2003) described that dominant ants in the subfamily increased after fire along with hot climate specialists and opportunists, with a decline in cryptic species. These findings are corroborated by research in the U.S. (Izhaki et al. 2001, Stephens and Wagner 2006, Moranz et al. 2013). This study includes an analysis of ant functional groups in order to add to the growing body of literature documenting ecological responses of ants to prescribed fire. To bolster ecological understanding of ant community's effects on site-specific ecological processes, I categorized ants into nesting groups and size classes.

\section{Methods}

Study site

This study took place in the Joint Fire Science Project (JFSP) area in the Missouri Ozarks. Sites were located at Logan Creek and Clearwater Creek Conservation Areas in Reynolds County, Missouri in the Current River Hills Ecoregion in the Missouri Ozark Highlands (Fig. 3.1). Specifically, this study is associated with the Black River Hills Oak-Pine Woodland/Forest Hills land type characterized by cherty, rocky soils with Roubidoux and Gasconade rock formations, rolling hills and steep slopes (Nigh and 
Schroeder 2002). Stocking of oak-hickory (Quercus- Carya) and oak-pine (Quercus-

Pinus echinata) forests was high at the initiation of this study in 2001 (Table 3.1), and no fire had been documented in the region for at least 40 years.

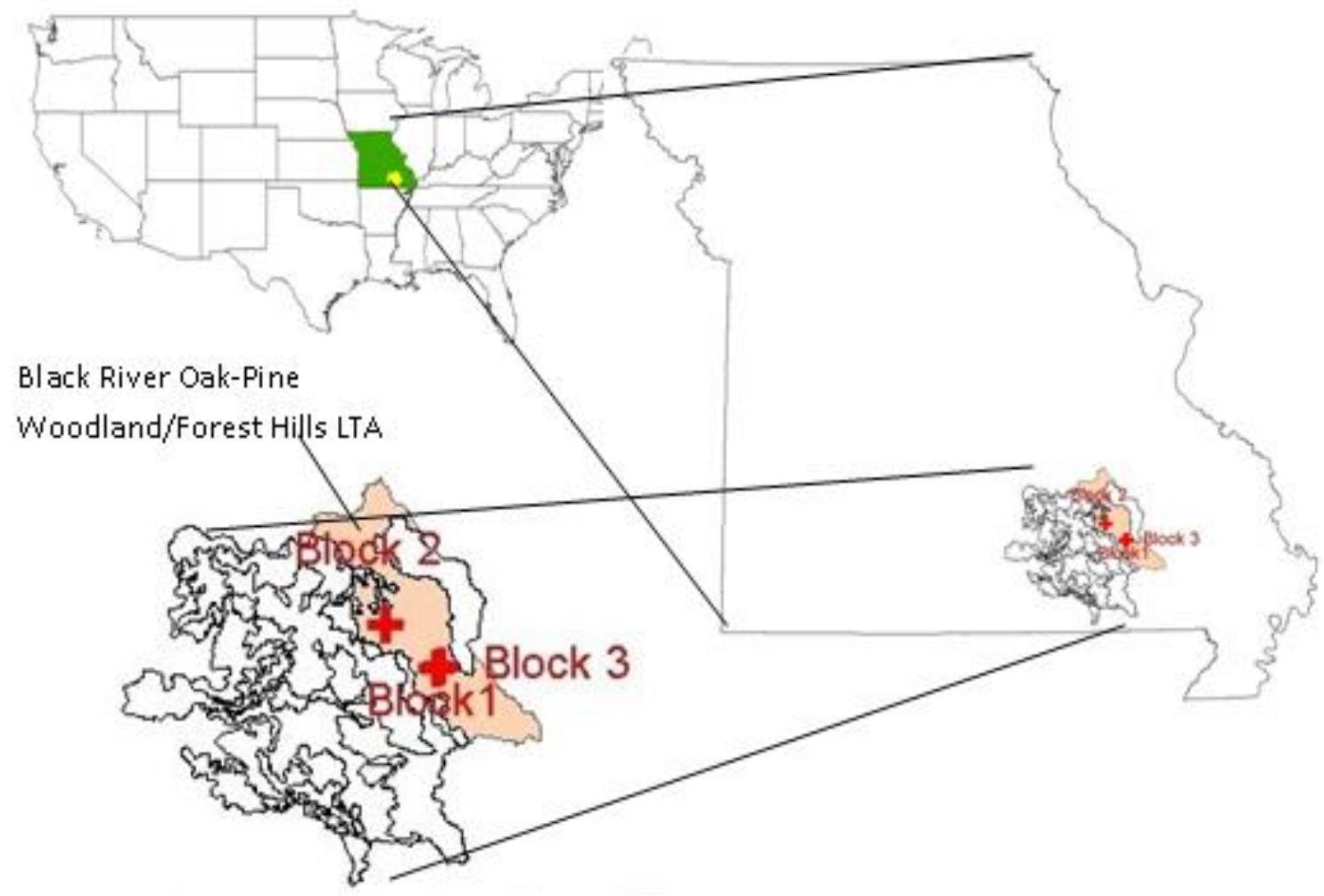

Fig. 3.1. Location of the Joint Fire Science Project (JFSP) study area in the Missouri Ozarks. The two blocks, Logan Creek and Clearwater Creek Conservation Areas. are located in the Black River Oak-Pine Woodland/Forest Hills Land Type Association. 
Table 3.1. Pretreatment and post-fire tree density, basal area and Gingrich (1976) stocking level at the study site. Adapted from Kinkead (2013).

\begin{tabular}{|c|c|c|c|c|c|c|c|c|c|}
\hline & \multicolumn{3}{|c|}{ Trees per hectare } & \multicolumn{3}{c|}{ Basal Area $\left(\mathbf{m}^{2} / \mathbf{h a}\right)$} & \multicolumn{3}{c|}{ Percent Stocking } \\
\hline Year & $\mathbf{2 0 0 1}$ & $\mathbf{2 0 0 3}$ & $\mathbf{2 0 0 6}$ & $\mathbf{2 0 0 1}$ & $\mathbf{2 0 0 3}$ & $\mathbf{2 0 0 6}$ & $\mathbf{2 0 0 1}$ & $\mathbf{2 0 0 3}$ & $\mathbf{2 0 0 6}$ \\
\hline Control & 866.4 & 784.6 & 750.0 & 24.6 & 24.2 & 25.6 & 94.7 & 92.1 & 95.9 \\
\hline Burn & 914.8 & 647.9 & 527.1 & 24.1 & 22.8 & 22.0 & 94.1 & 86.4 & 81.9 \\
\hline
\end{tabular}

\section{Experimental design}

Three 24 ha blocks were established in 2001 in order to evaluate forest changes after harvesting, burning and their combination. Blocks were divided into four treatments including harvest, burn, harvest/burn and control. Each treatment was again split to include an aspect/slope position: ridge tops (slopes $<8 \%)$, north $\left(315^{\circ}-45^{\circ}\right)$, and southfacing slopes $\left(135^{\circ}-225^{\circ}\right)$. Experimental prescribed fires were implemented in burn and harvest burn treatments in 2003 in all blocks, in 2005 for block 1 and 2 and in 2006 in block 3. For the purposes of this study, only the burn and control treatments were considered. Pretreatment stocking levels in burn units and control plots respectively were $94.1 \%$ and $94.7 \%$ and after the second fire at $81.9 \%$ and $95.9 \%$ (Table 3.1). Percent canopy openness was recorded in tandem with this study using photographs taken with a fisheye lens and was found to be significantly different between burns and controls $(p=0.0002)($ Kinkead 2013). See Kinkead (2013) for details on overstory and herbaceous vegetation. 


\section{Ant sampling}

Ant sampling was spatially coordinated with the pre-established vegetation plots. Permanent vegetation plots include $215 \mathrm{~m}$ long transects that run along contour lines in each treatment/aspect combination with three randomly placed over story plots. Within each overstory plot there is a grid of $1 \mathrm{x} 1$ meter vegetation plots that have been randomly assigned; the first six were used for vegetation sampling in July 2011 (see Kinkead et al. in press) (Fig. 3.2). Ants were collected using pitfall traps consisting of two $~ 500 \mathrm{~mL}$ plastic containers, one set inside the other, a solution of $300 \mathrm{~mL}$ distilled water and 100 $\mathrm{mL}$ of propylene glycol, and a plastic plate $36 \mathrm{~cm}$ in diameter, upside down, with 2 long nails used as a rain cover. Six pitfall traps were placed one meter to the south of each $1 \mathrm{x} 1$ meter vegetation plot within the overstory plots. The traps were deployed for two weeks in July of 2011 then collected and taken to the laboratory where ants were separated from dirt and debris, sorted from other arthropods then identified to species. All specimens were preserved in 1-dram vials containing $80 \%$ ethanol. Ants of the genus Solenopsis were treated as one group as they were abundant, very minute and made up only two possible species with similar ecological behavior. Species Aphaenogaster caroleninsis and the undescribed species temporarily named Aphaenogaster $n=19$ ( $n=19$ refers to chromosome number of the haploid karyotype of this species, for further details see Umphrey (1996)), are currently in a state of taxonomic flux, and were therefore lumped as well. Voucher specimens were confirmed by an expert ant taxonomist and will be deposited into the University of Missouri’s Entomology museum. 


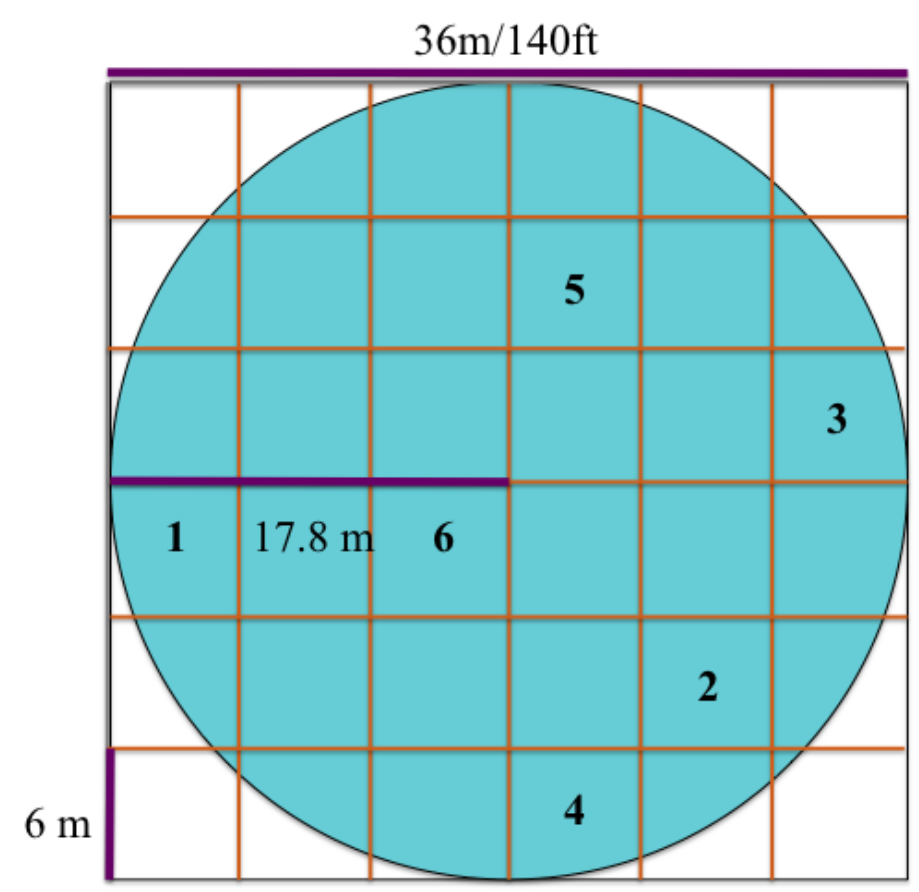

Fig. 3.2. Overstory plot vegetation plot. Pitfall traps were placed one meter north of each $1 \mathrm{x} 1$ meter (numbered 1-6) randomly placed on a $36 \mathrm{~m}^{2}$ grid.

Functional groups, nesting groups and size classes

To develop a more complete understanding of the response of ants to prescribed burning, ants were categorized into functional groups, nesting groups and size classes and analyzed for differences between treatments and aspect/slope position (Table 3.2). Functional groups are based on Andersen's (1995) scheme based on disturbance, stress and dominance, a useful model to understand ecological dynamics at a biogeographical scale (see Table 2.2, chapter 2). Although nest preference can vary by species, nesting groups were assigned to species based on their general requirements and their most commonly observed nest sites (Coovert 2005, James Trager, personal communication). Ants were sorted into arboreal (AR), cavity/litter (CL), soil (SO), and wood (WO) nesters. Ant size was also determined and ranked for each species through the use of ant identification keys and primary literature (Creighton 1950, Coovert 2005, Snelling and 
Snelling 2007, Trager et al. 2007, Kallal and LaPolla 2012, MacGown 2013). Small ants

(S) were $>3.49 \mathrm{~mm}$, medium ants (M) were $3.5-5.99 \mathrm{~mm}$ and larger ants were $>6 \mathrm{~mm}$.

Table 3.2. Subfamilies and species found at JFSP site, Logan Creek and Clearwater Creek Conservation Areas and their corresponding functional group, nesting group, and size class designations.

\begin{tabular}{|c|c|c|c|c|}
\hline Subfamily & Species & $\begin{array}{l}\text { Functional } \\
\text { Group }\end{array}$ & $\begin{array}{l}\text { Nesting } \\
\text { Group }\end{array}$ & $\begin{array}{l}\text { Size } \\
\text { Class }\end{array}$ \\
\hline Amblyoponinae & Stigmatomma pallipes Haldeman & $\mathrm{CR}$ & $\mathrm{CL}$ & $\mathrm{M}$ \\
\hline Dolichoderinae & Tapinoma sessile Say & $\mathrm{OP}$ & $\mathrm{CL}$ & $\mathrm{S}$ \\
\hline \multirow[t]{15}{*}{ Formicinae } & Brachymyrmex depilis Emery & $\mathrm{CR}$ & CL & $S$ \\
\hline & Camponotus americanus Mayr & $\mathrm{SC}$ & SO & $\mathrm{L}$ \\
\hline & Camponotus chromaioides Bolton & $\mathrm{SC}$ & WO & $\mathrm{L}$ \\
\hline & Camponotus nearcticus Emery & $\mathrm{SC}$ & AR & $\mathrm{M}$ \\
\hline & $\begin{array}{l}\text { Camponotus pennsylvanicus } \\
\text { DeGreer }\end{array}$ & $\mathrm{SC}$ & AR & $\mathrm{L}$ \\
\hline & Camponotus snellingi Bolton & $\mathrm{SC}$ & $\mathrm{AR}$ & $\mathrm{M}$ \\
\hline & Camponotus subarbatus Emery & SC & SO & $\mathrm{M}$ \\
\hline & Formica dolosa Buren & OP & SO & $\mathrm{L}$ \\
\hline & Formica pallidefulva Latreille & OP & SO & $\mathrm{M}$ \\
\hline & Formica rubicunda Emery & OP & SO & $\mathrm{L}$ \\
\hline & Formica subintegra Emery & OP & SO & $\mathrm{L}$ \\
\hline & Formica subsiricea Say & OP & SO & $\mathrm{L}$ \\
\hline & Nylanderia faisonensis Forel & OP & $\mathrm{CL}$ & S \\
\hline & Polyergus montivagus Smith* & SP & SO & $\mathrm{L}$ \\
\hline & Prenolepis imparis Say & $\mathrm{CCS}$ & SO & M \\
\hline \multirow[t]{19}{*}{ Myrmicinae } & Aphaenogaster fulva Roger & OP & $\mathrm{CL}$ & $\mathrm{M}$ \\
\hline & Aphaenofaster lamellidens $\mathrm{Mayr}$ & OP & WO & $\mathrm{M}$ \\
\hline & Aphaenogaster mariae Wheeler & OP & AR & M \\
\hline & $\begin{array}{l}\text { Aphaenogaster carolinensis } \\
\text { Wheeler and Aphaenogaster } \mathrm{n}=19 \text {, } \\
\text { see Umphrey (1996) }\end{array}$ & OP & $\mathrm{WO} / \mathrm{SO}$ & $\mathrm{M}$ \\
\hline & $\begin{array}{l}\text { Aphaenogaster tennesseeinsis } \\
\text { Mayr }\end{array}$ & OP & $\mathrm{AR}$ & $\mathrm{M}$ \\
\hline & Aphaenogaster treatae Forel & OP & $\mathrm{SO}$ & $\mathrm{L}$ \\
\hline & Crematogaster ashmeadi Mayr & GM & $\mathrm{AR}$ & $\mathrm{S}$ \\
\hline & Crematogaster lineolata Say & GM & SO & $\mathrm{M}$ \\
\hline & Monomorium minimum Buckley & GM & SO & $\mathrm{S}$ \\
\hline & Myrmecina americana Emery & CCS & $\mathrm{CL}$ & $\mathrm{S}$ \\
\hline & Myrmica americana Weber & OP & SO & $\mathrm{M}$ \\
\hline & Myrmica pinetorum Wheeler & OP & SO & $\mathrm{M}$ \\
\hline & Myrmica punctiventris Roger & OP & $\mathrm{CL}$ & $\mathrm{M}$ \\
\hline & Pheidole dentata Mayr & GM & SO & $\mathrm{S}$ \\
\hline & Pheidole tysoni Forel & GM & SO & $\mathrm{S}$ \\
\hline & $\begin{array}{l}\text { Solenopis molesta Say and } S . \\
\text { texana Forel }\end{array}$ & $\mathrm{CR}$ & $\mathrm{SO}$ & $\mathrm{S}$ \\
\hline & Stenamma impar Forel & $\mathrm{CCS}$ & SO & $S$ \\
\hline & Strumigenys ornata Mayr & $\mathrm{CR}$ & $\mathrm{CL}$ & $\mathrm{S}$ \\
\hline & Strumigenys talpa Weber & $\mathrm{CR}$ & CL & $\mathrm{S}$ \\
\hline
\end{tabular}




\begin{tabular}{|l|l|c|c|c|}
\hline & Temnothorax curvispinosus Mayr & CCS & CL & S \\
\hline & Temnothorax pergandei Roger & CCS & SO & S \\
\hline & Temnothorax schaumii Roger & CCS & AR & S \\
\hline & Temnothorax texanus Wheeler & CCS & SO & S \\
\hline & $\begin{array}{l}\text { Trachymyrmex septentrionalis } \\
\text { McCook }\end{array}$ & TCS & SO & M \\
\hline Ponerinae & Ponera exotica Smith & CR & CL & S \\
\hline & Ponera pennsylvanica Buckley & CR & SO & S \\
\hline Proceratiinae & Proceratium crassicorne Emery & CR & SO & S \\
\hline
\end{tabular}

\section{Statistical analysis}

Abundance and diversity

Total ant abundances and observed species richness were pooled by experimental unit (treatment by aspect) and used to calculate Shannon-Weiner ( $\left.H^{\prime}\right)$, Simpson's and Evenness indices (Table 2.4, see chapter 2). To account for species that were not detected due to sampling effort, an incidence-based, nonparametric species accumulation estimate (Chao2) and rare species (less than 10 individuals) were calculated using SPADE (Chao and Shen 2010). The Chao2 index uses "uniques", individuals that only occur in one experimental unit, and "duplicates", those individuals that occur in two experimental units, to estimate the number of species it would take to reach the asymptote in a species accumulation curve (Chao 1984, Colwell and Coddington 1994, Gotelli and Ellison 2013). Because ants should be treated more as representatives of a colony, their unit of diversity, instead of individuals, incidence-based species richness estimators, like the Chao2 index, are recommended for ant studies (Gotelli et al. 2011).

Diversity and abundance data was tested for normality (PROC UNIVARIATE, PROC GLM: Bartlett's test for homogeneity, SAS Institute, Inc. 2012) and log or rank transformed to meet assumptions of Analysis of Variance (ANOVA) (Conover and Iman 1981). To analyze differences in overall abundance, diversity, rare species, observed, estimated species richness and percent canopy openness, a mixed model ANOVA 
$(y=$ treatment|aspect) was used with block considered a random effect and treatment and aspect as fixed effects (PROC MIXED, SAS Institute, Inc. 2012). The goodness of fit was estimated using the Akaike Information Criterion. Diversity and abundance were regressed against percent openness (PROC REG) to test for an association with canopy cover.

Functional groups, nesting groups, size classes, and species

All ant categories, functional groups, nesting groups, size classes, and species, were sorted by frequency per trap (PROC SORT) and rank transformed (PROC RANK) (Conover and Iman 1981). Akaike Information Criterion was used to estimate goodness of fit. Individual categories and species were analyzed using mixed models (PROC MIXED) ANOVA; block was treated as a random factor and topographic position and treatment as fixed factors. A simple linear regression was used to test effects of canopy openness on species and category abundances per trap. All ANOVAs and regressions were conducted with SAS (SAS Institute, Inc. 2012).

Ant assemblages across treatments and years were assessed using Morisita Similarity, an index that uses the shared species between multiple communities to compare the similarity of those communities (Chao et al. 2008) using SPADE software (Chao and Shen 2010). This index and assess more than two communities at a time using all shared information between assemblages. Species data were further analyzed using Multi-Response Permutation Procedures (MRPP) and Nonmetric Multidimensional Scaling using PC-ORD, v. 6.0 (McCune and Mefford 1999) to show overall community responses to treatments. The nonparametric analysis, MRPP, is used to distinguish 
differences in composition of two or more communities within a priori groups like treatments (Mielke and Berry 2001). This procedure can be performed when data does not meet assumptions of normality (Zimmerman et al. 1985), a common scenario with ecological community data. This method uses a test statistic (T) to calculate between group or treatment separation and an agreement statistic (A) to evaluate within group homogeneity. P-values are generated using the Pearson type III distribution based on the test statistic. In order to minimize sampling bias of pitfall traps placed near a nest or foraging trail, abundances were transformed using a 6 point index (Andersen 1991, 1997). This index uses values to correspond to the following abundances: 0 ants $=0,1$ ant $=1,2-5$ ants $=2,6-10$ ants $=3,11-20$ ants $=4,21-50$ ants $=5,>50$ ants $=6$. I tested the null hypothesis that there was no difference among transformed abundances of species and species composition among treatments with the Sorensen similarity index. To illustrate the findings of the MRPP, I used NMS to explore dissimilarity between communities using the Sorensen coefficient. NMS uses an iterative technique to plot data based on ranked distances or dissimilarities between treatments. The measure of the departure from monotonicity in the relationship between dissimilarity of actual space and reduced ordinational space is called "stress"; the lower the stress, the more related to original ranked distances and the better the representation of dissimilarity between treatments.

\section{Results}

Abundance and diversity

A total of 19,470 ants among 44 species were sampled and identified with 9,391 in the burned area and 10,079 in the control (Fig. 3.3). Abundance per trap, species 
richness, rare species richness, Chao2, Shannon's diversity, nor Simpson's diversity indices were affected by treatment aspect/slope position (Table 3.3). When compared with the ridge slope position $(\mathrm{p}=0.0053)$ and south-facing slopes $(\mathrm{p}=0.0298)$, north facing aspects had more evenness in controls $(\mathrm{p}=0.0435)$. In addition, less variation in evenness was found on burned ridges compared to control ridges $(p=0.0128)$. Canopy openness in burned areas were found to be more open than control areas $(\mathrm{p}=0.0221)$ (Table 3.4) but no measure of abundance or diversity was correlated to canopy openness except observed species richness (Fig. 3.4).

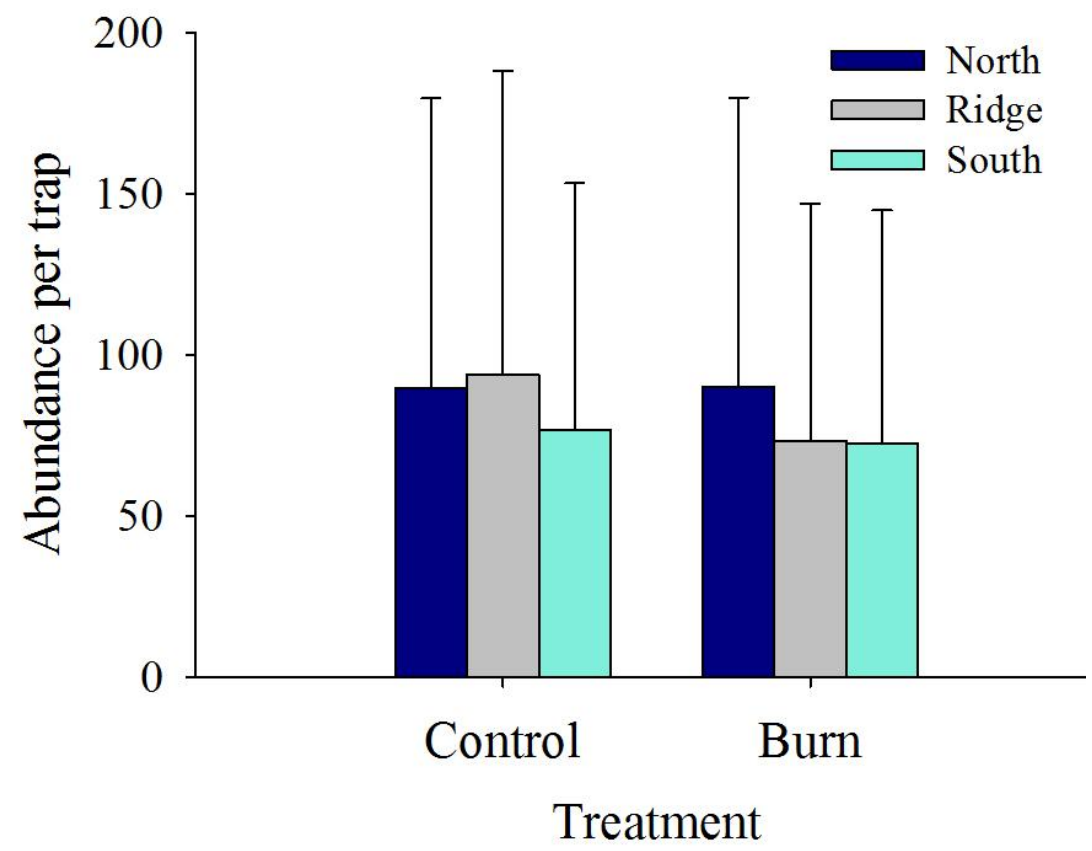

Fig. 3.3. Mean total abundance per trap for each aspect/slope position within treatment. Error bars show mean +1 standard error. 
Table 3.3. Diversity measures of ant assemblages by treatment and topographic position.

\begin{tabular}{|c|c|c|c|c|c|c|c|}
\hline \multicolumn{2}{|c|}{$\begin{array}{c}\text { Treatment and } \\
\text { Topographic Position }\end{array}$} & $\begin{array}{c}\text { Observed } \\
\text { Species } \\
\text { Richness }\end{array}$ & $\begin{array}{c}\text { Chao2 } \\
\text { Index }\end{array}$ & $\begin{array}{c}\text { Rare } \\
\text { Species } \\
(<\mathbf{1 0})\end{array}$ & $\begin{array}{c}\text { Shannon- } \\
\text { Weiner } \\
\text { Index* }\end{array}$ & $\begin{array}{c}\text { Simpson's } \\
\text { Index** }\end{array}$ & $\begin{array}{c}\text { Evenness } \\
\text { Index*** }\end{array}$ \\
\hline Control & North & 19.33 & 27.693 & 13.33 & 1.2513 & 0.4561 & 0.2172 \\
\hline Control & Ridge & 20.33 & 24.627 & 11.67 & 1.5213 & 0.3775 & 0.1807 \\
\hline Control & South & 22.33 & 29.843 & 10.67 & 1.9441 & 0.2335 & 0.1914 \\
\hline Burn & North & 23.00 & 35.210 & 13.00 & 1.7468 & 0.3042 & 0.2040 \\
\hline Burn & Ridge & 23.33 & 26.817 & 12.33 & 2.0164 & 0.2197 & 0.2117 \\
\hline Burn & South & 22.00 & 28.213 & 10.67 & 1.9406 & 0.2322 & 0.1927 \\
\hline
\end{tabular}

*The higher the index value the more diverse.

**The lower the index value the more diverse.

$* * *$ The lower the index value the more variation in the evenness.

Observed Species Richness vs Percent Canopy Openness

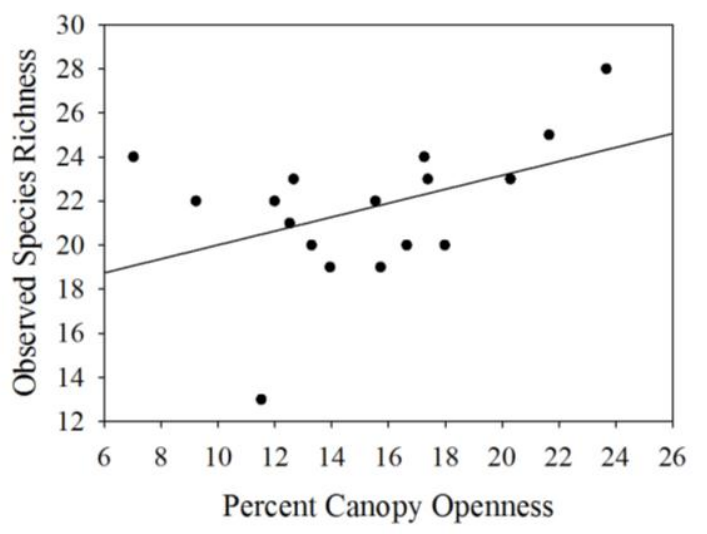

Fig. 3.4. Simple linear regression showing association between percent canopy openness and observed species richness.

Functional groups, nesting groups and size classes

The mixed model ANOVA showed significant results for functional groups, but not nesting groups or size classes. There were no differences in functional groups due to treatment (Fig. 3.5). There were more CCS on south-facing slopes of control plots than on north-facing slopes $(\mathrm{p}=0.022)$ and ridge tops $(\mathrm{p}=0.0268)$ with a significant treatment*aspect/slope position interaction (Fig. 3.6). CR were more common on south- 
facing slopes than ridge tops $(\mathrm{p}=0.0255)$ but showed no differences with north-facing slopes. Likewise, GM were frequently encountered in traps on south-facing slopes when compared with north-facing slopes $(\mathrm{p}=0.0363)$.

Table 3.4. Percent canopy openness recorded at the study area in July 2011 at the Joint Fire Science Project study area (Kinkead 2013).

\begin{tabular}{cr}
\hline Treatment/ Topographic position & \% Canopy Openness \\
\hline Burn* & 17.81 \\
\hline North & 18.84 \\
\hline Ridge & 17.88 \\
\hline South & 17.05 \\
Control* & 12.87 \\
\hline North & 11.13 \\
Ridge & 14.15 \\
\hline South & 13.33 \\
\hline
\end{tabular}

*indicates a significant difference

Simple linear regression revealed that some groups are sensitive to canopy openness. $\operatorname{CCS}(\mathrm{p}=0.0270)$ and $\mathrm{GM}(\mathrm{p}=0.0104)$ both show a positive correlation to increasing canopy openness (Fig. 3.7). There were no significant differences in nesting groups due to treatment (Fig. 3.8) or topographic position (Fig. 3.9). Arboreal and soil nesting ants show a positive association with canopy openness (Fig. 3.10). There were no significant differences in size classes due to treatment (Fig. 3.11) or topographic position (Fig. 3.12). Small ants ( $\mathrm{p}=0.0154)$ had a positive relationship with canopy openness (Fig. 3.13). 


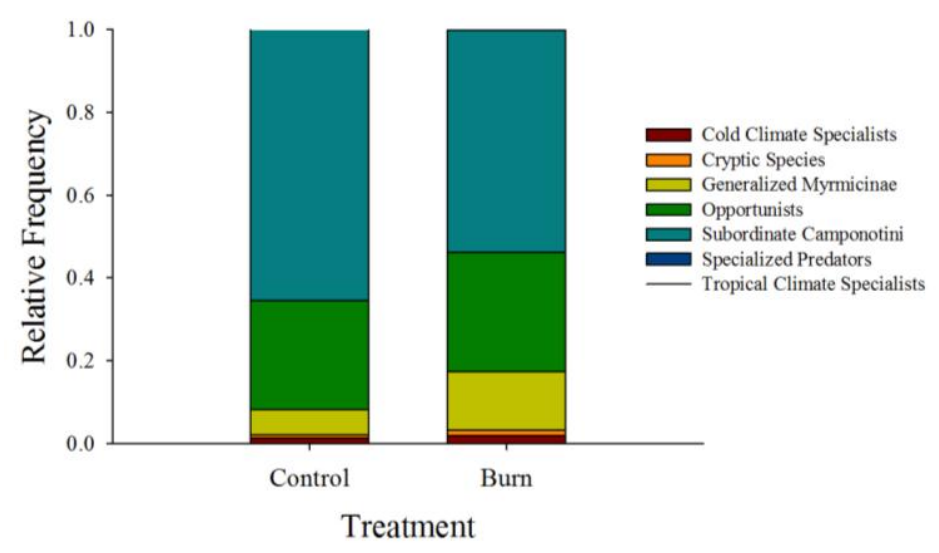

Fig. 3.5. Relative frequencies of functional groups across treatment.

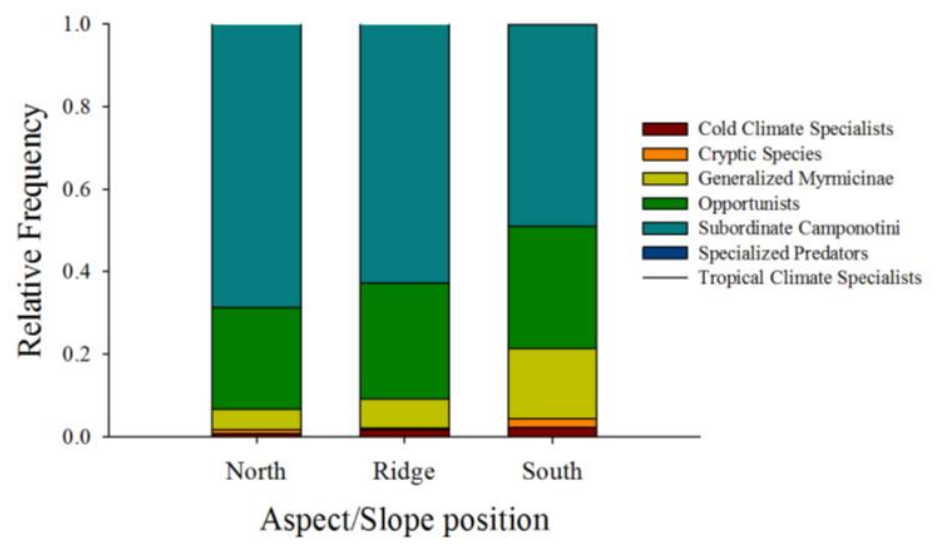

Fig. 3.6. Relative frequencies of functional groups across aspect/slope position.
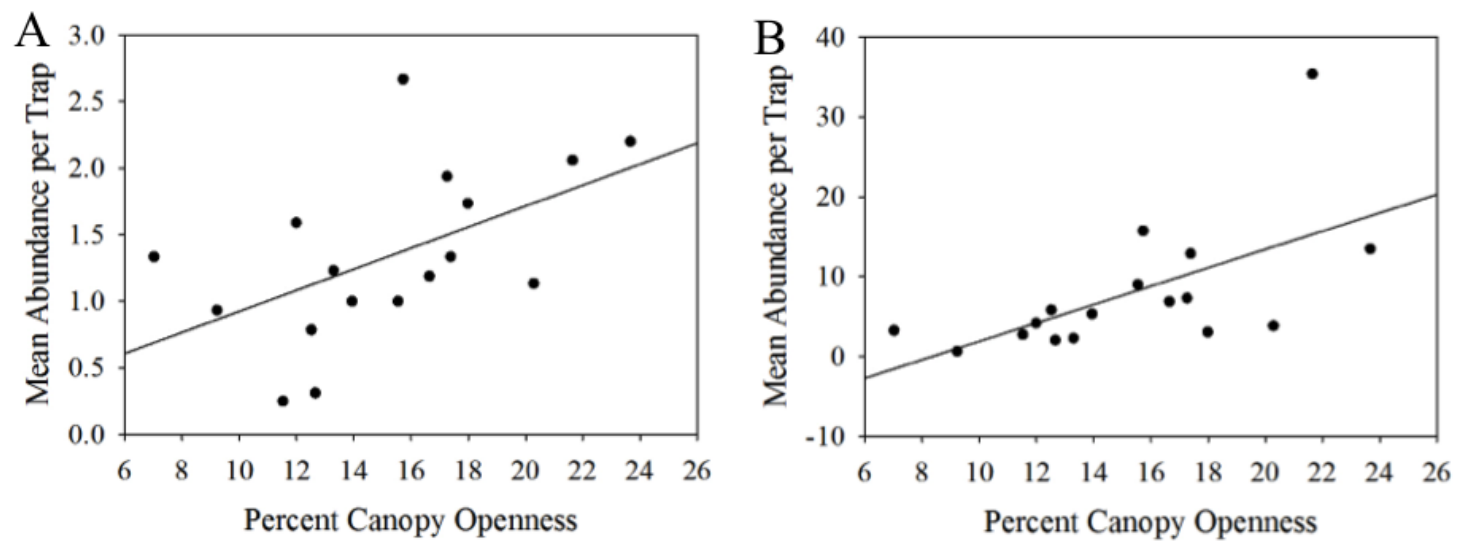

Fig. 3.7. Simple linear regression showing association between percent canopy openness and mean abundance per trap of A) Cold Climate Specialists and B) Generalized Myrmicinae. 


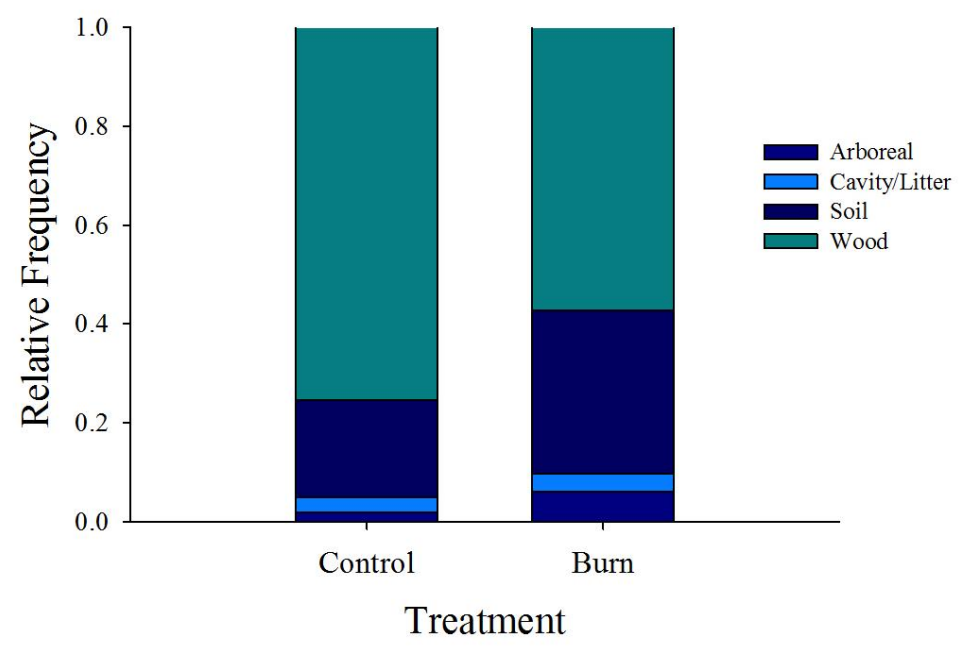

Fig. 3.8. Relative frequencies of nesting groups across treatments.

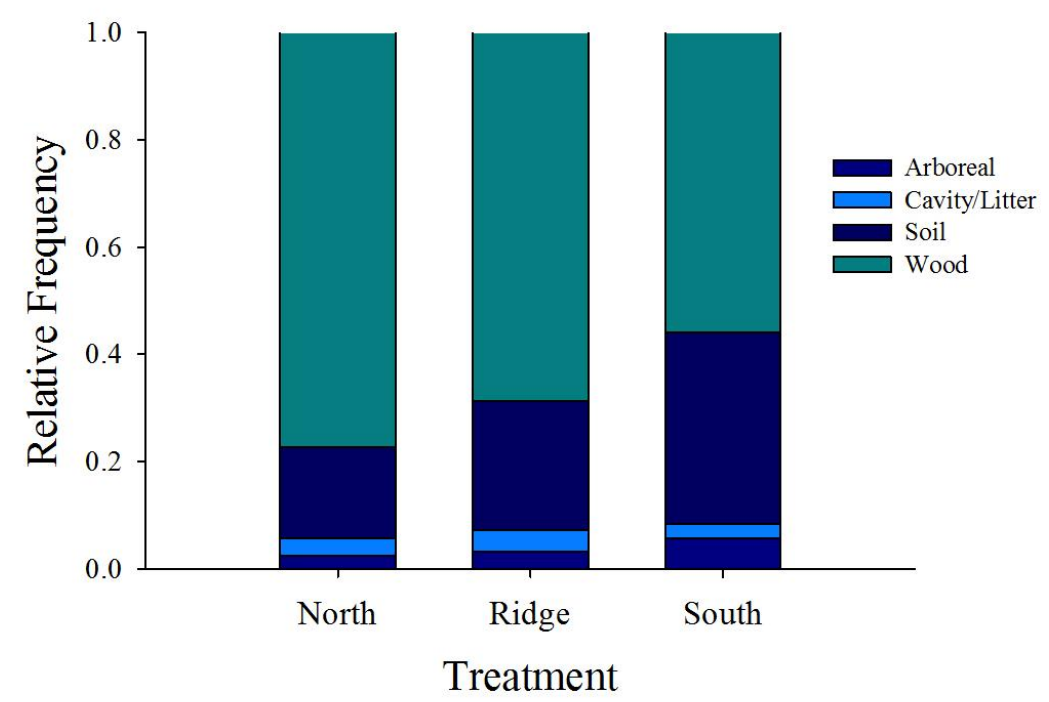

Fig. 3.9. Relative frequencies of nesting groups across aspect/slope position. 
A

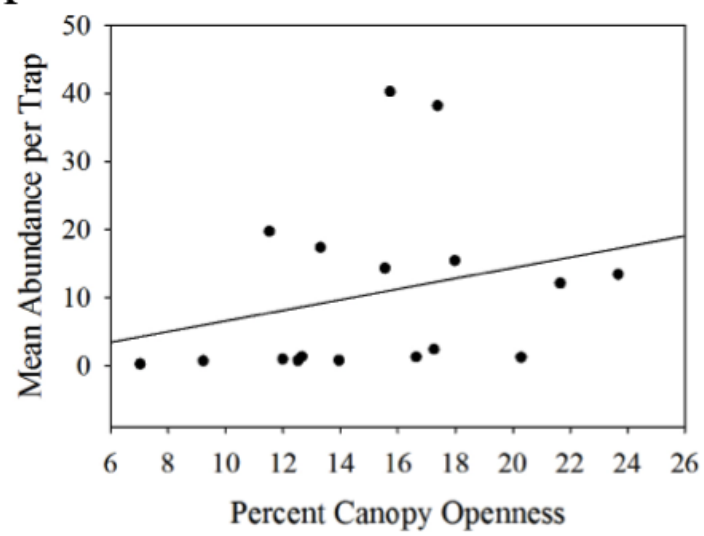

$\mathrm{B}$

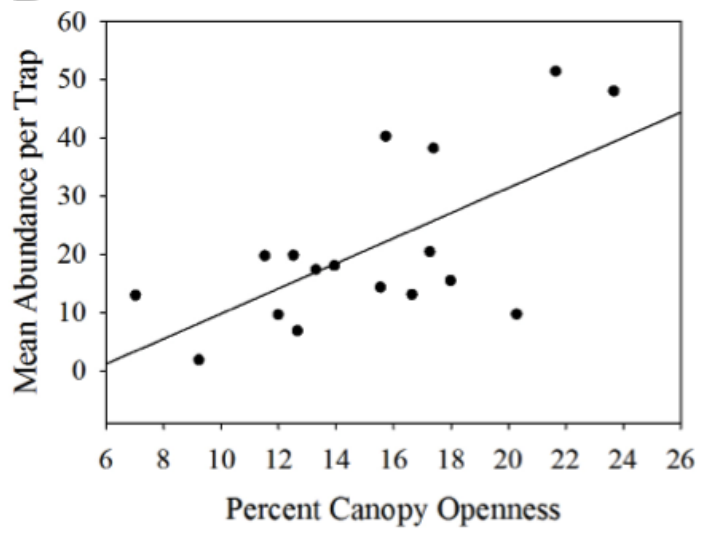

Fig. 3.10. Simple linear regression showing association between percent canopy openness and mean abundance per trap of A) arboreal nesters and B) soil nesters.

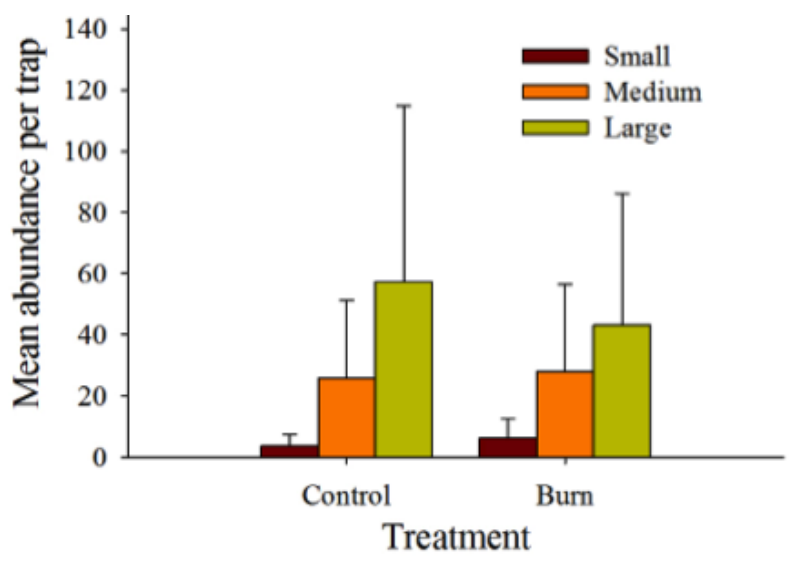

Fig. 3.11. Abundance per trap for small, medium and large size classes by treatment. Error bars show mean +1 standard error.

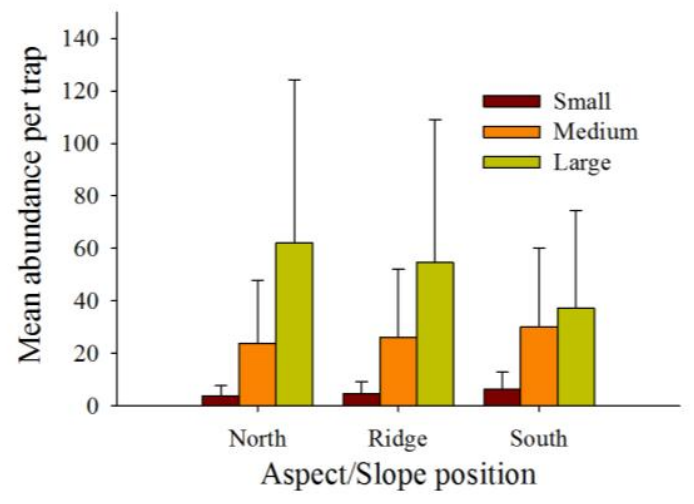

Fig. 3.12. Abundance per trap for small, medium and large size classes by slope/aspect position. Error bars show mean +1 standard error. 


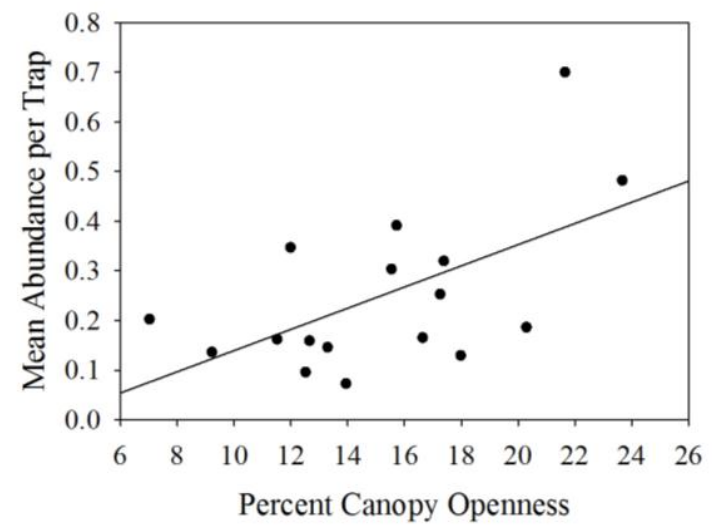

Fig. 3.13. Simple linear regression showing association between percent canopy openness and mean abundance per trap of small ants.

\section{Species}

Several ant species were dominant across all treatments and aspects; in order of numerical dominance these ant species included Camponotus chromaiodes, Aphaenogaster carolinensis/n19, Camponotus americanus Crematogaster lineolata, and Formica pallidefulva (Fig. 3.14). Few significant differences were found in ant species abundance per trap between treatments and topographic position (Fig. 3.15). Burn units contained more Myrmica americana $(\mathrm{p}=0.046)$ and Pheidole dentata, which were found exclusively in the south burns (south burn>north burn, ridge burn and south control, $\mathrm{p}=0.0162, \mathrm{p}=0.0092$, and $\mathrm{p}=0.0092$, respectively). The Formicine Formica dolosa occurred more often on south facing slopes than northern slopes $(p=0.0303)$ as did Temnothorax pergandei $(\mathrm{p}=0.0079)$. Nylanderia faisonensis $(\mathrm{p}=0.0079)$. Formica subsiricea was found more frequently in north $(\mathrm{p}=0.0167)$ and ridges $(\mathrm{p}=0.0054)$ than on south-facing slopes. The thief ants, Solenopsis spp., preferred south slopes when compared to ridge tops $(\mathrm{p}=0.0031)$ and north-facing slopes $(\mathrm{p}=0.0136)$ of controls with a treatment by aspect/slope position interaction. The cavity nesting ant, Temnothorax 
curvispinosus was abundant on north-facing slopes of controls compared to ridge tops $(\mathrm{p}=0.0382)$ and south slopes $(\mathrm{p}=0.0072)$. They also are found on burned ridges to control ridges $(\mathrm{p}=0.0210)$. Complex interactions between treatment and topographic position $(\mathrm{p}=0.0032)$ explained differences in Myrmecina americana. In addition, simple linear regression showed that Crematogaster lineolata $(\mathrm{p}=0.0257)$, Formica pallidefulva $(\mathrm{p}=0.0159)$, Myrmica pinetorum $(\mathrm{p}=0.0187)$, and Temnothorax pergandei $(\mathrm{p}=0.0206)$ were all positively correlated to canopy openness; one species group, Aphaenogaster carolinensis $/ \mathrm{n}=19$, was negatively correlated with canopy openness ( $\mathrm{p}=0.0471)$ (Fig. 3.16).

Results from the MRPP indicate that there is a difference in assemblages of ants among aspects (Table 3.5). The closer the test statistic is to 0 the less separation there is between treatments or topographic position. The low agreement values show that twithin groups, there is little similarity when compared with all groups. In other words all groups are similar except south aspects versus north aspects $(\mathrm{p}=0.015)$. MRPP results are visualized in the NMS assessment showing no distinct groups based on treatment in 3 dimensional space (Fig. 3.18) and showing some difference between aspects (Fig. 3.19). 

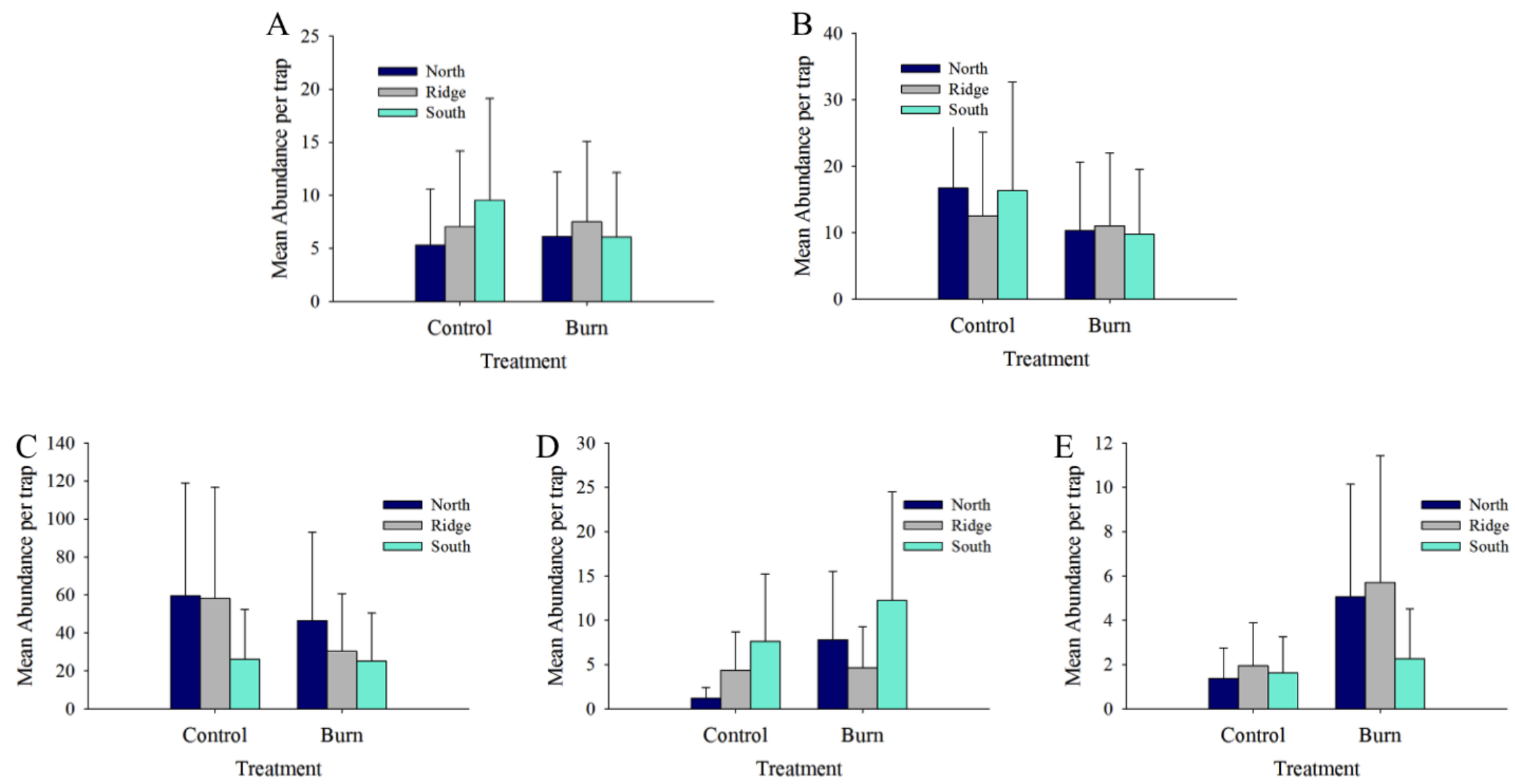

Fig. 3.14. Ants that were found commonly across all treatments and topographic positions including A) Camponotus americanus, B) Aphaenogaster group, C) Camponotus chromaiodes, D) Crematogaster lineolata, and E) Formica pallidefulva. Error bars indicate the mean +1 standard error. 

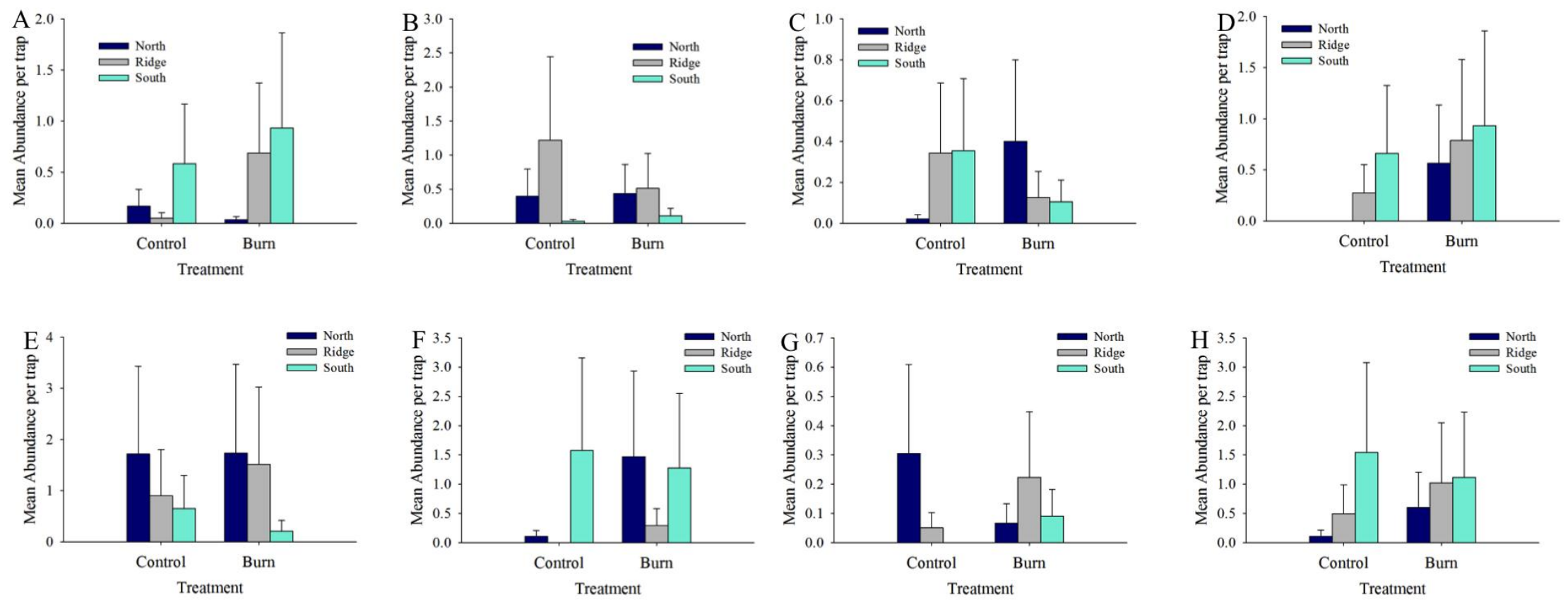

Fig. 3.15. Species of ants that responded to treatment, topographic position or their interaction including A) Formica dolosa, B) Formica subsiricea, C) Myrmecina americana, D) Myrmica pinetorum, E) Nylanderia faisonensis, F) Solenopsis spp., G) Temnothorax curvispinosus, and H) T. pergandei. Error bars indicate the mean +1 standard error. 


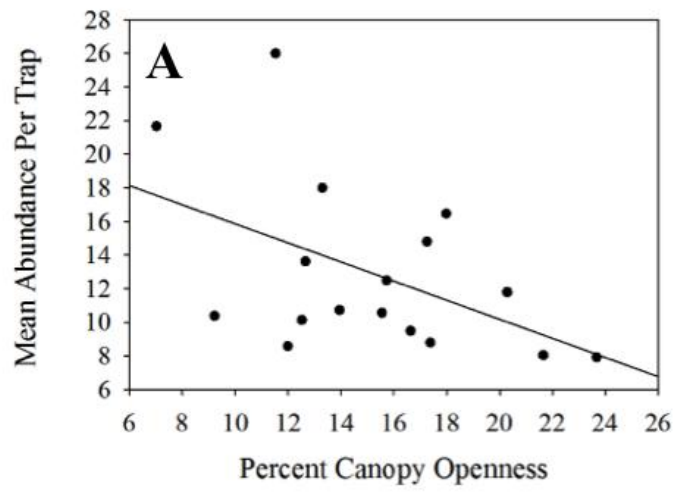

Formica dolosa vs Percent Canopy Openness

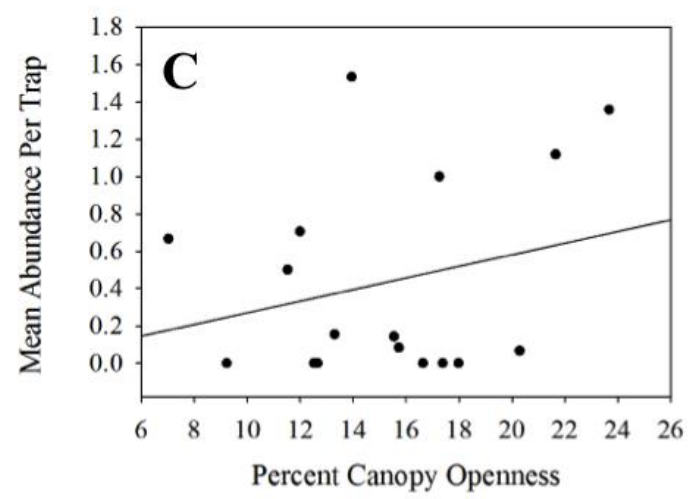

Temnothorax pergandei vs Percent Canopy Openness

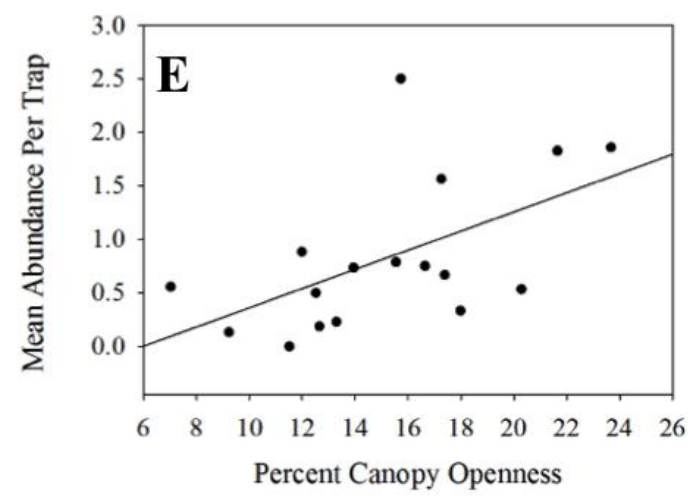

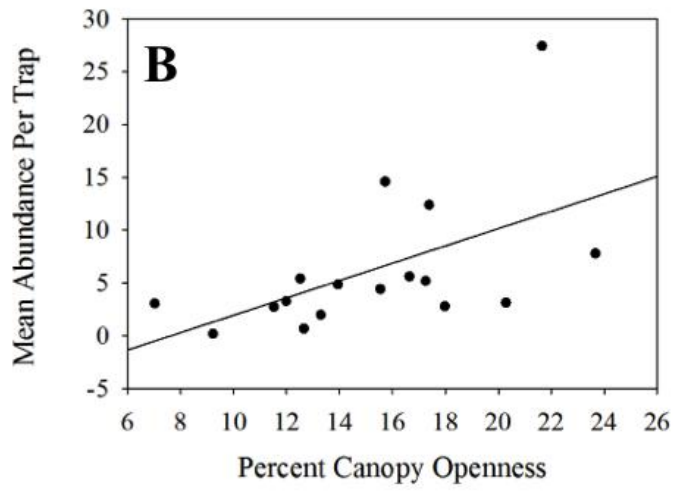

Myrmica pinetorum vs Percent Canopy Openness

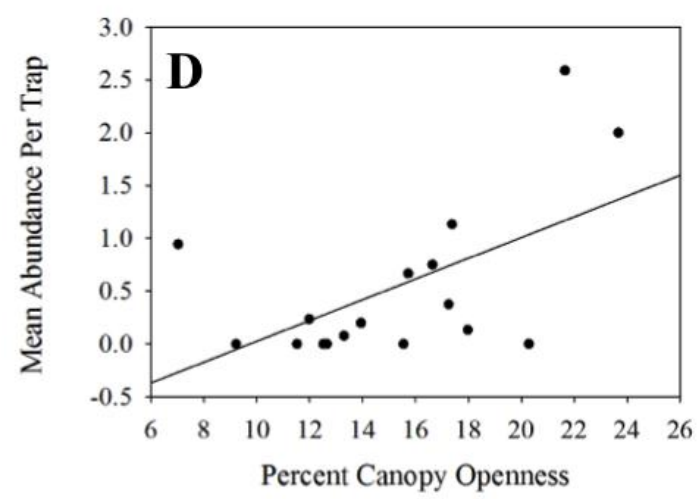

Fig. 3.16. Simple linear regression showing correlation between percent canopy openness and mean abundance per trap of A) Aphaenogaster carolinensis/n19, B) Crematogaster lineolata, C) Formica dolosa, D) Myrmica pinetorum, and E) Temnothorax pergandei. 

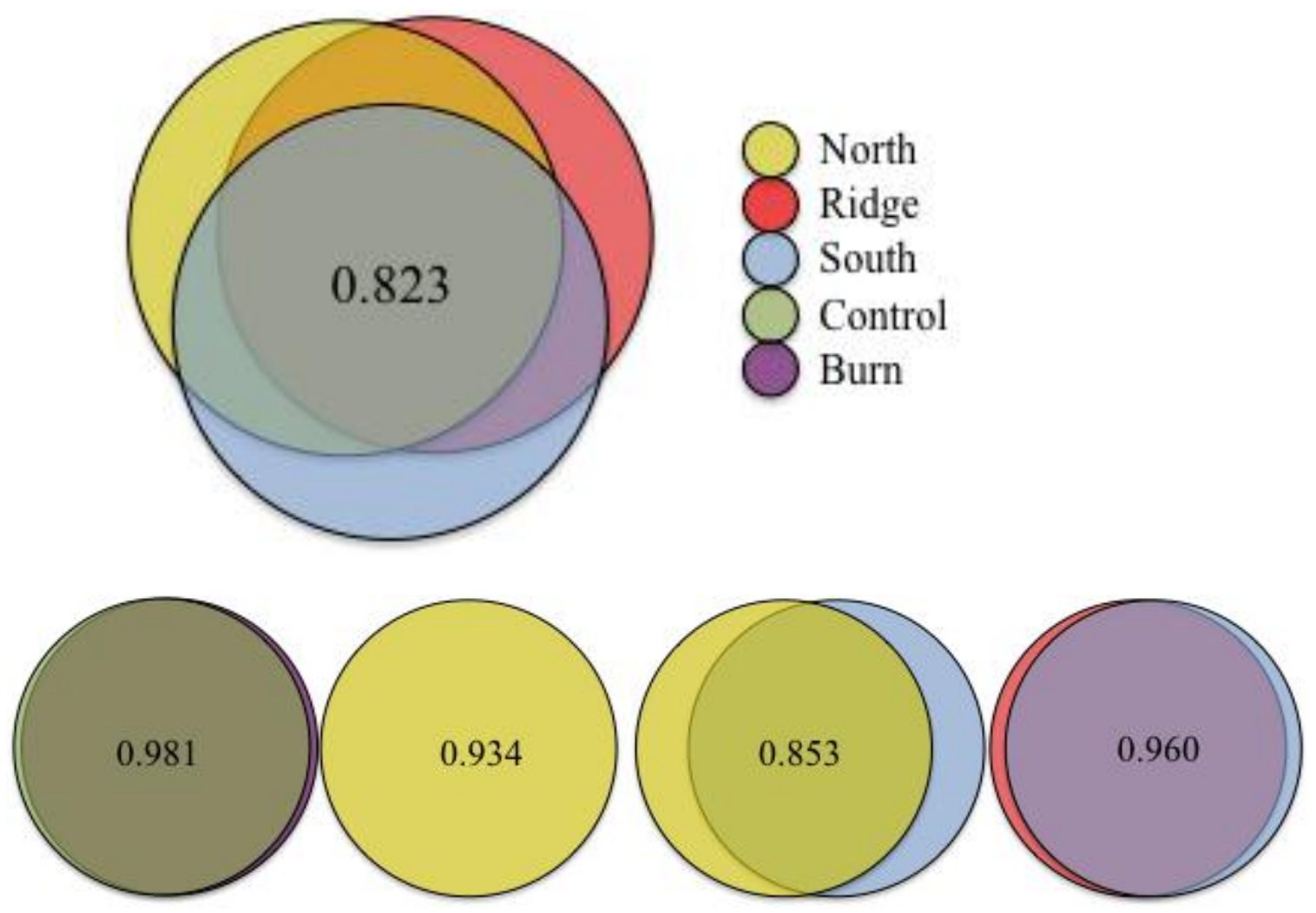

Fig. 3.17. Morisita similarity indices between all topographic positions combined (top), and pairwise comparisons between treatments and topographic positions.

Table 3.5. Results from the multiple response permutation procedure performed between treatments and topographic position. The test statistic (T) is used to calculate between group or treatment separation (the more negative a value signifies a greater degree of separation). The agreement statistic (A) evaluates within group homogeneity (when $A=1$ communities are perfectly similar). P-values are generated using the Pearson type III distribution based on the test statistic.

\begin{tabular}{|c|c|c|c|}
\hline Treatments & Test statistic (T) & $\begin{array}{c}\text { Agreement } \\
\text { Statistic (A) }\end{array}$ & p-value \\
\hline Control vs. Burn & -0.722 & 0.012 & $\mathrm{P}=0.211$ \\
\hline North vs. Ridge & -2.501 & 0.066 & $\mathrm{p}=0.015^{*}$ \\
\hline North vs. South & -0.935 & 0.024 & $\mathrm{p}=0.167$ \\
\hline Ridge vs. South & -0.293 & 0.007 & $\mathrm{p}=0.352$ \\
\hline $\begin{array}{l}\text { All Topographic } \\
\text { Positions }\end{array}$ & -1.744 & 0.0412 & $\mathrm{p}=0.054$ \\
\hline
\end{tabular}

*Indicates significance. 


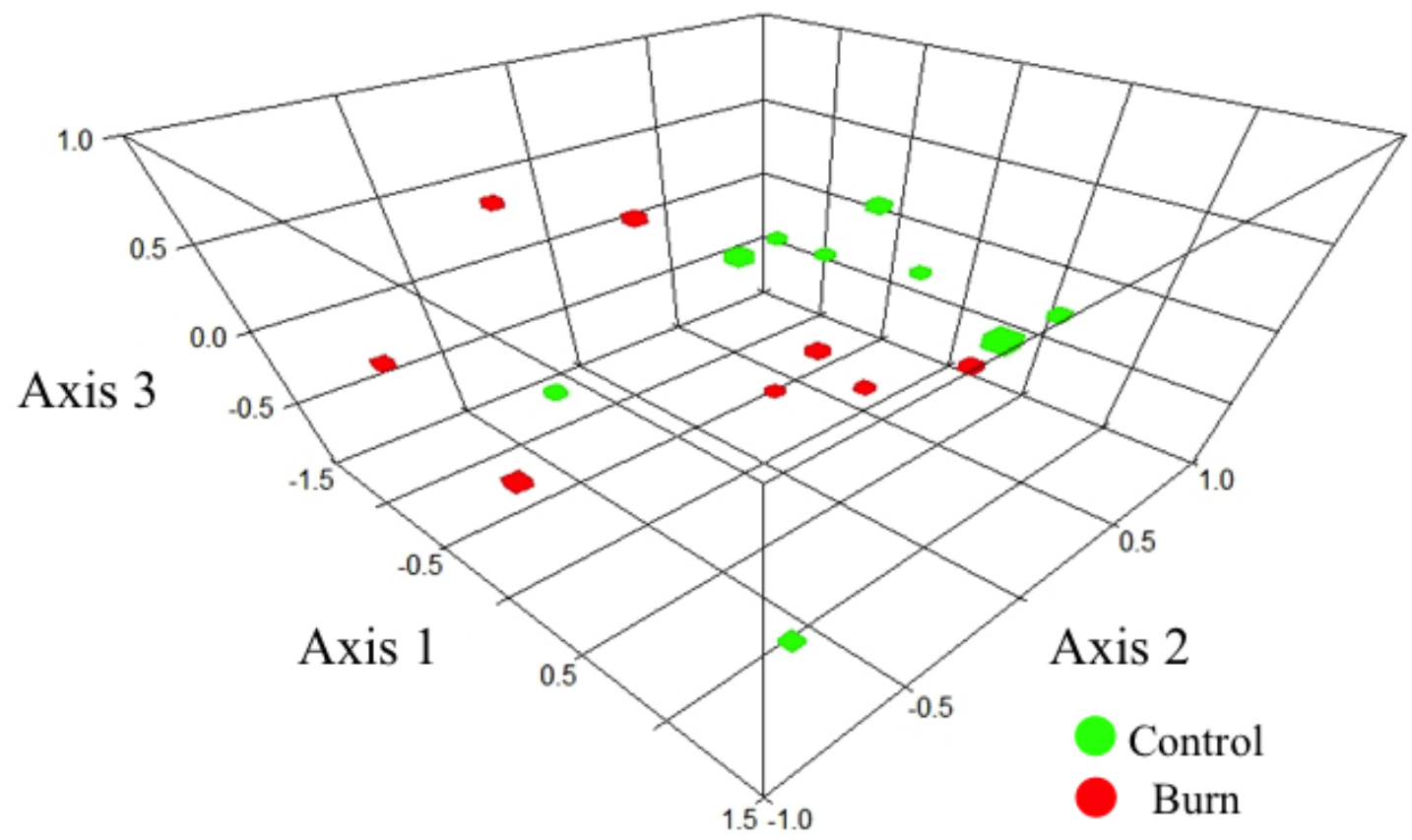

Fig. 3.18. Nonmetric multidimensional scaling ordination of treatments.

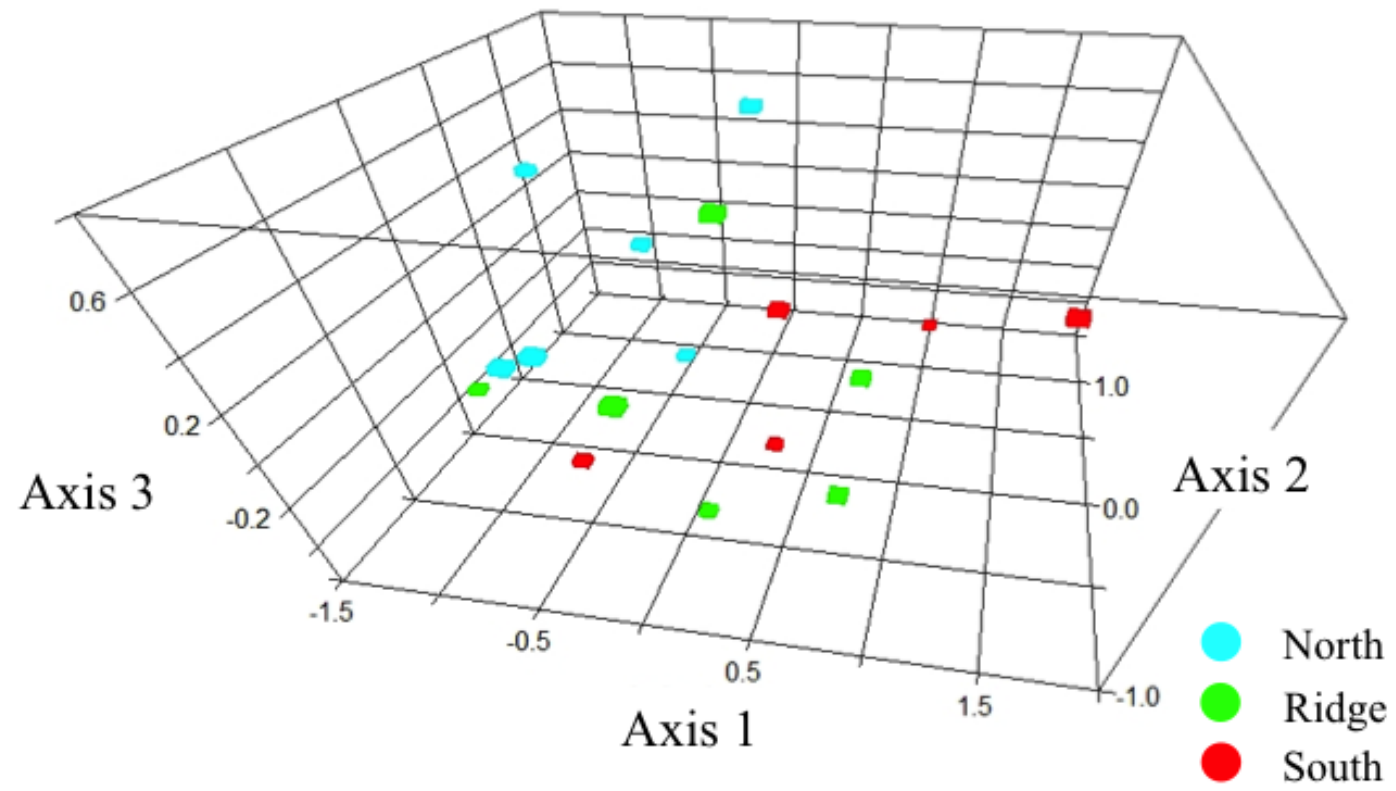

Fig. 3.19. Nonmetric multidimensional scaling ordination of topographic position. 


\section{Discussion}

Prescribed burning did not have a strong effect on ant assemblages at the time of this study. It is important to note that it has been five and six years (Blocks 1 and 2, and Block 3, respectively) since prescribed burning occurred in the area and similarities among treatments may be attributed to this long fire free interval. Ant abundance per trap and species richness measures were not affected by treatment or topographic position. The exception was the evenness index, illustrating greater evenness in north-facing controls than ridge tops and burned ridge tops compared to controlled ridge tops. These differences may be due to microclimatic variation. Categorical and species specific responses are known to be a more meaningful measure of ecological implications of the effects of prescribed fire on ant assemblages (Stephens and Wagner 2006). Cold climate specialists were found more often on south-facing slopes of control than ridge tops. South-facing slopes, may be warmer and drier because they are exposed to the sun throughout the day, and hence fire intensity might be greater leading to increased tree mortality. However, no differences were found in canopy openness when comparing aspect and slope position. Furthermore, one would expect that increased sunlight where the canopy is more open would not encourage cold climate specialists to nest and forage in July. There were also increases in GM on southern facing slopes a trend that seems to follow expectations. GM and small ants also responded positively to increased canopy openness; many species in this functional group and size class nest in open soil and have been shown to increase in the presence of frequent fire (Wright 2013, unpublished data) which opens the canopy over time from tree mortality. Size classes showed no differences among treatments and topographic position. 
Some species responded to topographic position or an interaction between topographic position and treatment. The ants Formica dolosa, Pheidole dentata, Solenopsis spp. were frequently encountered on south slopes. All of these ants have been found in another site in burned areas with warmer microclimates due to open canopies (Wright 2013, unpublished data). Temnothorax pergandei, a medium sized, soil nester and CCS, was also found on south slopes although it is usually associated with closecanopy forests. On north slopes, Nylanderia faisonensis, was found frequently as this species prefers mesic habitats. On the whole, the dominant ants across all treatments and topographic positions are those that are found in mesic habitats and use wood and litter for nesting and foraging. The most dominant ant by far was Camponotus chromaiodes, and others of the genus that not only dominate in size but in numbers. Abundance of this species across treatment implies habitat homogeneity and may suggest that two prescribed fires have not substantially altered the ant habitat and resemble, from an ant's perspective a more mesic closed canopy forest.

The lack of difference in ant assemblages may demonstrate that prescribed burning that occurred 5 and 6 years ago did not have lasting effects on the structural environment important for ants (Andersen 1991, 1995, York 2000, Farji-Brener et al. 2002, Hoffman and Andersen 2003). Farji-Brener et al. (2002) compared the effects of prescribed burning in steppe and shrub habitat on ants. Steppe is characterized by simplified vegetation structure; low intensity fires did not result in distinct differences in habitat structure and, therefore, in ant assemblage composition, structure or diversity. Logan Creek and Clearwater Creek Conservation Areas have been burned only twice. Kinkead (2013) conducted research in the area in 2011 and determined that a 9.8\% 
decrease in stocking occurred 5-6 years after two prescribed burns and a $1.8 \%$ increase in vegetation cover. Seemingly, this was not enough of a shift in vegetation structure to alter ant communities. The differences that do exist seem to be a function of environmental and microclimatic factors, with some indication that slope position may affect certain species and groups. Canopy openness seems to be an indicator of groups or species that are often found in more open habitats (Coovert 2005).

\section{Management implications}

At this point in the fire regime with a fire-free interval of five years in blocks 1 and 2 and 6 years in block 3, topographic position is more influential than fire. The resulting forest succession after this fire-free interval contains little heterogeneity of ant habitat. The structural characteristics of a forest strongly affect ant behavior and ecology (Kaspari 2000) and are reflected in assemblage dynamics. Ant diversity is key to ecosystem function and a mosaic of habitats best to maintain this biological and functional diversity. The overwhelming abundance of carpenter ants (Camponotus chromaiodies, Camponotus pennsylvanicus) in both burned and unburned areas could affect the dwellings and structures of landowners that may see these ants as pests. More regular fire could reduce numbers of these ants. Ants are highly sensitive to fire (Underwood and Fisher 2006) and other habitat changes. Therefore, tracking ants may reveal subtleties in ecosystem change that go unnoticed in vegetation monitoring. 


\section{Literature Cited}

Alexander, J. D., N. E. Seavy, C. J. Ralph, and B. Hogoboom. 2006. Vegetation and topographical correlates of fire severity from two fires in the Klamath-Siskiyou region of Oregon and California. International Journal of Wildland Fire 15:237245.

Andersen, A. N. 1991. Resoinses of ground-foraging ant communities to three experimental fire regimes in a savanna forest of tropical Australia. Biotropica 23:575-585.

Andersen, A. N. 1995. A classification of Australian ant communities, based on functional group which parallel plant life-forms in relation to stress and disturbance. Journal of Biogeography 22:15-29.

Andersen, A. N. 1997. Functional groups and patterns of organization in North American ant communities: a comparison with Australia. Journal of Biogeography 24:433460 .

Andersen, A. N., A. Fisher, B. D. Hoffman, J. L. Read, and R. Richards. 2004. Use of terrestrial inverstebrates for biodiversity monitoring in Australian rangelands, with particular reference to ants. Austral Ecology 29:87-92.

Andersen, A. N., B. D. Hoffman, W. J. Muller, and A. D. Griffiths. 2002. Using ants as bioindicators in land management: simplifying assessment of ant community responses. Journal of Applied Ecology 39:8-17.

Andersen, A. N. and A. L. Yen. 1985. Immediate effects f fire on ants in the sei-arid mallee region of north-western Victoria. . Australian Journal of Ecology 10:2530.

Arthur, M. A., H. D. Alexander, D. C. Dey, C. J. Schweitzer, and D. L. Loftis. 2012. Refining the oak-fire hypothesis for manaagement of oak-dominated forests of the eastern United States. Journal of Forestry 110:257-266.

Bell, A. L. 2007. The effects of fire management on avian species in Missouri Ozark glade-woodland habitats. M.S. thesis, University of Michigan. 96p.

Blake, J. G. 2005. Effects of prescribed burning on distribution and abundance of birds in a closed-canopy oak-dominated forest, Missouri, USA. Biological Conservation 121:519-531.

Brisson, J. A., J. L. Strasburg, and A. R. Templeton. 2003. Impact of fire management on the ecology of collared lizard (Crotaphytus collaris) populations living on the Ozark Plateau. Animal Conservation 6:247-254. 
Chao, A. 1984. Nonparametric estimation of the number of classes ina population. Scandanavian Journal of Statistics 11:265-270.

Chao, A. and T. J. Shen. 2010. Program SPADE (Species Prediction and Diversity Estimation). Program and User's Guide. http://chao.stat.nthu.edu.tw. Last accessed October 12th, 2013.

Coleman, T. W. and L. K. Rieske. 2006. Arthropod response to prescription burning at the soil litter interface in oak-pine forests. Forest Ecology and Management 233:52-60.

Colwell, R. K. and J. A. Coddington. 1994. Estimaing terrestrial biodiversity through extrapolation. Philisophical Transactions of the Royal Society in London B 345:101-118.

Conover, W. J. and R. L. Iman. 1981. Rank transformations as a bridge between parametric and nonparametric statistics. The American Statistician 35:124-129.

Coovert, G. A. 2005. The Ants of Ohio (Hymenoptera: Formicidae). Ohio Biological Surver, Inc. , Columbus, $\mathrm{OH}$.

Creighton, W. S. 1950. Bulletin of the Museum of Comparative Zoology: The Ants of North America. Harvard College, Cambridge, MA.

Cutter, B. E. and R. P. Guyette. 1994. Fire frequency on an oak-hickory ridgetop in the Missouri Ozarks. American Midland Naturalist 132:393-398.

Dey, D. C. and G. W. Hartman. 2005. Returning fire to Ozark Highland forest ecosystems: effects on advance regeneration. Forest Ecology and Management 217:37-53.

Fagan, K. C., R. F. Pywell, J. M. Bullock, and R. H. Marrs. 2010. Are ants useful indicators of restoration success in temperate grasslands? . Restoration Ecology 18:373-379.

Farji-Brener, A. G., J. C. Corley, and J. Bettinelli. 2002. The effects of fire on ant communities in north-western Patagonia: the importance of habitat structure and regional context. Diversity and Distributions 8:235-243.

Fralish, J. S. 2004. The keystone role of oak and hickory in the central hardwood forest.in Upland Oak Ecology Symposium. USDA Forest Service, Asheville, NC.

Gotelli, N. J. and A. M. Ellison. 2013. A Primer of Ecological Statistics. Sinauer Associates, Inc., Sunderland, MA. 
Gotelli, N. J., A. M. Ellison, R. R. Dunn, and N. J. Sanders. 2011. Counting ants (Hymenoptera: Formicidae): biodiversity sampling and statistical analysis for myrmecologists. Myrmecological News 15:13-19.

Guyette, R. P. and B. E. Cutter. 1991. Tree-ring analysis of fire histroy of a post oak savanna in the Missouri Ozarks. Natural Areas Journal 11:93-99.

Guyette, R. P. and B. E. Cutter. 1997. Fire history, population, and calcium cycling in the Current River Watershed.in Proceedings, 11th Central Hardwood Conference; Columbia, MO. Gen. Tech. Rep. NC-188. St. Paul, MN: Department of Agriculture, Forest Service, North Central Forest Experiment Station: 354-372.

Guyette, R. P. and D. C. Dey. 2000. Humans, topography, and wildland fire: the ingredients for long-term patterns in ecosystems. Pages 28-35 in Workshop on Fire, People and the Central Hardwoods Landscape. USDA Forest Service, Richmond, KY.

Guyette, R. P., R. M. Muzika, and D. C. Dey. 2002. Dynamics of an anthropogenic fire regime. Ecosystems 5:472-486.

Guyette, R. P. and M. A. Spetich. 2003. Fire history of oak-pine forests in the lower Boston Mountains, Arkansas, USA. Forest Ecology and Management 180:463474.

Guyette, R. P., M. C. Stambaugh, and R. M. Muzika. 2006. Fire scars reveal variability and dynamics of easter fire regimes. Pages 20-39 in Fire in Eastern Oak Forests: Delivering Science to Land Managers. USDA Forest Service, Columbus, OH.

Guyette, R. P., R. M. Muzika and S. L. Voelker. 2007. The historical ecology of fire, climate, and the decline of shortleaf pine in the Missouri Ozarks. Proceedings: Shortleaf pine Restoration and Ecology in the Ozarks. Northern Research Station GTR NRS-P-15, Pages 8-18.

Hartman, G. W. and B. Heumann. 2003. Prescribed fire effects in theOzarks of Missouri: the Chilton Creek Project 1996-2001. In Proceedings of the Second International Wildland Fire Ecology and Fire Management Congress. November 16-22, 2003. Orlando, FL.

Hoffman, B. D. and A. N. Andersen. 2003. Responses of ants to disturbance in Australia, with particular reference to functional groups. Austral Ecology 28:444-464.

Hölldobler, B. and E. O. Wilson. 1990. The Ants. The Belknap Press of Harvard University Press, Cambridge, MA.

Houdeshell, H., R. L. Freidrich, and S. M. Philpott. 2011. Effects of prescribed burning on ant nesting ecology in oak savannas. American Midland Naturalist 166:98-111. 
Izhaki, I., D. J. Levey, and W. R. Silva. 2001. Effects of prescribed fire on an ant community in Florida pine savanna. Ecological Entomology 28:439-448.

Kallal, R. J. and J. S. LaPolla. 2012. Monograph of Nylanderia (Hymenoptera: Formicidae) of the World, Part II: Nylanderia in the Nearctic Zootaxa 3508:1-64.

Kaspari, M. 2000. Primer on ant ecology. Pages 9-24 in D. Agosti, J. D. Majer, L. E. Alonso, and T. R. Schultz, editors. Ants: standard methods for measuring and monitoring biodiversity Smithsonian Institute Press, Washington, D.C.

Keyser, P. D. and W. M. Ford. 2006. Influence of fire on mammals in eastern oak forest. Pages 180-190 in Fire in eastern oak forests: delivering science to land managers, proceedings of a conference. United States Department of Agriculture, Forest Service, Northern Research Station, Newtown Square, PA. Gen. Tech Report, NRS-P-1:1-XX. .

Kinkead, C. 2013. Thinning and burning in oak woodlands. Master's thesis. University of Missouri, Columbia, MO.

Kittelson, P. M., M. P. Priebe, and P. J. Graeve. 2008. Ant diversity in two southern Minnesota tallgrass prairie restoration sites. Journal of the Iowa Academy of Science 115:28-32.

Ladd, D. 1991. Reexaminaation of the role of fire in Missouri oak woodlands. Pages 6780 in Oak Woods Management Workshop, Eastern Illinois University, Charleston, IL.

Lowenstein, E. F., K. W. Grabner, and G. W. Hartman. 2002. Integrating fuel and forest management: developing prescriptions for the central hardwoods region. United States Forest Service, Columbia, MO.

MacGown, J. A. 2013. Ants (Formicidae) of the southeastern United States. http://mississippientomologicalmuseum.org.msstate.edu/Researchtaxapages/Form icidaehome.html. Last accessed October 12, 2013.

Matsuda, T., G. Turschak, C. Brehme, C. Rochester, M. Mitrovich, and R. Fisher. 2011. Effects of large-scale wildfires on ground foragin ants (Hymenoptera: Formicidae) in Southern California Environmental Entomology 40:204-216.

McCarty, K. 1998. Landscape-scale restoration in Missouri savannas and woodlands. Restoration and Management Notes 161:22-32.

McMurry, E.R. and R. M. Muzika. 2007. Initial Effects of Prescribed Burning and Thinning on Plant Communities in the Southeast Missouri Ozarks. Proceedings 15th central Hardwood Forest Conference. Northeastern Research Station GTR SRS-101, pages 241-249. 
McMurry, E. R., R. M. Muzika, E. F. Lowenstein, K. W. Grabner, and G. W. Hartman. 2007. Initial effects of prescribed burning and thinning on plant communities in the southeast Missouri Ozarks. In Buckley, D.S. and W.L. Clatterbuck (eds.). Proceedings: 15th Central Hardwood Forest Conference; 2006 February 27March 1; Knoxville, TN. Gen. Tech. Rep. SRS-101. Asheville, NC: U.S. Department of Agriculture, Forest Service, Southern Research Station: pp. 241249.

Mitrovich, M. J., T. Matsuda, K. H. Pease, and R. N. Fisher. 2010. Ants as a measure of effectiveness of habitat conservation planning in southern California. Conservation Biology 24:1239-1248.

Moranz, R. A., D. M. Debinski, L. Winkler, J. Trager, D. A. McGranahan, D. M. Engle, and J. R. Miller. 2013. Effects of grassland management practices on ant functional groups in central North America. Journal of Insect Conservation 17:699-713.

Mustafa, N. A., H. M. W. Salim, C. Fletcher, A. R. Kassim, and M. D. Potts. 2011. Taxonomic and functional diversity of ants (Hymenoptera: Formicidae) in an upper hill Dipterocarp forest in peninsular Malaysia. The Raffles Bulletin of Zoology 59:181-194.

Nelson, P. W. 2005. The Terrestrial Natural Communities of Missouri. Missouri Natural Areas Committee, Jefferson City, MO.

Nigh, T. A. 1992. The forests prior to European settlement. Pages 6-13 in A. R. P. Journet and H. G. Spratt, editors. Towards a vision for Missouri's public forests. Southeast Missouri State Unviversity, Cape Girardeau, MO.

Nigh, T. A. and W. A. Schroeder. 2002. Atlas of Missouri Ecoregions. The Missouri Department of Conservation, Jefferson City, MO.

Nowacki, G. J. and M. D. Abrams. 2008. The demise of fire and "mesophication" of forests in the eastern United States. BioScience 58:123-138.

Ottonetti, L., L. Tucci, and G. Santini. 2006. Recolonization patterns of ants in a rehabilitated lignite mine in central Italy: potential for use of Mediterranean ants as indicators of restoration processes. Restoration Ecology 14:60-66.

Pallardy, S. G., T. A. Nigh, and H. G. Garrett. 1988. Changes in forest composition in Central Missouri: 1968-1982. American Midland Naturalist 120:380-390.

Parr, C. L. and H. Gibb. 2010. Competition and the role of dominant ants. Pages 77-96 in L. Lach, C. L. Parr, and K. L. Abbott, editors. Ant Ecology. Oxford University Press, Oxford, UK. 
Phillips, R., T. F. Hutchinson, L. Brudnak, and T. Waldrop. 2007. Fire and fire surrogate treatments in mixed-oak forests: effects on herbaveous layer vegetation.in Proceedings of the conference the fire envrionment--innovations, management and policy. 26-30 March, 2007; Destin, FL. U.S. Department of Agriculture, Forest Service, Rochky Mountain Research Station. RMRS-P-46CD.

Philpott, S. M., I. Perfecto, I. Armbrecht, and C. L. Parr. 2010. Ant diversity and function in disturbed and changing habitats. Pages 137-156 in L. Lach, C. L. Parr, and K. L. Abbott, editors. Ant Ecology. Oxford University Press, Oxford, England.

Price, P. W. 2002. Species interactions and the evolution of biodiversity in C. M. Herrera and O. Pellmyr, editors. Plant-Animal Interactions: An Evolutionary Approach. Blackwell Science Oxford.

Price, P. W., R. F. Denno, M. D. Eubanks, D. L. Finke, and I. Kaplan. 2011. Insect Ecology: Behavior, Polulations and Communities. Cambridge University Press, New York.

SAS Institute Inc. 2012. What's New in SAS ® 9.3. Cary, NC: SAS Institute Inc., 2012.

Scholwater, T. D. 2011. Insect Ecology: An ecosystem approach. 3rd edition. Elesevier/Academic San Diego, CA.

Snelling, G. C. and R. R. Snelling. 2007. New synonym, new species, new keys to Neivamyrmex army ants of the United States. Pages 459-550 in R. R. Snelling, B. L. Fisher, and P. S. Ward, editors. Advances in ant systematics (Hymenoptera: Formicidae): homage to E.O. Wilson--50 years of contributions. Memoirs of the American Entomological Institute.

Spellerberg, I. 2005. Monitoring Ecological Change. Cambridge University Press, New York.

Stephens, S. and L. W. Ruth. 2005. Federal forest-fire polity in the United States. Ecological Applications 15:532-542.

Stephens, S. S. and M. R. Wagner. 2006. Using ground foraging ant (Hymenoptera: Formicidae) functional groups as bioindicators of forest health in northern Arizona ponderosa pine forests. Community and Ecosystem Ecology 35:937-949.

Strausberg, S. and W. A. Hough. 1997. The Ouachita and Ozark-St.Francis National Forests: a history of the lands and USDA Forest Service tenure. USDA Forest Service Gen. Tech. Rep. SO-121, Asheville, NC.

Taft, J. B. 2009. Effects of overstory stand density and fire on ground layer and veetation in oak woodland and savanna habitats. Pages 21-39 in 3rd Fire in Eastern oak 
forests conference; Carbondale, IL. Gen. Tech. Rep. NRS-P-46. U.S. Department of Agriculture, Forest Service, Northern Research Station.

Templeton, A. R., R. J. Robertson, J. A. Brisson, and J. L. Strasburg. 2001. Disrupting evolutionalry processes: the effect of habitat fragmentation on collared lizards in the Misouri Ozarks. Proceedings of the National Academy of Sceinces of the United States of America 98:5426-5432.

Trager, J. C., J. A. MacGown, and M. D. Trager. 2007. Revision of Nearctic endemic Formica pallidefulva group, pp. 610-636. In Snelling, R.R., B.L. Fisher, and P.S. Ward (eds). Advances in ant systematics (Hymenoptera: Formicidae): homage to E.O. Wilson - 50 years of contributions. Memoirs of the American Entomological Institute, 80 .

Underwood, E. C. and B. L. Fisher. 2006. The role of ants in conservation monitoring: If, when, and how. Biological Conservation 132:166-182.

Underwood, E. C. and J. F. Quinn. 2010. Response of ants and spiders to prescribed fire in oak woodlands of California. Journal of Insect Conservation 14:359-366.

Unstad, K. 2012. Predictors of insect diversity and abundance in a fragmented tallgrass prairie ecosystem. Master's thesis. University of Nebraska, Lincoln, NE.

Verble, R. M. 2013. Effects of fire intensity on litter arthropod communities in Ozark oak forests. Page 24. Texas Tech University.

Weatherspoon, C. P. and C. N. Skinner. 1995. An assessment of factors associated with damage to the tree crowns form the 1987 wildfires in northern California. Forest Science 41:430-451.

Wright, L. W. 2013. Ground-dwelling arthropods in burned and unburned forest in the Missouri Ozark Highlands. Unpublished raw data.

York, A. 2000. Long-term effects of frequent low-intensity burning on ant communities in coastal blackcutt forests of southeastern Australia Austral Ecology 25:83-98. 


\section{CHAPTER 4: THE POTENTIAL USE OF ANTS IN MONITORING ECOLOGICAL CHANGE AFTER PRESCRIBED BURNING IN THE MISSOURI OZARKS: SYNTHESIS AND FUTURE DIRECTIONS}

The two studies that comprise this thesis explored the effects of prescribed burning on ground-foraging ant assemblages in the Missouri Ozarks Highlands. This issue has been raised because of increased use of prescribed burning in the region (Lowenstein et al. 2002, Arthur et al. 2012) and impacts of fire on biodiversity. Groundforaging ants are biologically and functionally diverse. They influence soil structure, soil chemistry and soil biota as well as affect plant community composition. Trophically, they are important as a food source for birds, herpetofauna, small mammals, and other arthropods (Folgarait 1998, Alonso 2000, Kaspari 2000). They are sensitive to disturbance and have been show to reflect responses of other insects (Andersen et al. 2004, Andersen 2010) and patterns of community structure of other animal and plants groups (Alonso 2000, Majer et al. 2007). This chapter reviews and contrasts the two studies on ground-dwelling ant assemblages in the Missouri Ozarks and explores the further use of ants in monitoring ecological responses to disturbances like fire.

\section{Comparison of two case studies}

\section{University Forest Conservation Area (UFCA)}

Ants were collected using pitfall traps in three conservation areas in the Ozark Highlands region of southeastern Missouri in order to assess impacts of prescribed fire on ant abundance and community composition. At the UFCA ants were sampled in permanent experimental fire plots where areas had been burned annually, periodically or not at all since the late 1940s (for details see Chapter 2). Defining characteristics of the 
annually burned areas and periodically burned areas include open canopies with widely spaced fire tolerant tree species, no midstory, and a ground story layer of herbaceous forbs and graminoids. Periodically burned areas accumulated leaf litter and supported greater seedling and sapling development, particularly after 2-3 following the prescribe fire. Control areas consist of closed canopy forests with a dense midstory, and leaf litter layer with litter herbaceous ground cover and reflect the state of the majority of fire suppressed forests in the region. According to some, e.g. Faber-Langedoen (1999), Nelson (2005), NRCS (2008), this region might be best characterized as oak-hickory woodlands.

These overstory structural differences, an effect of long term prescribed fire, were accompanied by somewhat distinct ant assemblages. Ants were most abundant in annually burned plots and although these plots contained several rare species, ant communities were usually less diverse and had less evenness, owing to high abundances of a few dominant species. Small, ground nesting ants of the generalized Myrmicinae functional group dominated these areas. Species that dominate this area include Monomorium minimum, Pheidole dentata, Solenopsis spp., Nylanderia trageri, and Aphaenogaster treatae. Periodic burns supported many small cryptic, cavity/litter dwelling, species and medium sized ants, in addition to soil nesting ants. Periodically burned ant assemblages exhibited some characteristics of both annual burned plots and control plots. Species found frequently in periodically burned plots were Tapinoma sessile and the cryptic Strumigenys talpa. Periodic burns shared dominant species Solenopsis spp., Nylanderia trageri, and Aphanogaster treatae with annual burns and Aphaenogaster lamellidens, Formica pallidefulva, Myrmica pinetorum and M. 
punctiventris with control plots. Finally, controls had more medium sized ants and wood-nesting subordinate Camponotini and cold climate specialists. Ants that were dominant in these plots include Aphaenogaster carolinensis/n19 group (See chapter 2 and 3 methods for an explanation of this grouping), Camponotus chromaiodes, and Temnothorax pergandei.

Logan Creek and Clearwater Creek Conservation Areas: Joint Fires Science Project $(J F S P)$

The Logan Creek and Clearwater Creek Conservation Areas (site 2), were divided into burn and control units with a north and south facing slope and ridge plots. Areas where fire was applied were burned twice between their establishment and the time of sampling. These plots were last burned in 2005 (blocks 1 and 2) and 2006, 5-6 years prior to sampling. They were characterized by $78 \%-93 \%$ canopy cover with about 500 trees per hectare in burns and about 800 stems per hectare in controls (Kinkead 2013). A midstory has developed in both burn and control since the last fire. Burned plots support 80 per hectare of mesic species like Nyssa sylvatica, Cornus florida, and Prunus serotina, while controls contain 250 stems per hectare of these species (Kinkead 2013). Seedlings of Acer rubrum and other mesic species, have established in burned areas. The developing habitat structure following the prescribed fires resembles the control area and this is reflected in the ant community.

Data from this study suggest that 5 and 6 years (Blocks 1 and 2 and Block 3, respectively) following a prescribe fire, there were no effects on diversity, abundance, functional group, or size of ants. Nonetheless, there were differences among treatment 
types and locations. Ants dominant at both controls and burns at JFSP also dominated the control plots at UFCA including Camponotus chromaiodes, Aphaenogaster carolinensis/n=19 group, and Temnothorax pergandei. Other common ants included Camponotus americanus (in annuals and controls at UFCA), Crematogaster lineolata (found frequently in controls and periodic burns at UFCA), Camponotus pennsylvanicus. While there were more subordinate Camponotini and wood nesters in controls at UFCA, they dominated with more than $50 \%$ relative frequency of all functional groups and nesting groups in both controls and burned areas. These ant assemblage dynamics suggest that ant assemblages in both treatments at JFSP are similar to controls than burned areas at UFCA.

To confirm this trend, Morisita indices of similarity were calculated and compared using the Species Prediction and Diversity Estimation software (Chao and Shen 2010). The multiple community Morisita Similarity index (Equation.4.1) uses the sums of the probabilities that individuals selected in a bootstrap selection in a community will be a shared species among all communities or assemblages. This approach is used to predict similarity among site and communities as well as pairwise similarity with a value between 0 and 1 (Chao et al. 2008). Communities or assemblages that are more similar have a value closer to 1 whereas values of dissimilar assemblages are nearer to 0 . All burned and control plots across all treatments at both sites combined had a similarity index of 0.735 , meaning they are about $73.5 \%$ similar as a total group (Fig. 4.1). The two most similar were burns and controls at JFSP (98.6\%). The most dissimilar combination was between annual burns at UFCA and controls at JFSP (53.5\%). Control areas at UFCA and JFSP were about $80 \%$ similar. 


$$
C_{q N}=\frac{\frac{1}{\left(N^{q}-N\right)} \sum_{i=1}^{S}\left[\left(p_{i 1}+p_{i 2}+\cdots+p_{i N}\right)^{q}-\left(p_{i 1}^{q}+p_{i 2}^{q}+\cdots p_{i N}^{q}\right)\right]}{\frac{1}{N} \sum\left(p_{i 1}^{q}+p_{i 2}^{q}+\cdots p_{i N}^{q}\right)},
$$

Equation 4.1 Equation for the multiple community Morisita Similarity index (Chao et al. 2008).
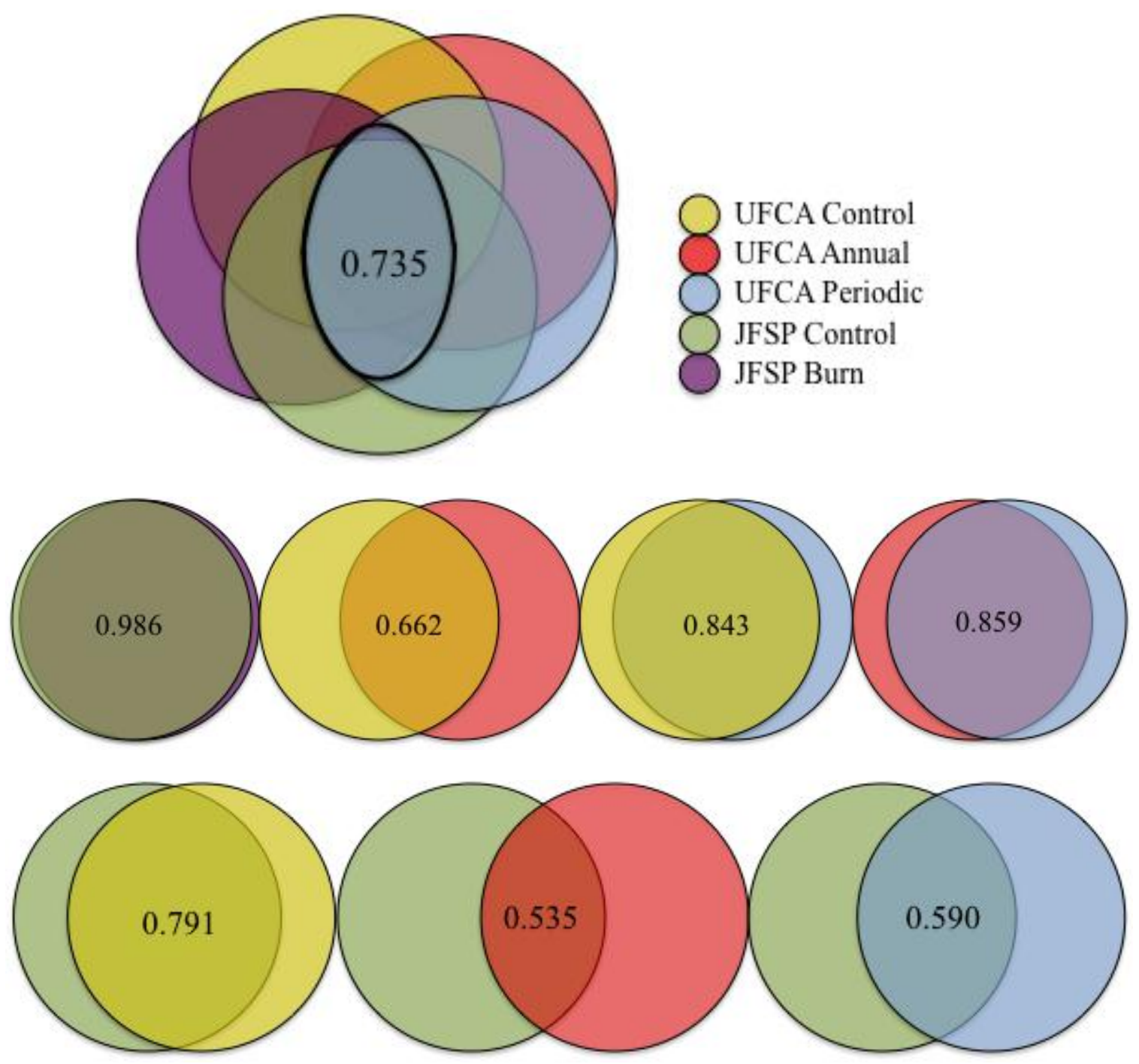


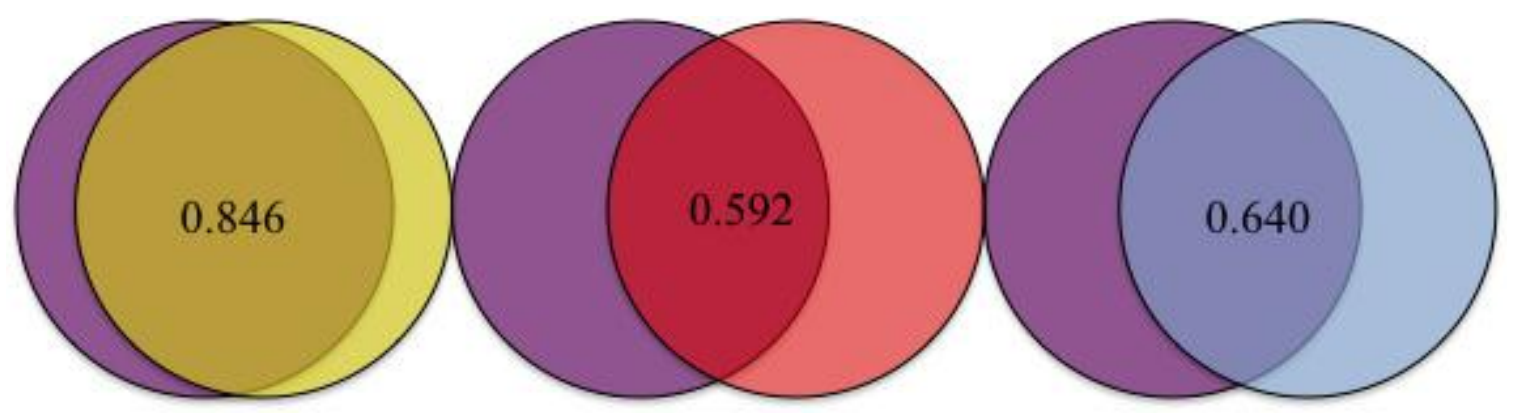

Fig. 4.1. Morisita Similarity Index between all assemblages across all treatments at sites 1 (UFCA) and 2 (JFSP) combined, ROW 1: Site 1 treatments and site 2 treatments, ROW 2: control areas at site 2 (LCCA/CCCA) compared with control (left), annually burned plots (middle) and periodically burned plots (right) at site 1 (UFCA), ROW 3: burned areas at site 2 (LCCA/CCCA) compared with control (left), annually burned plots (middle) and periodically burned plots (right) at site 1 (UFCA).

JFSP burned plots were $59.2 \%$ and $64 \%$ similar to annual and periodically burned plots in UFCA, respectively. Controls at UFCA were had a similarity index value of 59\% when compared to periodically burned plots at UFCA. UFCA's periodically burned plots were $\sim 86 \%$ similar to annually burned plots and $84 \%$ similar to controls in UFCA, showing that it has characteristics of both sites.

These comparisons show that burned areas differ within the same site, and that burned plots in JFSP were more similar to the controls at both sites than to the burned plots at UFCA. Burned areas at JFSP were 20-25\% more similar to controls than to burned areas at UFCA. UFCA burn plots structurally resemble open oak woodlands with little leaf litter, an herbaceous plant layer, and no midstory. Although, stocking levels have decreased at JFSP since the beginning of the study, before prescribed burning was applied the site more closely resembles a dry-mesic forest (Kinkead 2013). 


\section{Utility of ants in forest management in Missouri Ozarks}

The use of prescribed fire for over sixty years at UFCA shows distinct effects on ant assemblages in annually burned plots versus periodically burned plots and control plots. More ants were found in block F1 of annually burned plots both years and Shannon-diversity was highest in periodically burned plots. Assemblage composition differed due to prescribed burning treatments and so did functional and biological diversity, indication the importance of a heterogeneous mix of natural community types. However, after a fire free interval of five and six years in the respective blocks at JFSP that had only been burned twice, treatment had no distinct effects on ant community assemblage. Species richness, diversity or abundance did not vary by treatment. Functional diversity was affected more by topographic position than treatment. It is clear that ant assemblages do not differ after fire free intervals of over 5 years and that the use of regular prescribed fire to restore and maintain a variety of natural community types supports greater biological and functional diversity.

As studies in other ecological systems reveal (e.g. Izhaki et al. 2001, Hoffman and Andersen 2003, Verble and Yanoviak 2013) this research confirms that ants are sensitive to disturbance and may indicate an absence of disturbance as well. Furthermore, assessment of functional, nesting, size groups, among others, captured the more subtle ecological interactions taking place among species in a more simplified way. For example, Monomorium minimum and Pheidole dentata were the two most abundant species of ants in annual plots. Both ants are small, ground nesting generalized Myrmicinae, all groups that increased significantly in annual burns. Simplified analyses 
of ants using functional and nesting groups could make them more accessible to managers for monitoring purposes (Andersen and Hoffman 2002).

\section{Future research directions}

Continued monitoring of ant populations before and after a prescribed fire or any natural or prescribed disturbance in the Missouri Ozarks will help further knowledge of ant species present in the region and how assemblages respond to these disturbances. Documenting ant assemblages and learning of any assemblage associations with specific natural community types (e.g. oak-pine woodland, prairie, savanna) that may be restoration targets, would greatly benefit managers and ecologists alike. Prescribed fire has become more commonplace as a form of forest management and ecological restoration in recent years in the Missouri Ozarks. Incorporating ant monitoring efforts in experimental burning and silvicultural activities could shed light on more specific ecological processes that accompany these practices. Because ants directly contribute to many processes valued in forest management (e.g. seed dispersal, soil aeration for tree root growth, soil chemistry, food for other avian, mammalian and herpetofauna) and are biologically diverse, it is very important that they are considered in management practices.

To the author's knowledge, there are only two other studies similar to those described in this thesis in the Ozark region (Verble and Stephen 2009, Verble and Yanoviak 2013). These studies monitor ant responses to prescribed fire for one or two consecutive years after a disturbance. In order to understand long term ecosystem 
changes, it is recommended that monitoring occur at regular intervals (every 2-3 years) after a disturbance until an additional disturbance. Furthermore, much is unknown about Missouri ant fauna, therefore additional studies provide basic information on these taxa and could result in new state records and possibly species new to science in the Ozark biogeographic region - an area known for high endemism (Nelson 2005). Continued use of the functional group model from Australia (Andersen 1995, 1997) is suggested in order to examine ecological and biogeographical patterns at a coarser scale. However, a functional group scheme that more directly addresses fine scale ecological change should be developed in order to answer site-specific questions about ecosystem change. 


\section{Literature cited}

Alonso, L. E. 2000. Ants as indicators of diversity. Pages 80-88 in D. Agosti, J. D. Majer, L. E. Alonso, and T. R. Schultz, editors. Ants: Standard Methods for Measuring and Monitoring Biodiversity. Smithsonian Institution, Washington, D.C.

Andersen, A. N. 1995. A classification of Australian ant communities, based on functional group which parallel plant life-forms in relation to stress and disturbance. Journal of Biogeography 22:15-29.

Andersen, A. N. 1997. Functional groups and patterns of organization in North American ant communities: a comparison with Australia. Journal of Biogeography 24:433460.

Andersen, A. N. 2010. Functional groups in ant community ecology Pages 142-144 in L. Lach, C. L. Parr, and K. L. Abbott, editors. Ant Ecology. Oxford University Press, Oxford, England.

Andersen, A. N., B. D. Hoffman, W. J. Muller, and A. D. Griffiths. 2002. Using ants as bioindicators in land management: simplifying assessment of ant community responses. Journal of Applied Ecology 39:8-17.

Andersen, A. N., A. Fisher, B. D. Hoffman, J. L. Read, and R. Richards. 2004. Use of terrestrial inverstebrates for biodiversity monitoring in Australian rangelands, with particular reference to ants. Austral Ecology 29:87-92.

Arthur, M. A., H. D. Alexander, D. C. Dey, C. J. Schweitzer, and D. L. Loftis. 2012. Refining the oak-fire hypothesis for manaagement of oak-dominated forests of the eastern United States. Journal of Forestry 110:257-266.

Chao, A., L. Jost, S. C. Chiang, Y. H. Jiang, and R. Chazdon. 2008. A two-stage probabalistic approach to multiple-community similarity indices. Biometrics 64:1178-1186.

Chao, A. and T. J. Shen. 2010. Program SPADE (Species Prediction and Diversity Estimation). Program and User's Guide. http://chao.stat.nthu.edu.tw. Last accessed October 12th, 2013.

Faber-Langednoen, D., editor. 1999. International classification of ecological communities: terrestrial vegetation of the Midwestern U.S. The Nature Conservancy, Midwest Conservation Science Department, Minneaopolis, MN.

Folgarait, P. J. 1998. Ant diversity and its relationship to ecosystem functioning: a review. Biodiversity and Conservation 7:1221-1244. 
Izhaki, I., D. J. Levey, and W. R. Silva. 2001. Effects of prescribed fire on an ant community in Florida pine savanna. Ecological Entomology 28:439-448.

Kaspari, M. 2000. Primer on ant ecology. Pages 9-24 in D. Agosti, J. D. Majer, L. E. Alonso, and T. R. Schultz, editors. Ants: standard methods for measuring and monitoring biodiversity Smithsonian Institute Press, Washington, D.C.

Kinkead, C. 2013. Thinning and burning in oak woodlands. Master's thesis. University of Missouri, Columbia, MO.

Lowenstein, E. F., K. W. Grabner, and G. W. Hartman. 2002. Integrating fuel and forest management: developing prescriptions for the central hardwoods region. United States Forest Service, Columbia, MO.

Majer, J. D., G. Orabi, and L. Bisevac. 2007. Ants (Hymenoptera: Formicidae) pass the bioindicator scorecard. Myrmecological News 10:69-76.

Nelson, P. W. 2005. The Terrestrial Natural Communities of Missouri. Missouri Natural Areas Committee, Jefferson City, MO.

Natural Resource Conservation Service (NRCS). 2008. Open woodland information sheet: conservation practive information sheet (IS-MO643w). Available online at http://www.forestandwoodland.org/pdfs/woodland information sheet.pdf. Last accessed November 10, 2013.

Verble, R. M. 2013. Effects of fire intensity on litter arthropod communities in Ozark oak forests. Page 24. Texas Tech University.

Verble, R. M. and F. M. Stephen. 2009. Occurrence of carpenter ants in Ozark forests in relation to prescribed fire and stand variables. Journal of Forestry 33:42-45.

Verble, R. M. and S. P. Yanoviak. 2013. Short-term effects of prescribed burning on ant (Hymenoptera: Formicidae) assemblages in Ozark forests. Annals of the Entomological Society of America 106:198-203. 